\title{
Chemical Quality of
}

Surface Waters in

Devils Lake Basin

North Dakota

GEOLOGICAL SURVEY WATER-SUPPLY PAPRR 1295

Prepared as part of the program of the Department of the Interior for development of the Missouri River basin

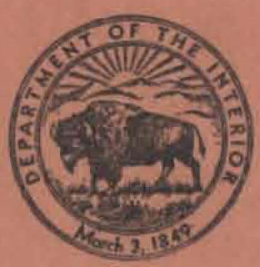





\section{Chemical Quality of}

Surface Waters in

Devils Lake Basin

North Dakota

By H. A. SWENSON and B. R. COLBY

GEOLOGICAL SURVEY WATER-SUPPLY PAPER 1295

Prepared as part of the program of the Department of the Interior for development of the Missouri River basin

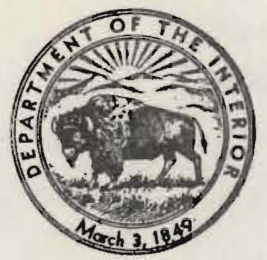


UNITED STATES DEPARTMENT OF THE INTERIOR

Douglas McKay, Secretary

GEOLOGICAL SURVEY

W. E. Wrather, Director

For sale by the Superintendent of Documents, U. S. Government Printing Office Washington 25, D. C. - Price 75 cents (paper cover) 


\section{CONTENTS}

Pago

Abstract

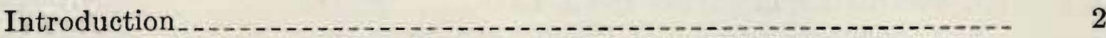

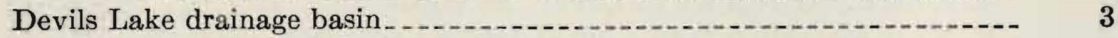

Physiography and drainage..... 5

Climate _...... 5

Transportation_-

Recreation

Fluctuations of Devils Lake

Hydrology

Chemical and physical properties of the lake waters._...... 24

Preliminary considerations........... 24

Sweetwater group of lakes._._. 27

Mauvais Coulee...... 28

Silver Lake........... 28

Devils Lake_........ 30

The period 1948 to 1952

Sixmile Bay _.............. 40

East Bay Devils Lake____ 40

Mission Bay ........... 43

East Devils Lake_..... 43

Western Stump Lake_._._._._._. 45

Eastern Stump Lake__._.

Miscellaneous lakes.......... 50

Sheyenne River

Concentrations and tonnages of dissolved solids in lake waters._._.... $\quad 52$

Devils Lake

East Bay Devils Lake_._. 65

East Devils Lake_......... 68

Stump Lake_............... 70

Discharge into the Sheyenne River.-_-_._. 73

Effect of changes in assumptions

Pollution problems of lake restoration

Literature cited.

Index $\ldots$

\section{ILLUSTRATIONS}

Page

Plate 1. Map of Devils Lake area, North Dakota ......... Inside back cover

2. Mauvais Coulee, view upstream from U. S. Highway 2 near Churchs Ferry

3. Elevation marker at narrows on State Route 57 showing pre-

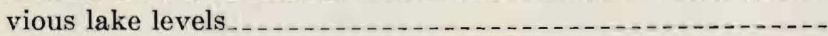

4. Incrustations on large boulder along west bank of East Devils Lake, 1949 
Figure 1. Monthly average temperature during a 48-year period and monthly departures from average during a 4-year period ending September 30, 1952

2. Cumulative precipitation at Devils Lake by water years for 4-year period ending September 30, 1952, and the average for 77 years

3. Fluctuation in level of Devils Lake

4. Annual precipitation at Devils Lake, 1870-1952 . . . .

5. Mean monthly precipitation at Devils Lake, 1870-1952 - ...-

6. Annual runoff of the Sheyenne River at Sheyenne and West Fargo ...

7. Annual runoff of the Sheyenne River above Sheyenne compared with temperature at Devils Lake and annual precipitation at Maddock

8. Runoff, for water years $1930-52$, of Sheyenne River upstream from Sheyenne versus annual precipitation and annual aver-

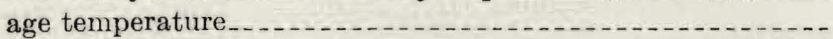

9. Area and capacity curves for Devils Lake west of State Route 20

10. Computed annual inflow to Devils Lake and significant climatological factors

11. Schematic map of lakes and drainage areas in the Devils Lake basin

12. Map of Devils Lake showing areal concentration of salts in parts per million, June 14-18, $1949 \ldots \ldots$.................

13. Effects of fluctuation in stage on chemical character of water in Devils Lake, 1948-52

14. Map of East Devils Lake showing areal concentration of salts in parts per million, June 18, 1949.

15. Map of Stump Lake showing areal concentration of salts in parts per million, June 16, $1949 \ldots$

16. Area and capacity curves for East Bay Devils Lake._.......

17. Area and capacity curves for East Devils Lake.............

18. Area and capacity curves for west Stump Lake............

19. Area and capacity curves for east Stump Lake...........

20. Volume of water and tonnage of dissolved solids in Devils Lake

21. Computed progressive decrease in concentrations of dissolved solids in Devils Lake after filling to 1,425 fe st.............

22. Computed progressive decrease in concentrations of dissolved solids in East Bay Devils Lake after filling to 1,425 feet...-

23. Computed progressive decrease in concentrations of dissolved solids in East Devils Lake after filling to 1,425 feet........-

24. Computed progressive decrease in concentrations of dissolved solids in Stump Lake after filling to 1,425 feet.............

\section{TABLES}

TABLE 1. Reported maximum and minimum observed altitudes of Devils Lake_...

2. Estimated inflow to Devils Lake by years, 1930-52 . . . . . . . 
TABLE 3. Chemical analyses of miscellaneous surface-water samples in Devils Lake basin, June 17-20, 1949

4. Sampling data for miscellaneous lake and surface waters, Devils Lake basin

5. Chemical analyses of water samples from Mauvais Coulee near Churchs Ferry.

6. Chemical analyses of water in Devils Lake

7. Chemical analyses of water in Sixmile and Mission Bays.....-

8. Chemical analyses of water in East Devils Lake and west and east Stump Lake

9. Chemical analyses of water in Cranberry Lake

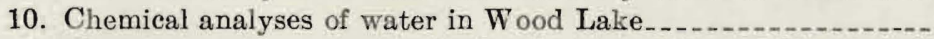

11. Chemical analyses of water in the Sheyenne River at Sheyenne.-

12. Chemical analyses of water in the Sheyenne River near Warwick

13. Chemical analyses of water at miscellaneous stations in the Sheyenne River and the Red River of the North...........

14. Approximate volumes of water and tonnages of dissolved solids in Devils Lake, 1899-1952.

15. Summary of computations for Devils Lake and adjoining lakes of local annual inflow, net evaporation, dissolved solids, and water and years required to fill to an altitude of 1,425 feet_.

16. Approximate volumes of water and tonnages of dissolved solids in East Bay Devils Lake

17. Approximate volumes of water and tonnages of dissolved solids in East Devils Lake.

18. Approximate volumes of water and tonnages of dissolved solids in Stump Lake

19. Computations of water necessary during the first year of outflow to dilute the discharge from Stump Lake.............. 


\title{
GHEMIGAL QUALITY OF SURFAGE WATERS IN DEVILS LAKE BASIN, NORTH DAKOTA
}

\author{
By H. A. Swenson and B. R. Colby
}

\section{ABSTRACT}

Devils Lake basin, a elosed basin in northeastern North Dakota, covers about 3,900 square miles of land, the topography of which is morainal and of glacial origin. In this basin lies a chain of waterways, which begins with the Sweetwater group and extends successively through Mauvais Coulee, Devils Lake, East Bay Devils Lake, and East Devils Lake, to Stump Lake. In former years when lake levels were high, Mauvais Coulee drained the Sweetwater group and discharged considerable water into Devils Lake. Converging coulees also transported excess water to Stump Lake. For at least 70 years prior to 1941, Mauvais Coulee flowed only intermittently, and the levels of major lakes in this region gradually declined. Devils Lake, for example, covered an area of about 90,000 acres in 1867 but had shrunk to approximately 6,500 acres by 1941 .

Plans to restore the recreational appeal of Devils Lake propose the dilution and eventual displacement of the brackish lake water by fresh water that would be diverted from the Missouri River. Freshening of the lake water would permit restocking Devils Lake with fish.

Devils and Stump Lake have irregular outlines and numerous windings and have been described as lying in the valley of a preglacial river, the main stem and - tributaries of which are partly filled with drift. Prominent morainal hills along the south shore of Devils Lake eontrast sharply with level farmland to the north.

The mean annual temperature of Devils Lake basin ranges between $36^{\circ}$ and $42^{\circ} \mathrm{F}$. Summer temperatures above $100^{\circ} \mathrm{F}$ and winter temperatures below $-30^{\circ} \mathrm{F}$ are not uncommon. The annual precipitation for 77 years at the city of Devils Lake averaged 17.5 inches. Usually, from 75 to 80 percent of the precipitation in the basin falls during the growing season, April to September.

From 1867 to 1941 the net fall of the water surface of Devils Lake was about 38 feet. By 1951 the surface had risen fully 14 feet from its lowest altitude, 1,400.9 feet. Since 1951, the level has fallen slowly. Hydrologic changes that may have caused Devils Lake to alter from a very large, moderately deep lake of fresh water to a small, shallow body of brackish water are discussed and evaluated on the basis of scanty information. During several years of average precipitation, temperature, and evaporation, Devils Lake and lakes upstream should receive nearly a quarter of an inch of runoff annually from the drainage area of about 3,000 square miles. Approximately 55 square miles of tributary area would be required to maintain each square mile of lake surface. However, runoff, expressed as percentage of the average, differs greatly from year to year. The amount of runoff retained in upstream lakes also varies greatly. For these two reasons, annual inflow to Devils Lake is extremely variable.

Because many waterways in this basin have no surface outlets at normal stages, runoff collects in depressions, is concentrated by evaporation, and forms saline or alkaline lakes. The chemical and physical properties of the lake waters vary chiefly with changes in lake stage and volume of inflow. Scattered records from 1899 to 1923 and more comprehensive data from 1948 to 1952 show a range of salt concentration from 6,130 to 25,000 parts per million (ppm) in the water of 
Devils Lake. Although concentration has varied, the chemical composition of the dissolved solids has not changed appreciably. Lake waters are more concentrated in the lower part of the basin, downstream from Devils Lake. For periods of record the salt concentration ranged from 14,932 to $62,000 \mathrm{ppm}$ in East Devils Lake and from 19,000 to 106,000 ppm in east Stump Lake.

Current and past tonnages of dissolved solids in Devils Lake, East Bay Devils Lake, East Devils Lake, and east and west Stump Lakes were computed from concentrations and from altitude-capacity curves for each lake. Neither the average rate of diversion of water to restore Devils Lake to a higher level nor the quality of the diverted water is definitely known; consequently, three difierent assumptions of rates of diversion to Devils Lake and concentrations of dissolved solids in the diverted water were made to estimate concentrations in the restored lakes. Quantities of salts that might be redissolved as lake water is replenished, natural inflow, and evaporation from the lakes were all computed or estimated. Probable minimum and maximum concentrations of dissolved solids were computed for each lake on the basis of restoration of lake level to 1,425 feet. Computed probable minimum and maximum concentrations when the lakes first reach this elevation are 3,600 and $4,600 \mathrm{ppm}$ for Devils Lake and 10,500 and $15,800 \mathrm{ppm}$ for Stump Lake. Computed concentrations to be eventually reached are 600 to $1,050 \mathrm{ppm}$ for Devils Lake and 690 to $1,500 \mathrm{ppm}$ for Stump Lake. The dissolved solids in all the lakes might total as much as 8 million tons but probably not less than 5.4 million tons by the time the last of these lakes had been raised to 1,425 feet but before water was released into the Sheyenne River. Curves applicable only if the lakes do not become stratified (vertical mixing incomplete) were prepared to indicate the rate of dilution in each lake for the three different assumptions of diverted inflow to Devils Lake. The eurves show, too, the concentration of dissolved solids in the outflow from each lake; for Stump Lake the curves indicate the concentration of dissolved solids of outflow to the Sheyenne River. Also computed were the large quantities of water required in the Sheyenne River to dilute to tolerable concentrations the first year of outflow from Stump Lake.

\section{INTRODUCTION}

For many years the decline in level of Devils Lake in northeastern North Dakota has been a matter of concern. This lake, the largest in North Dakota, was once the principal attraction of the most popular resort area in the State. In 1867 Devils Lake included several bays that have since dried up or become detached lakes. At that time the total lake surface covered about 90,000 acres, but by 1940 the lake had shrunk to a shallow body of stagnant, brackish water covering 6,500 acres (North Dakota, 1944, p. 23). Where pike and other edible fish had once abounded, neither food nor game fish has existed for many years.

A plan of the Department of the Interior for the conservation, control, and use of water resources in the Missouri River Basin has been described in United States Senate Document 191 (1944). Included in the contemplated utilization of the basin waters to stabilize agriculture and the general economy are proposals to restore Devils Lake to a higher level by diversion of Missouri River water. The proposed diversion from the Missouri River to Devils Lake would 
not be direct, and the quality of the water that eventually might reach Devils Lake would be lowered by use for irrigation and by evaporation in reservoirs. These proposals were subsequently altered to contemplate diversion of water from Garrison Reservoir, at present under construction (U. S. Bur. of Reclamation, 1953).

Prompted by the earlier tentative proposals, the Geological Survey in late 1948 began a study of quality-of-water problems in the Devils Lake area. Obviously, the preliminary planning for reviving the recreational use of Devils Lake requires certain hydrologic information. This information includes: the present salt concentration and properties of the lake waters, the extent to which the salinity of the waters could be reduced by inflow of fresh water from outside the basin, the volume of inflow and outflow that would be required to maintain tolerable salt concentrations, and properties of the inflow water.

This report summarizes the investigations by the Geological Survey of the quality of water in the Devils Lake basin from November 1948 to December 1952. The study was made under the general direction of S. K. Love and under the immediate supervision of P. C. Benedict. Records of lake levels for Devils Lake and unpublished streamflow measurements for Mauvais Coulee were furnished by H. M. Erskine.

Acknowledgments are made to H. F. Mosbaugh, Chairman, Interior Missouri Basin Field Committee, and R. L. Bagwell, of the U. S. Fish and Wildlife Service, for their cooperation and assistance during the investigation. Many residents of the city of Devils Lake offered helpful information concerning lakes in the region and otherwise assisted in the study. C. M. Gonser furnished information on early lake history, and E. A. Thompson provided a boat and outboard motor for the collection of many water samples. G. A. Abbott, of the University of North Dakota, made helpful contributions and suggestions concerning the chemistry of Devils Lake water.

A progress report released to the open files during October 1950 under the title, "Chemical character of surface waters in the Devils Lake basin, North Dakota," summarized results that were obtained from the beginning of the investigation to the end of June 1949.

The present report includes the basic data in the progress report and other data not previously released.

\section{DEVILS LAKE DRAINAGE BASIN}

Devils Lake basin, a large closed drainage area in northeastern North Dakota, extends from the southern slopes of the Turtle Mountains and the Canadian boundary to a series of prominent hills that lie between Devils Lake and the Sheyenne River. (See pl. 1.) In 
describing the extent of the basin, Simpson (1929, p. 9) points out that although the eastern and western boundaries are indistinct, the area of the entire basin was estimated as about 3,500 square miles. According to the U. S. Geological Survey (1952), the area in the closed basin is 3,940 square miles. However, only about 3,000 square miles of this area is tributary to Devils Lake; nearly 1,000 square miles is tributary to East Devils and Stump Lakes. Devils Lake and the smaller adjacent lakes comprise only a small fraction of Devils Lake drainage basin. The city of Devils Lake is about 3 miles north of the nearest shore of the lake. Lakota, in Nelson County, and Minnewaukan, in Benson County, are important towns in the basin.

The city of Devils Lake, the county seat of Ramsey County, was formerly a tourist center but is now an agricultural and trading community.

Prior to the general decline in lake levels in this region, Mauvais Coulee drained the Sweetwater group of lakes and discharged considerable water into Devils Lake; several converging coulees transported excess water to Stump Lake in the lower end of the basin. During the decline in lake levels, flow in Mauvais Coulee has been intermittent and largely in response to spring snowmelt or excessive precipitation. In 1949 and 1950 Mauvais Coulee, the largest drainage line in the system, had substantial flow (pl. 2).

The inflow of surface runoff to Devils Lake from marginal lands is small and very irregular. Simpson $(1912$, p. 115) stated that comparatively little flow entered the lake as surface inflow from marginal lands because of the morainal character of the topography; he mentioned the many undrained depressions that are common in the adjacent hills and prairies. However, Simpson may have underestimated the runoff from the area, as considerable drainage enters the lake along the northwest part of West Bay.

Both Devils and Stump Lakes probably receive some ground-water inflow from the glacial drift of the large drainage basin. Ground water moves slowly downslope from the north through the lower sandy lenses of the drift that overlies the Pierre shale.

The Devils Lake-Stump Lake chain of lakes has no surface outlet below an altitude of about 1,460 feet and lies in a closed basin. Since the beginning of recorded observations, the escape of water from the lakes probably has been entirely or almost entirely by evaporation. Outflow in the form of ground water is unlikely, because the groundwater level around the lakes is generally higher than the lake surfaces and because the lakebeds seem to be nearly impermeable. Many years ago Stump Lake overflowed into the Sheyenne River near the present town of Tolna. 


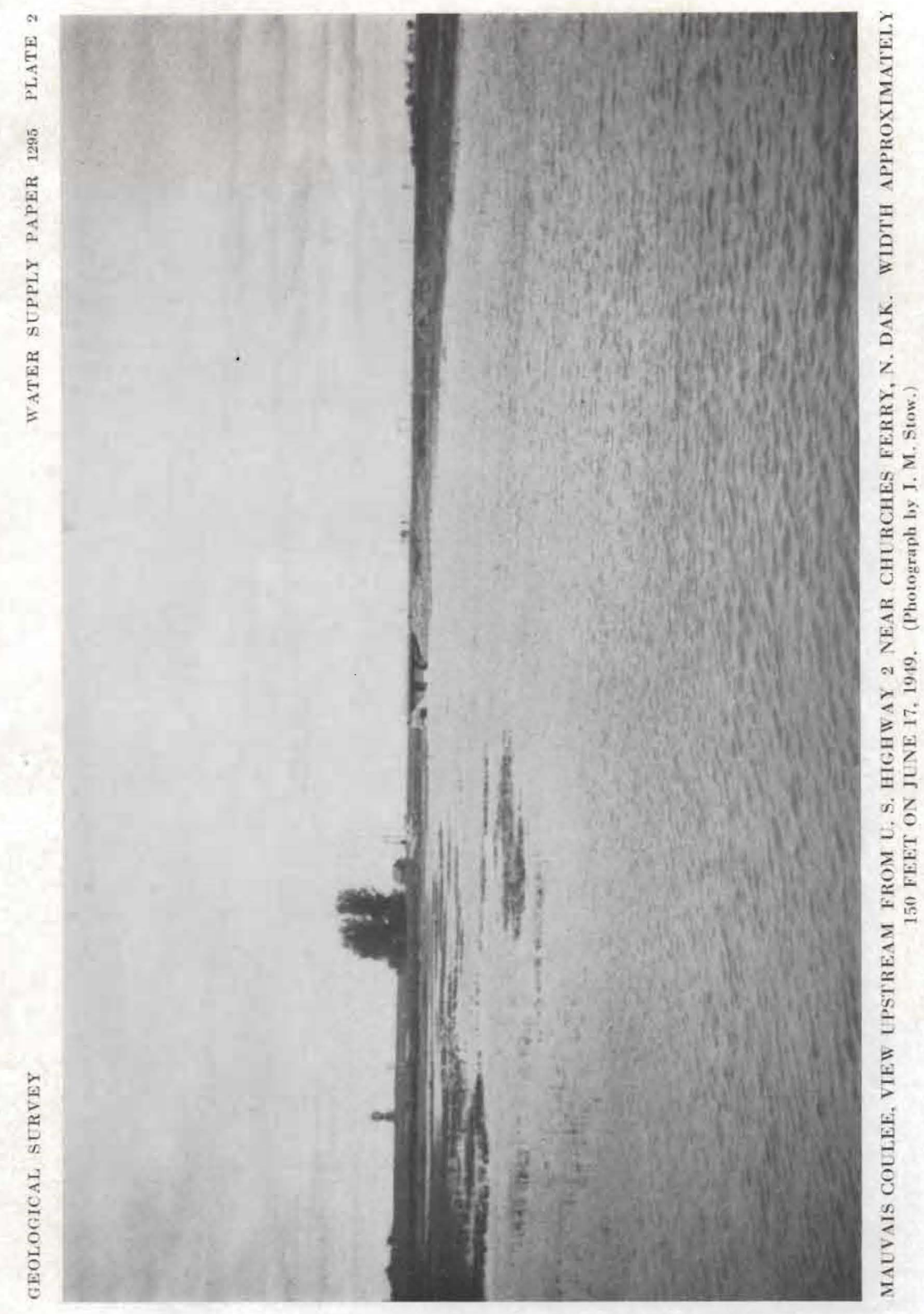




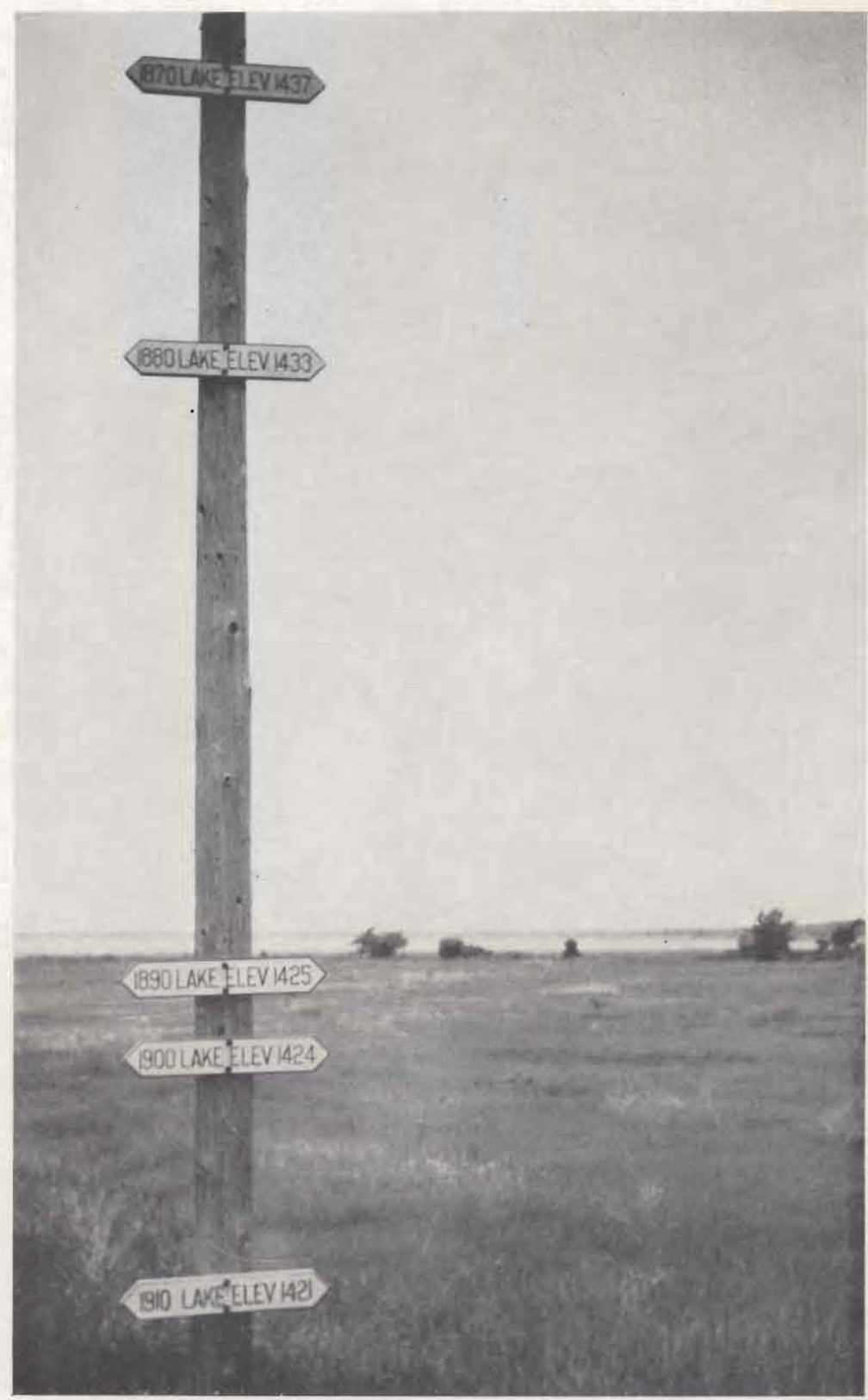

ELEVATION MARKER AT NARROWS ON STATE ROUTE 57 SHOWING PREVIOUS LAKE LEVELS. DEVII.S L.AKE, IN BACKGROUND, 1949. (Photograph by J. M. Stow.) 


\section{PHYSIOGRAPHY AND DRAINAGE}

The topographic forms and the basin itself are of glacial origin. The drainage channels are imperfectly developed because the gradients are slight, the land surface is irregular, and the runoff is low. Kettle holes and other shallow depressions dot the landscape and in the spring are partly filled with water. Devils and Stump Lakes have irregular outlines and long bays or arms and are considered by Upham (1895, p. 170-171) to lie in the valley of a preglacial river, which, with its tributaries, is partly filled with drift. Along the south shore of Devils Lake is an unbroken ridge of prominent and typical morainal hills that are in strong contrast to the level farmland north of the lake. As Devils Lake receded, several smaller lakes formed; springs feeding some of these smaller lakes help to keep them fresh. The physiography of the Devils and Stump Lakes region has been thoroughly discussed by Simpson (1912, p. 105-157).

\section{CLIMATE}

The mean annual temperature of Devils Lake basin ranges between $36^{\circ}$ and $42^{\circ} \mathrm{F}$. Maximum and minimum temperatures of above $100^{\circ} \mathrm{F}$ and below $-30^{\circ} \mathrm{F}$ are not unusual. January, with mean temperatures slightly above zero, is the coldest month. July is the warmest month; the mean temperature is about $67^{\circ} \mathrm{F}$, and August is only about $2^{\circ}$ cooler. The monthly mean temperatures by years at the U. S. Weather Bureau Station in the city of Devils Lake are shown in figure 1 for the 4-year period ending September 30, 1952. The average temperatures by months for the 48-year period of record are also shown.

Most of the precipitation occurs during the summer months, generally as thunderstorms of cloudburst intensities. In most years some part of the basin receives a rainfall of as much as 2 to 3 inches in 24 hours, and from 5 to 6 inches of rainfall in 24 hours has been measured. At the city of Devils Lake the annual precipitation for 77 years $(1870-90,1897-1952)$ averaged (17.5 inches. Usually, from 75 to 80 percent of the average annual precipitation falls during the growing season, April to September. Almost 50 percent falls during the 3-month period-May, June, and July. The average precipitation for the driest months-November, December, January, and February-is about 0.5 inch each. (See fig. 2.)

The average annual snowfall is slightly more than 30 inches. Although first light snow may fall in September, usually very little snow falls even in October. The greatest amount of snow falls during March, and light snows often occur during May. 


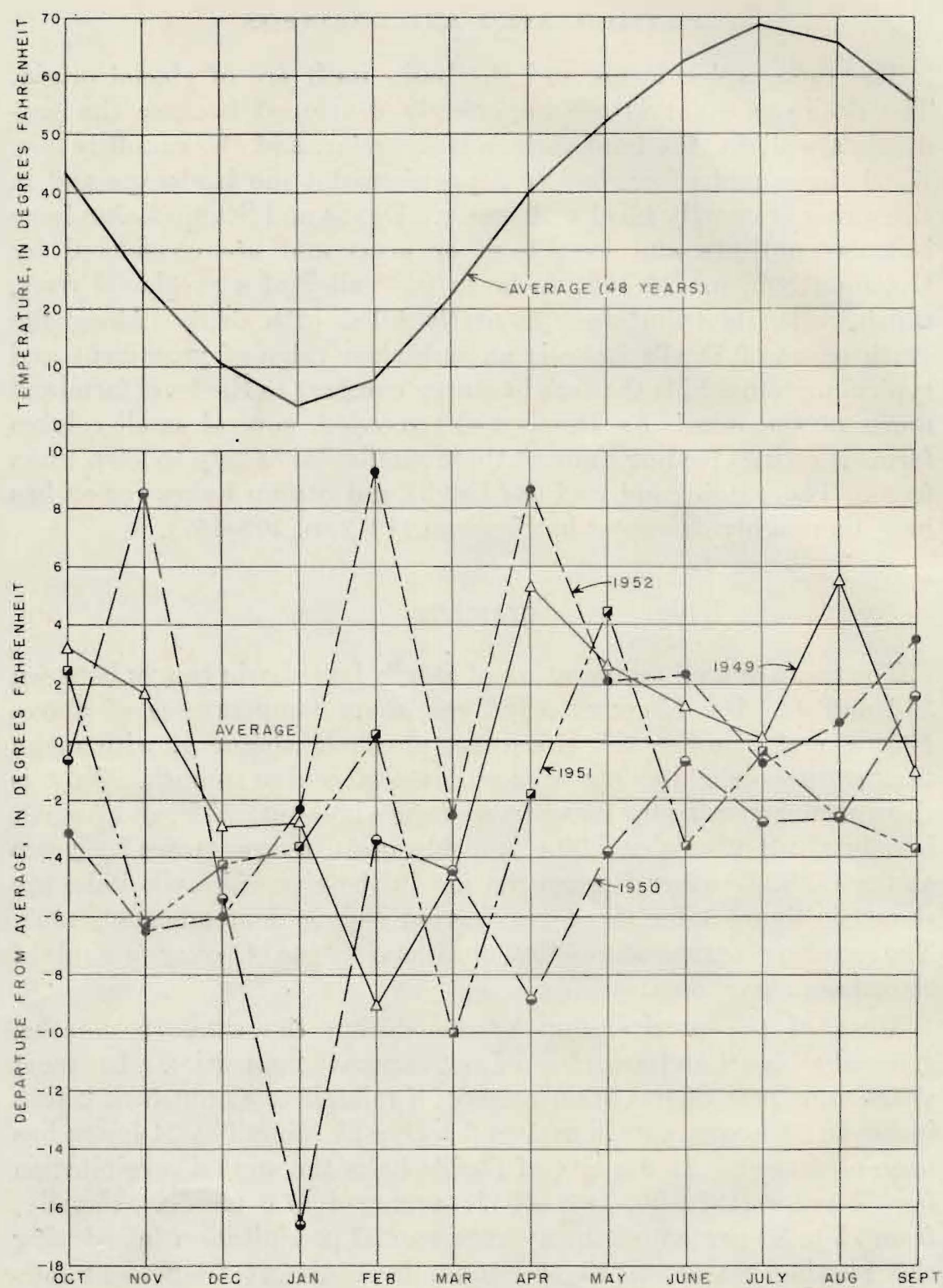

FigURE 1.-Monthly average temperature during a 48-year period and monthly departures from average during a 4-year period ending September 30, 1052.

During all months of the year the prevailing wind is from the northwest. Southerly winds occur more often during the summer than during the winter. The average annual wind velocity for the basin is about 10 miles per hour, and the wind movement is greatest in the spring and least during August. 


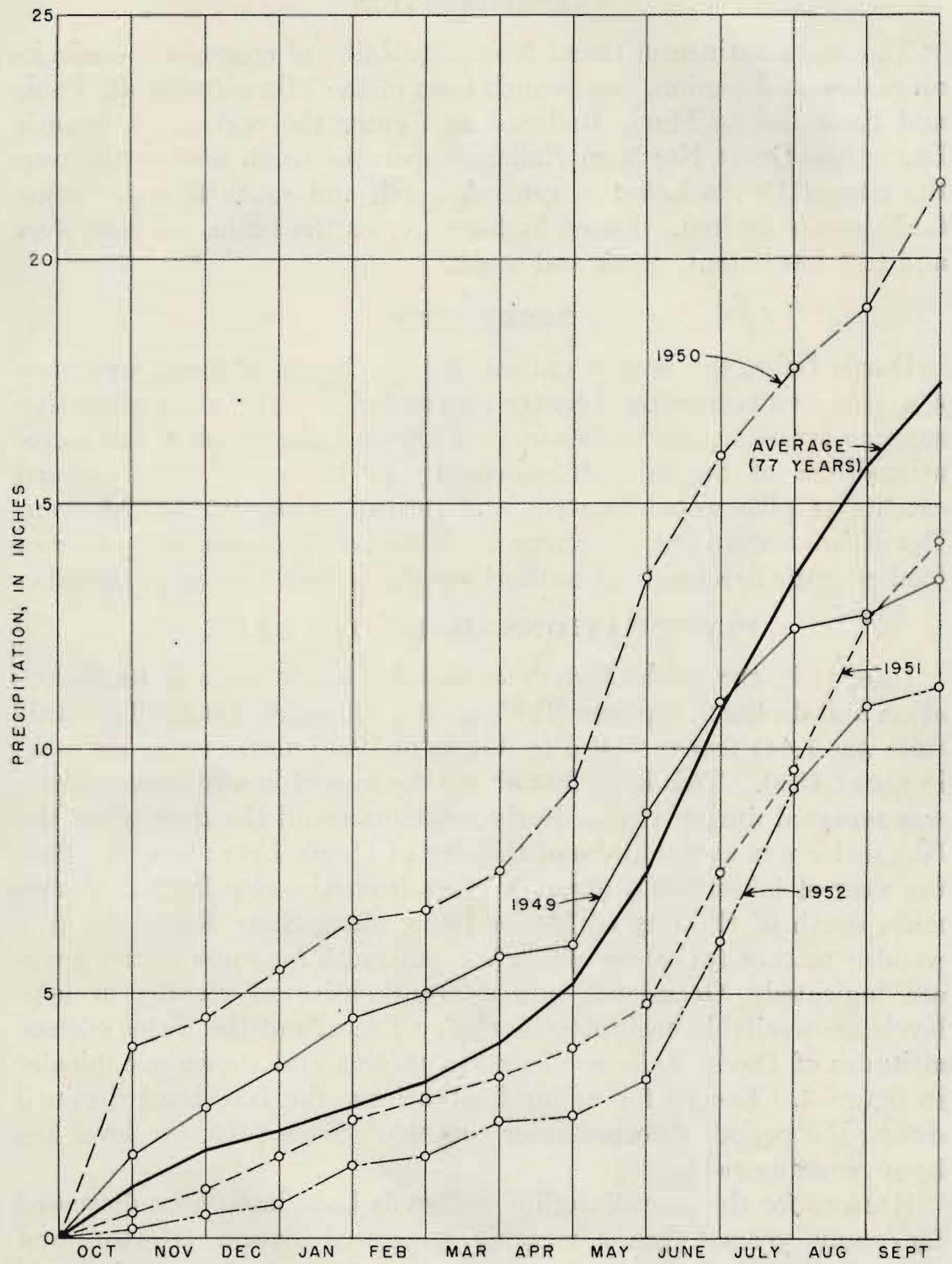

FIgURE 2.-Cumulative precipitation at Devils Lake by water years for 4-year period ending September 30,1952 , and the average for 77 years.

The relative humidity averages nearly 78 percent throughout the basin, however, it is frequently very low during the summer--at times below 25 percent. 
TRANSPORTATION

The transcontinental Great Northern Railroad crosses the basin in an east-west direction, and branch lines of the Minneapolis, St. Paul, and Sault Sainte Marie Railroad also enter the region. A branch line of the Great Northern Railroad operates north and south from the city of Devils Lake; in general, north and south transportation facilities are limited. Paved bighways cross the basin east and west and to a less extent, north and south.

\section{RECREATION}

Devils Lake, the largest natural lake in North Dakota, was once a well-known recreational center and considered the most attractive summer resort site in the State. As Devils Lake receded, the recreational use of the lake deteriorated. In the early 1880's record catches of pike were reported, and carload shipments of fish from Devils Lake were not uncommon. For over 60 years no species of food or game fish has been authoritatively reported to be in the lake.

\section{FLUCTUATIONS OF DEVILS LAKE}

Interest in the recent history of Devils Lake centers in its fluctuation and decline. Upham (1895, p. 595) thought that the lake altitude was 1,441 feet (reduced to datum of 1929) above mean sea level in about 1830. This is 40 feet above the lowest known stage, which was reported during 1940. Early residents recall the time when the lake water was at the limits of the city of Devils Lake; now, in 1953, the nearest lakeshore is about 3 miles from the city limits. A few miles south of the city of Devils Lake, along State Route 57, is a wooden marker (pl. 3) on which lake altitudes for some earlier years are indicated. Occasional but well-authenticated records of lake levels are available beginning in 1867 . Records of the water surface altitudes of Devils Lake are listed in table 1 and shown graphically in figure 3. Except for minor fluctuations, the lake level declined during the period of record prior to 1940 . Since 1940, the level has been generally rising.

Reasons for the overall decline of Devils Lake have been discussed for many years. One commonly suggested reason (Horton and others, 1910; U. S. Public Healtb Service, 1952) is that the increase in tillage of farmland in the region has decreased the runoff from the area tributary to the lake; however, no tenable relationship has been definitely established. Another reason frequently mentioned is that the general lowering of the water table has caused the lake level to fall. The water table probably has fluctuated somewhat in accordance with the changes in lake level, because changes in runoff have affected both surface-water and ground-water altitudes. Perhaps 
TABLE 1.-Reported maximum and minimum observed altitudes of Devils Lake

[Referred to datum of 1929]

\begin{tabular}{|c|c|c|c|c|c|}
\hline Year & Maximum & Minimum & Year & Maximum & Minimum \\
\hline $\begin{array}{l}1867= \\
1879=- \\
1883=- \\
1887=- \\
1890=\end{array}$ & \multicolumn{2}{|c|}{$\begin{array}{r}11,438.3 \\
1,434.6 \\
1,434.4 \\
1,427.0 \\
1,424.6\end{array}$} & $\begin{array}{l}1924 \\
1925 \\
1926 \\
1927- \\
1928\end{array}$ & \multicolumn{2}{|c|}{$\begin{array}{l}1,416.2 \\
1,414.8 \\
1,413.7 \\
1,413.6 \\
1,412.8\end{array}$} \\
\hline $\begin{array}{l}1896 \\
1901- \\
1902- \\
1903- \\
1904\end{array}$ & $\begin{array}{r}1,4 \\
1,424.0 \\
1,425.8 \\
1,424.8 \\
1,425.0\end{array}$ & $\begin{array}{l}6 \\
1,423.2 \\
1,424.6 \\
1,423.4 \\
1,424.2\end{array}$ & $\begin{array}{l}1929 \\
1930- \\
1931- \\
1932 \\
1933\end{array}$ & $\begin{array}{l}1,412.2 \\
1,411.4 \\
1,411.4 \\
1,410.9 \\
1,410.2\end{array}$ & $\begin{array}{l}1,411.3 \\
1,411.0 \\
1,410.0 \\
1,409.4 \\
1,408.2\end{array}$ \\
\hline $\begin{array}{l}1905- \\
1906=- \\
1907- \\
1908 \\
1909 .\end{array}$ & $\begin{array}{l}1,425.2 \\
1,424.6 \\
1,424.2 \\
1,423.4 \\
1,422.6\end{array}$ & $\begin{array}{l}1,424.2 \\
1,423.2 \\
1,423.0 \\
1,421.8 \\
1,421.6\end{array}$ & $\begin{array}{l}1934- \\
1935- \\
1936- \\
1937 \\
1938\end{array}$ & $\begin{array}{l}1,408.3 \\
1,406.9 \\
1,406.7 \\
1,404.3 \\
1,403.4\end{array}$ & $\begin{array}{l}1,406.5 \\
1,406.1 \\
1,404.5 \\
1,403.2 \\
1,402.1\end{array}$ \\
\hline $\begin{array}{l}1910=- \\
1911^{-} \\
1912^{-} \\
1913 \\
1914 \ldots\end{array}$ & $\begin{array}{l}1,421.4 \\
1,420.4 \\
1,421.4 \\
1,421.8 \\
1,420.6\end{array}$ & $\begin{array}{l}1,420.2 \\
1,420.2 \\
1,420.4 \\
1,420.4 \\
1,419.6\end{array}$ & $\begin{array}{l}1939 \ldots \\
1940 \ldots \\
1941 \\
1942 \\
1943 \ldots\end{array}$ & $\begin{array}{l}1,402.7 \\
1,402.3 \\
1,402.8 \\
1,404.5 \\
1,404.7\end{array}$ & $\begin{array}{l}1,401.5 \\
1,400.9 \\
1,402.2 \\
1,404.0 \\
1,403.4\end{array}$ \\
\hline $\begin{array}{l}1915 \\
1916 \\
1917 \\
1918 \\
1919_{-}\end{array}$ & $\begin{array}{r}1,419.2 \\
1,419.6 \\
1,418.8 \\
1,417.4 \\
1,4\end{array}$ & $\begin{array}{l}1,418.4 \\
1,418.6 \\
1,417.2 \\
1,416.4 \\
0\end{array}$ & $\begin{array}{l}1944 \\
1945 \\
1946 \\
1947 \\
1948\end{array}$ & $\begin{array}{l}1,404.0 \\
1,404.7 \\
1,405.0 \\
1,403.6 \\
1,405.2\end{array}$ & $\begin{array}{l}1,403.0 \\
1,403.5 \\
1,403.3 \\
1,403.0 \\
1,404.2\end{array}$ \\
\hline $\begin{array}{l}1920 \ldots \\
1921 \ldots \\
1922 \ldots \\
1923 \ldots\end{array}$ & $\begin{array}{r}1,417.6 \\
1,416.7 \\
1,4 \\
1,4\end{array}$ & $\begin{array}{l}1,416.2 \\
1,416.6 \\
2 \\
3\end{array}$ & $\begin{array}{l}1949 \\
1950 \ldots \\
1951 \ldots \\
1952 \ldots\end{array}$ & $\begin{array}{l}1,407.2 \\
1,415.0 \\
1,415.5 \\
1,414.5\end{array}$ & $\begin{array}{l}1,405.6 \\
1,406.6 \\
1,414.3 \\
1,412.5\end{array}$ \\
\hline
\end{tabular}

1 A centered number is for a single observation during the year.

climatic change is a more logical reason for the general decline in the level of Devils Lake. However, before the possible effects of climatic change can be even approximately evaluated, some phases of the hydrology of the area must be considered.

\section{HYDROLOGY}

Statements in this section on hydrology are founded on incomplete basic information and on maps that are inadequate for much of the Devils Lake basin and should be considered as only approximations of the hydrologic processes.

Ground-water inflow and changes in ground-water storage have generally been disregarded, partly because ground-water movement is slow in much of Devils Lake basin and partly because information on ground-water movements at the shores of Devils Lake does not 


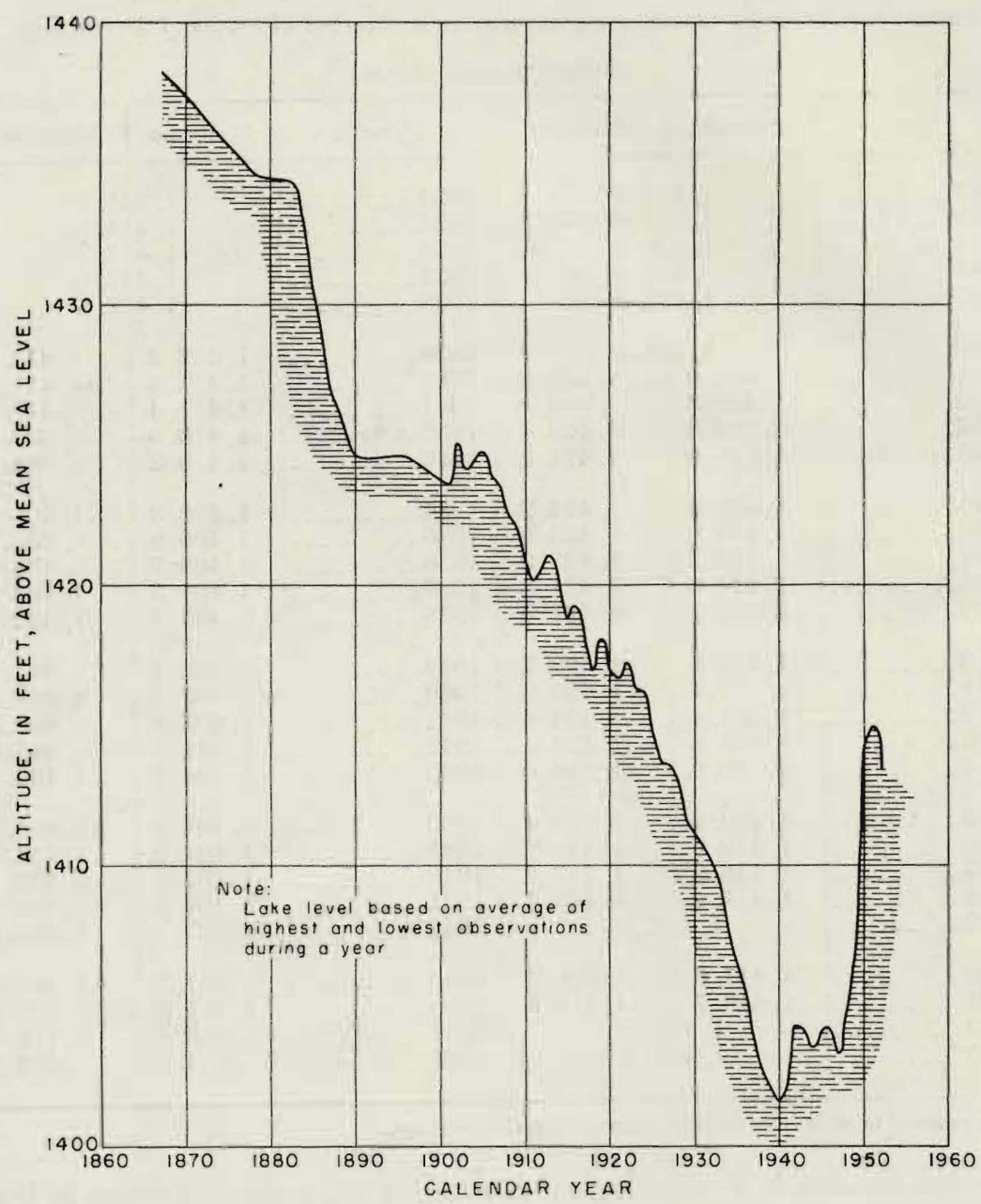

Figure 3.-Fluctuation in level of Devils Lake based on average of highest and lowest observations during year.

seem to be available. In the computation of inflow to Devils Lake by years, the assumption was made that changes in bank storage would amount to 5 percent of the changes in capacity of the lake.

Precipitation.-Precipitation at Devils Lake averages about 17.5 inches annually, but the precipitation since 1930 has been slightly below average. Figures 4 and 5 show annual precipitation and average monthly precipitation, respectively.

Evaporation.-Evaporation from a Class A Weather Bureau land pan at Devils Lake would be about 42 inches per year according to a map that has been prepared by R. E. Horton (1943). Evaporation 

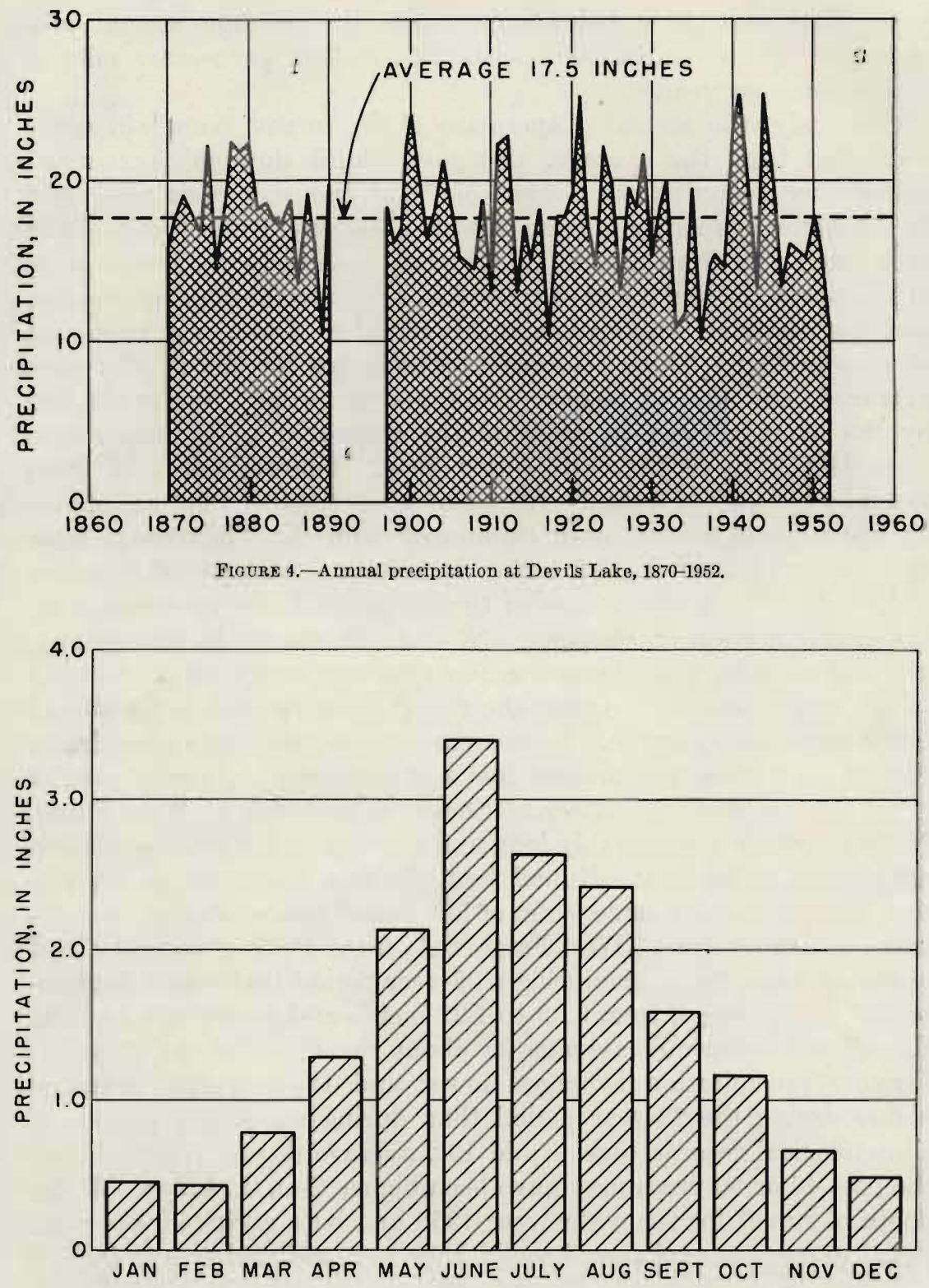

Figure 5.-Mean monthly precipitation at Devils Lake, 1870-1952.

from the surfaces of the relatively shallow lakes in the Devils Lake area probably averages at least 70 percent of the evaporation from a Class A pan. Thus, the average annual evaporation from a lake surface in the Devils Lake basin is estimated to be 30 inches per $326053-55-2$ 
year. The average evaporation exceeds the average annual precipitation by 12.5 inches or about 670 acre-feet per square mile of lake surface per year.

Obviously, the annual evaporation during many years will differ somewhat from the average. Seasonal (April through September) evaporation records from Bureau of Plant Industry pans were used to compute evaporation from Devils Lake by water years. For each water year from 1930 to 1952, inclusive, the seasonal evaporation at Dickinson, N. Dak., was expressed as a ratio to the 46 -year average, and the seasonal evaporation at Mandan, N. Dak., was expressed as a ratio to its 39-year average. The ratios for the 2 sites were averaged, and the 30 inches (average evaporation) was multiplied by the average ratio to compute the estimated gross evaporation from Devils Lake for each water year. The estimates of gross annual evaporation from Devils Lake from 1930 to 1952 are shown by water years in the ninth column of table 2 . They range from 22.8 inches in 1942 to 43.8 inches in 1936 and average 30.7 inches.

Runoff.-The drainage area of the Sheyenne River upstream from the gaging station at Sheyenne, N. Dak., is similar in topography, vegetation, soils, and climate to the drainage area that contributes runoff to Devils Lake, so that the runoff from the two areas should be somewhat comparable. Both areas contain many ponds and lakes. Runoff from these two areas is low and variable. Annual depths of runoff of the Sheyenne River at Sheyenne and also at West Fargo, N. Dak., where a reasonably long and continuous record is available, are plotted on figure 6 . Runoff from the area above the gaging station at Sheyenne for some years of low runoff was estimated by comparison with records at West Fargo. Average depth of annual runoff upstream from Sheyenne during a 22-year period that ended September 30,1951 , ranged from 0.02 to 1.22 inches and averaged 0.23 inch. Runoff was below this average for about two-thirds of the 22 years. Because precipitation averaged lower and temperatures averaged higher during the 22-year period than during the longer periods of climatological records (figs. 7 and 10), average annual runoff during the past 40 or 50 years may have been higher than 0.23 inch. If the depth of runoff for the water year 1950 had been excluded, the computed average annual runoff would have been reduced to $0.18 \mathrm{inch}$.

Runoff in the Sheyenne River basin, and presumably in the Devils Lake basin also, shows little relation to annual precipitation. (See fig. 7.) The runoff is derived almost entirely from snowmelt and spring rains. However, because of water storage in upstream lakes, the inflow to Devils Lake during wet years may continue throughout the summer through drainage from the Sweetwater chain of lakes. Precipitation in the basin during the summer and early fall produces 


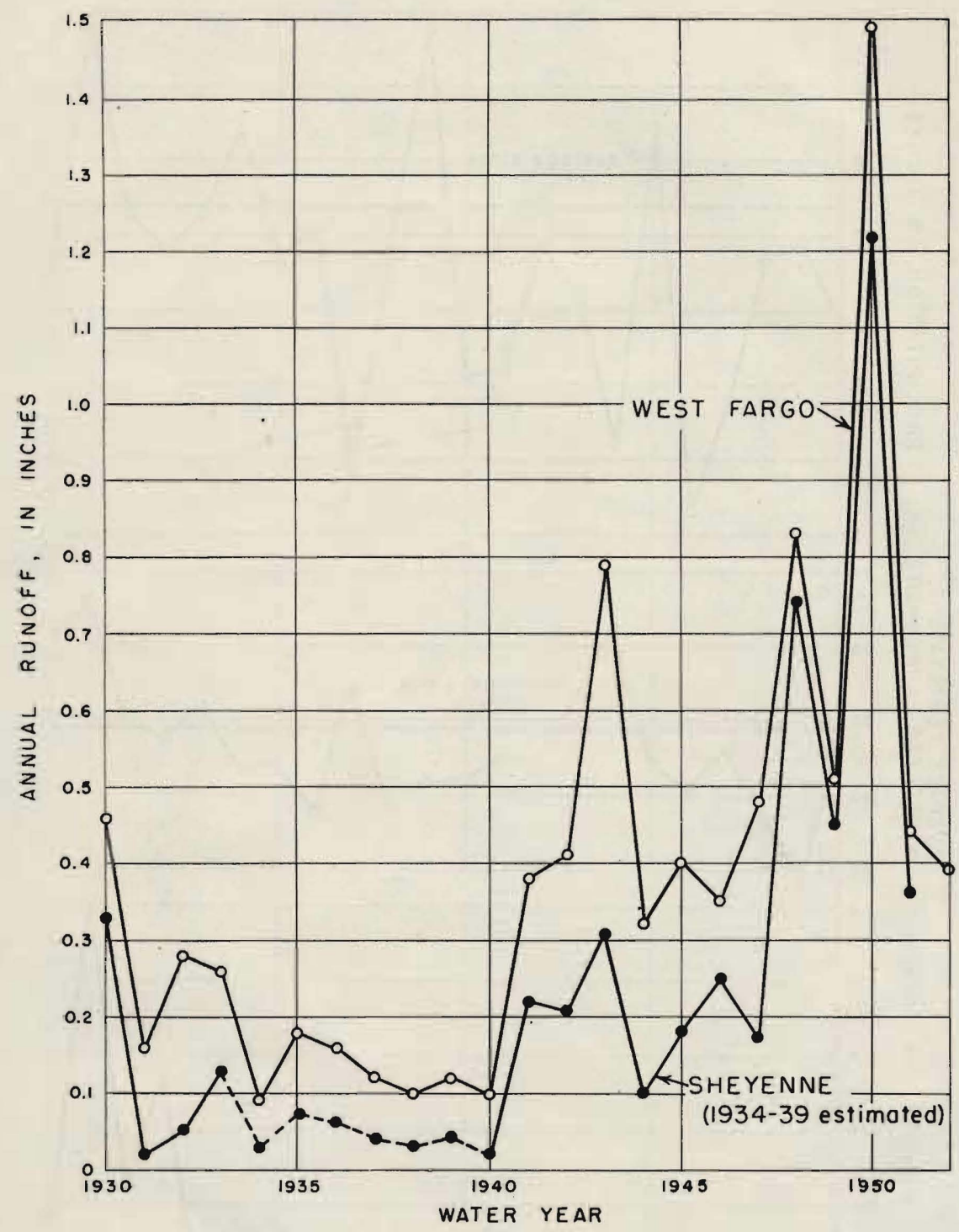

Figure 6. -Annual runoff of the Sheyenne River at Sheyenne and West Fargo.

little runoff, but precipitation on lake surfaces helps to maintain the lake levels. Farm practices may have no great effect on the runoff of the Sheyenne and Devils Lake basins because most of the runoff is generated either during the period when the ground is frozen or immediately after the ground thaws in the spring.

For a set amount of annual precipitation, runoff tends to be greater during years when temperatures are below normal. Such a relation- 


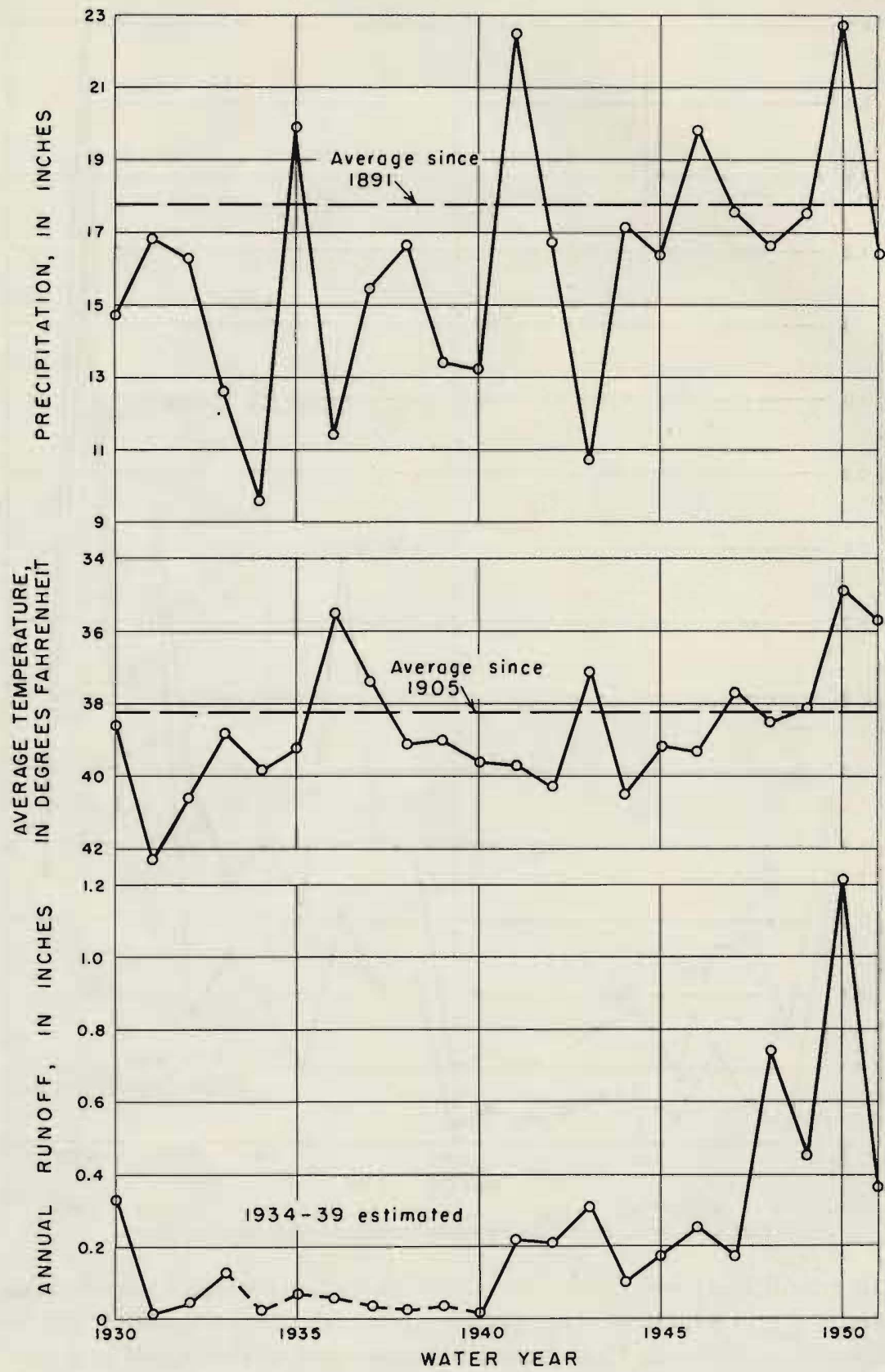

Figure 7.-Annual runoff of the Sheyenne River above Sheyenne compared with temperature at Devils: Lake and annual precipitation at Maddock. 
ship is logical. During a year when the temperature for each month averaged $1^{\circ} \mathrm{F}$ above normal for the Devils Lake area, the evaporation from water surfaces might be 0.5 to 1.0 inch greater than during a year of normal temperature. The evaporation from land surfaces computed from a graph by Meyer (1928) would be about 0.07 inch greater than for a year of normal temperature.

No estimate is here made of the increase of transpiration with increased temperature, but in years when sufficient soil moisture is available, transpiration will be significantly increased by temperatures that average a degree higher than normal. An increase of only 1 degree in mean arnual temperature may increase water losses by as much as 0.05 to 0.10 inch over the total drainage area and thus decrease the runoff from the basin by an equivalent amount.

The graphs of figure 8 show the relations between annual precipitation and annual runoff and between annual temperature and annual runoff for the Sheyenne River at Sheyenne, N. Dak., based on 22 years of record. A multiple linear correlation of the same variables gave the following equation: $R=2.95+0.038 P-0.086 T$, in which $R$ is runoff, in inches, during the water year; $P$, precipitation during the water year; $T$, temperature, in degrees Fahrenheit. The standard error of estimate of this correlation is 0.195 inch, and the coefficient of correlation is 0.71 .

The variation of runoff with temperature is consistent with that found by W. B. Langbein, U. S. Geological Survey (unpublished report), for the Red River at Grand Forks, N. Dak. He found by multiple linear correlation that the annual runoff varied inversely by as much as 0.10 inch per degree of temperature change.

Although the available records are short and the relationships are affected predominately by the cold, wet year of 1950 , the data indicate that a 1-degree rise in average annual temperature may be associated with a decrease of 0.08 or 0.09 inch of runoff per year, whereas a 1-inch decrease in annual precipitation may be associated with a decrease of about 0.03 or 0.04 inch of runoff per year. These relationships, even though poorly defined and perhaps distorted by the data for 1950, emphasize the possible effect of annual average temperatures on runoff. The higher than normal temperatures since 1930, particularly from 1930 to 1940 , probably considerably decreased the inflow to Devils Lake as well as increased the evaporation from it.

Inflow to lakes.-Flow into lakes in the Devils Lake basin is characterized by infrequent, large inflows from spring runoff and by long periods of low, intermittent inflow. For Devils Lake this characteristic distribution of inflow is magnified because a larger percentage of runoff is stored in upstream lakes during years of low runoff than during years of high runoff. 

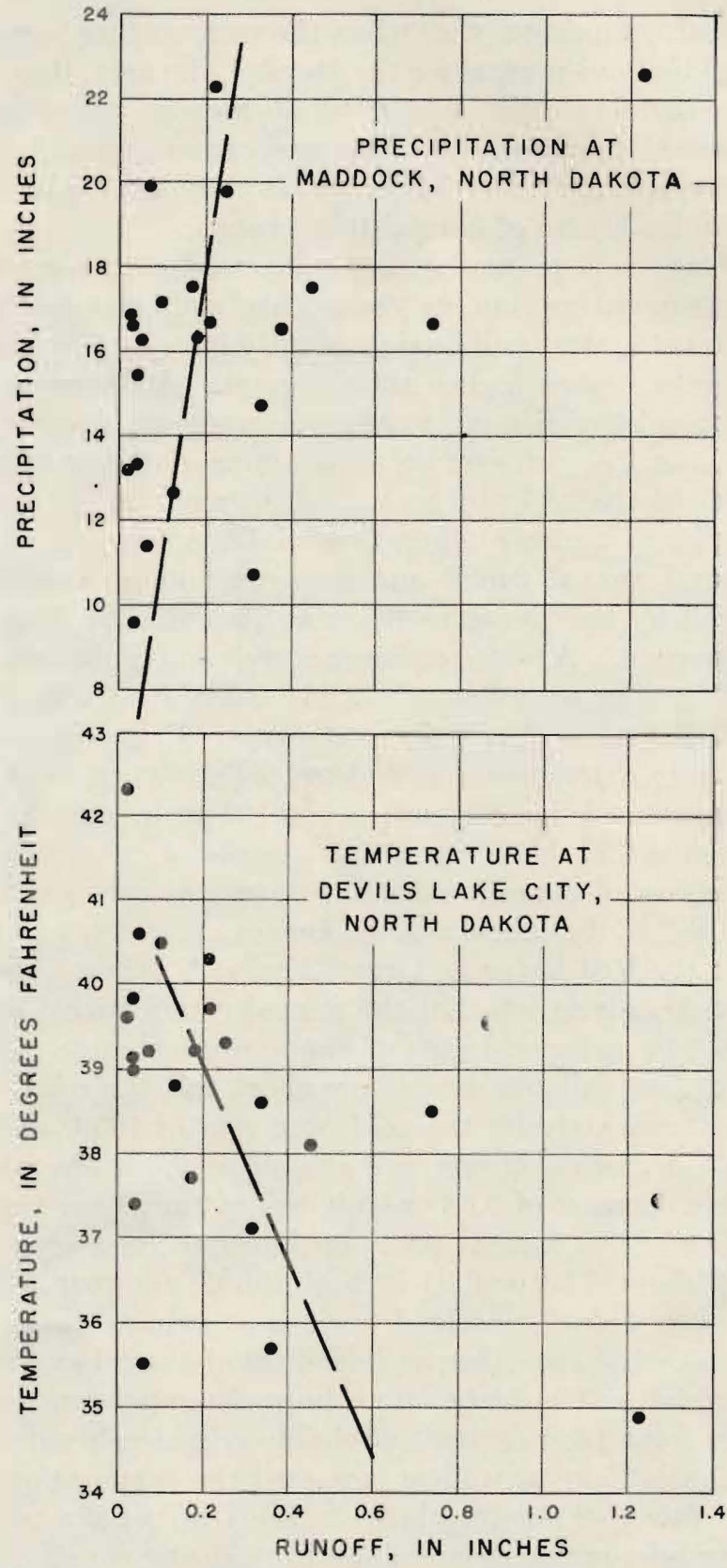

Ficure 8.-Runoff, for water years 1930-52, of Sheyenne River upstream from Sheyenne versus annual precipitation and annual average temperature. 
Measurements of the flow of Mauvais Coulee before May 1949 are not available. Since then, occasional measurements have been made during periods of flow. Most of the measurements were made below the mouth of Little Coulee and at the southeast corner of sec. 2, T. $154 \mathrm{~N}$., R. $67 \mathrm{~W}$., where the total drainage area is about 2,600 square miles. Measurements at this site are in the following tabulation:

Streamflow measurements of Mauvais Coulee, 6 miles south of Churchs Ferry,
May 1949 to December 1952

1949:

Date

Discharge in cubic feet

May $9 \ldots$

Aug. 22

1950:

May $3 \ldots \ldots 7$

May 24_... 514

June 7 _

June $9 \ldots \ldots \ldots$

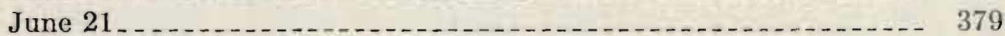

July $7 \ldots \ldots \ldots$

Aug. 2 . . .

Sept. 1_._.

Sept. $16 \ldots \ldots \ldots$

Sept. 18_........... 32.7

Oet. 14

Nov. 18 . 8

Dec. 9 .

1951:

Apr. 5

Apr. $10 \ldots \ldots \ldots$

Apr. 13... 18.1

Apr. 16

May 1...

May $16 \ldots \ldots$. 60.7

June $26 \ldots \ldots \ldots$. 10

July $19 \ldots \ldots$

1952:

Apr. 11... 2

1385 efs measured on May 10 about 10 miles downstream.

Mauvais Coulee receives little inflow between the point where these measurements were made and Devils Lake; however, at times, surface inflow from an area of 300 or 400 square miles enters the lake through other small channels.

Though no continuous records are available of runoff within the closed basin of Devils and Stump Lakes, yet the net inflow to the main part of Devils Lake during some years can be approximated by adjusting the change in volume of water in the lake by the amount of precipitation on the lake surface and by the estimated evaporation. 
Computed annual volumes of inflow to Devils Lake from 1930 to 1952 are shown in table 2. They average 12,800 acre-feet. (A rounded volume of 12,000 acre-feet is used in computations later in this report.)

The computations in table 2 are mostly self-explanatory. Volumes of water for given altitudes were taken from a table that was prepared as a basis for the capacity curve of figure 9. The computed changes in contents in the lake were increased by 5 percent as an arbitrary adjustment for the change in ground-water storage that was associated with changes in lake level. Precipitation figures were taken from Weather Bureau records near the city of Devils Lake. Annual evaporation was estimated as explained on page 10. Obviously, the figures of computed inflow to Devils Lake are subject to relatively large errors because of the uncertainty of the basic information. For example, the small negative-figure for estimated inflow to the lake during 1944 is likely due to an excessively high figure for precipitation during the water year. Presumably the precipitation at the city of Devils Lake may not have been representative of the average precipitation on the entire lake surface during the water year. The water-year precipitation at Maddock, 27 miles southwest of the lake, was only 17.08 inches as compared to 23.53 inches 7 miles northeast at the city of Devils Lake.

The computed annual inflows to Devils Lake are plotted on figure 10 together with annual precipitation, average annual temperature, and seasonal evaporation from Bureau of Plant Industry pans. These inflows show only a slight relation to annual precipitation and to average annual temperature. Some general relation does seem to exist between evaporation from the Bureau of Plant Industry evaporation pans and inflow to Devils Lake.

The computed volumes of inflow are expressed in inches of depth on drainage areas of 800 square miles and 3,000 square miles in the last 2 columns of table 2. The reason for the implied wide range in effective area tributary to Devils Lake is as follows: Devils Lake is only one lake of a chain, which begins with the Sweetwater group of lakes and extends successively through Devils Lake, East Bay Devils Lake, and East Devils Lake, to Stump Lake. Figure 11 is a schematic sketch of the chain of lakes and their drainage areas. The numbers in the lake areas on this figure are water surface altitudes about the middle of May 1952. Underlined numbers between two lakes show the altitude that the upstream lake must reach before overflowing into the next lake. At present (1953) and probably since about 1922 when State Route 20 was constructed across the "narrows," Devils Lake has been separated from East Bay 


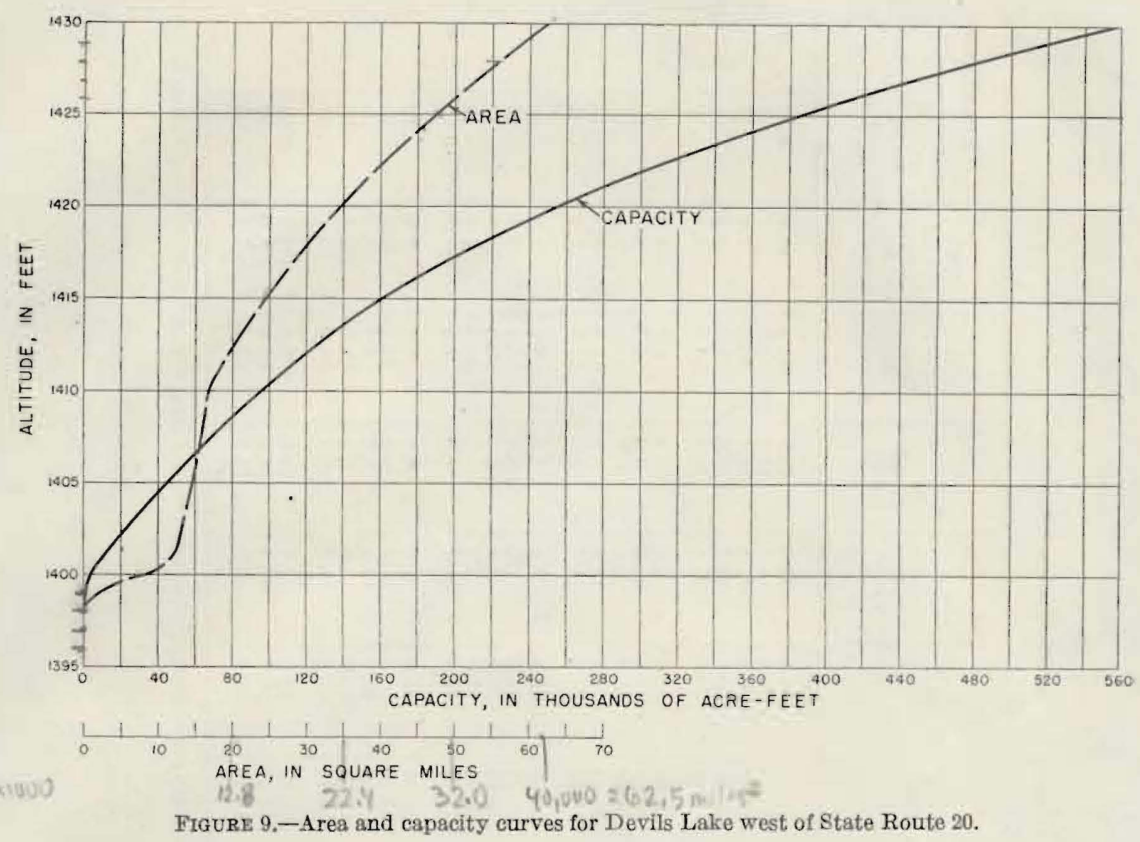

Devils Lake. Hence, the term "Devils Lake" may conveniently be restricted to the area west of State Route 20.

The total drainage area that is tributary to Devils Lake at the present time is, then, about 3,000 square miles. Only about 400 square miles of this drainage area is downstream from lakes of significant size (fig. 11), such as Lake Irvine and Ibsen Lake, and even these 400 square miles contain many "potholes" and have few defined drainage channels. About 400 square miles of additional area contributes surface runoff to Devils Lake only when Ibsen Lake overflows. Ibsen Lake has a surface area of only 1 or 2 square miles, so it probably overflows during most years. Hence, during many or even most years, Devils Lake receives surface runoff from not more than these 400 or 800 square miles of drainage area, which has few defined stream channels. In contrast, during wet years, runoff may be received from about 3,000 square miles of area, which has some developed stream channels. The additional 2,200 square miles of drainage area is upstream from Lake Irvine and Lac Aux Mortes; about 1,000 square miles of this is also upstream from Sweetwater and Dry Lakes. These four large upstream lakes overflow only during years of relatively high runoff. The large differences in area of effective drainage, plus the wide range of runoff per square mile (fig. 6), explain the wide variation in surface inflow to Devils Lake from year to year. 


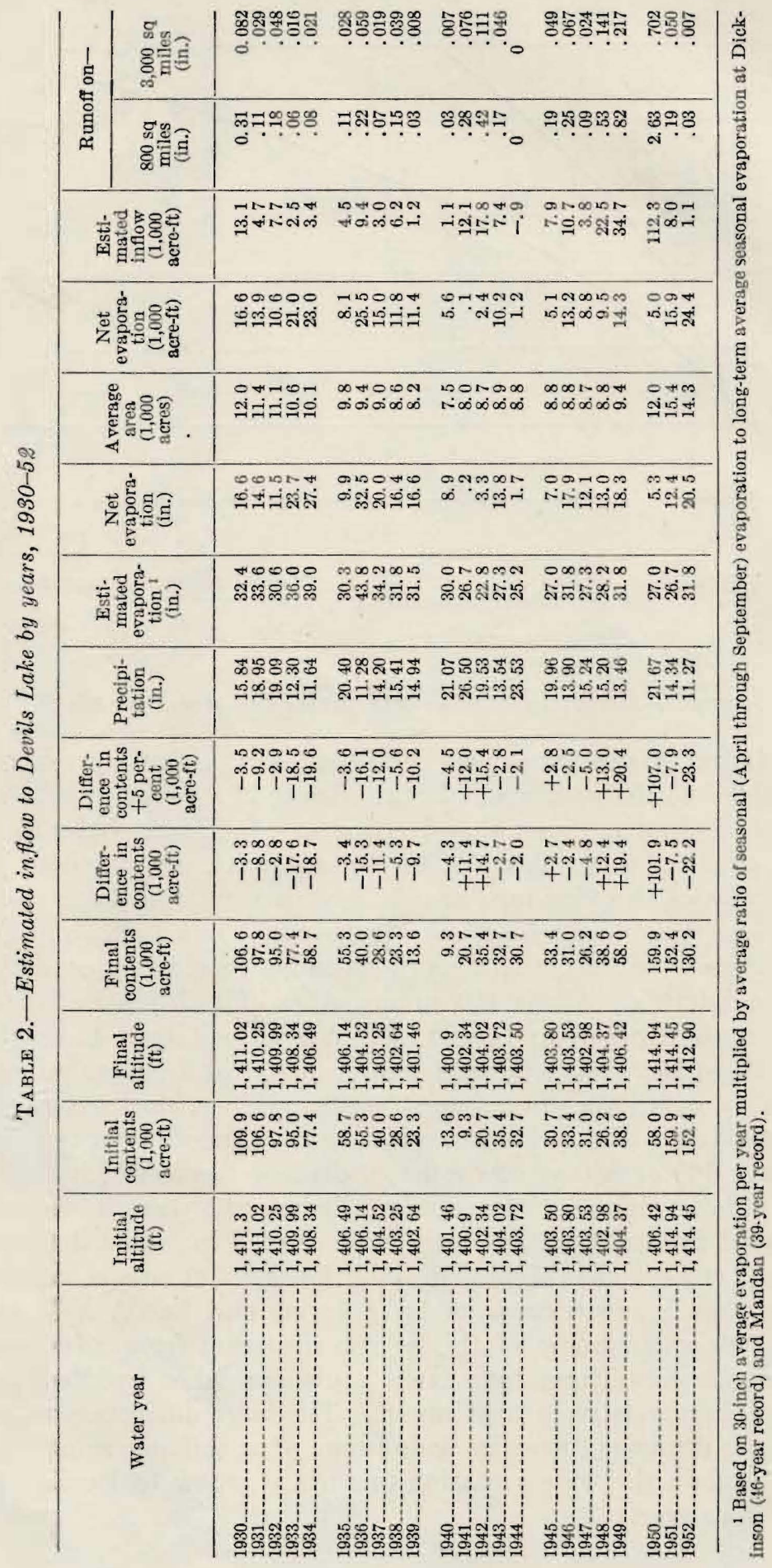




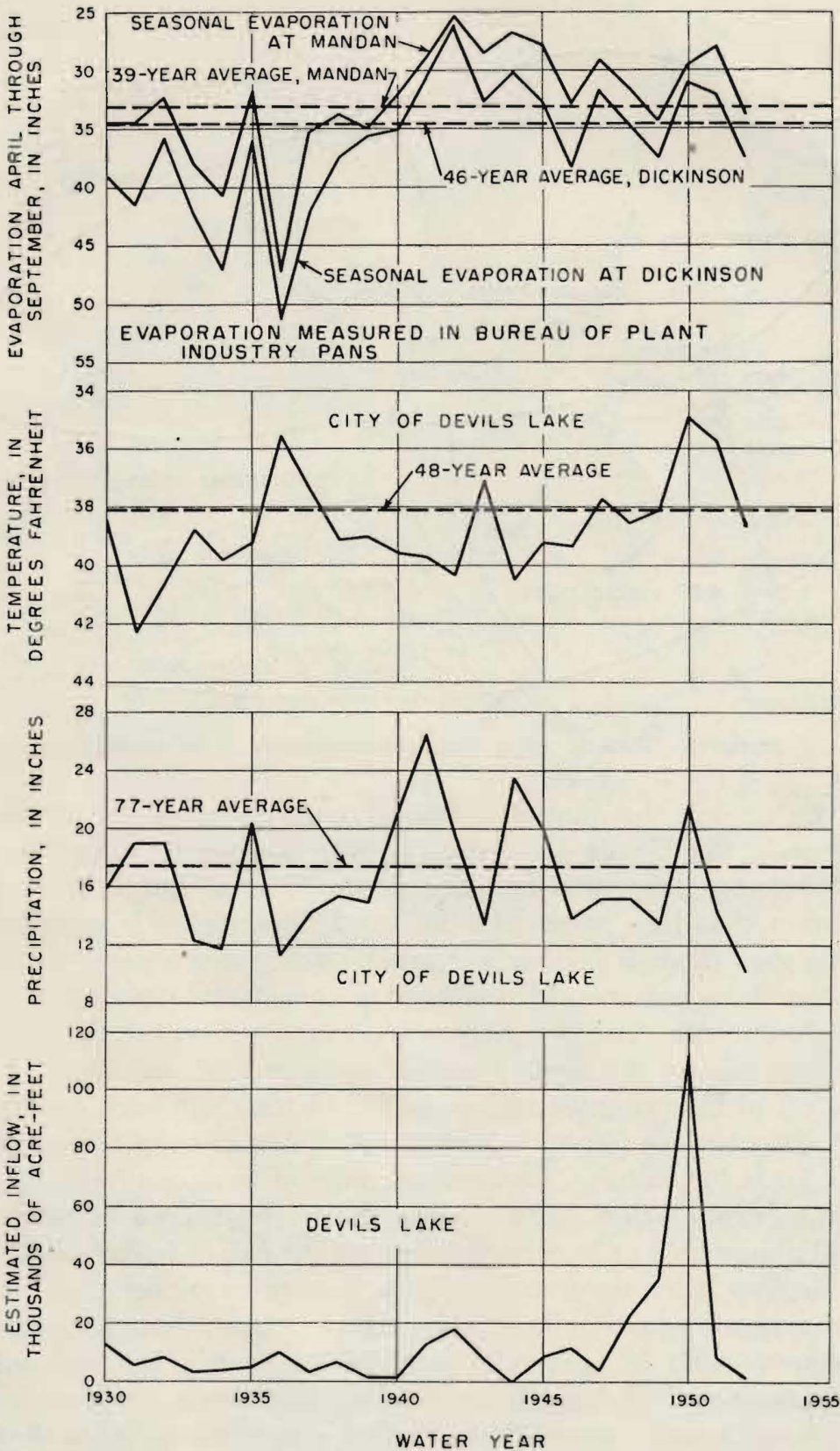

Figure 10.-Computed annual inflow to Devils Lake and significant climatological factors. 


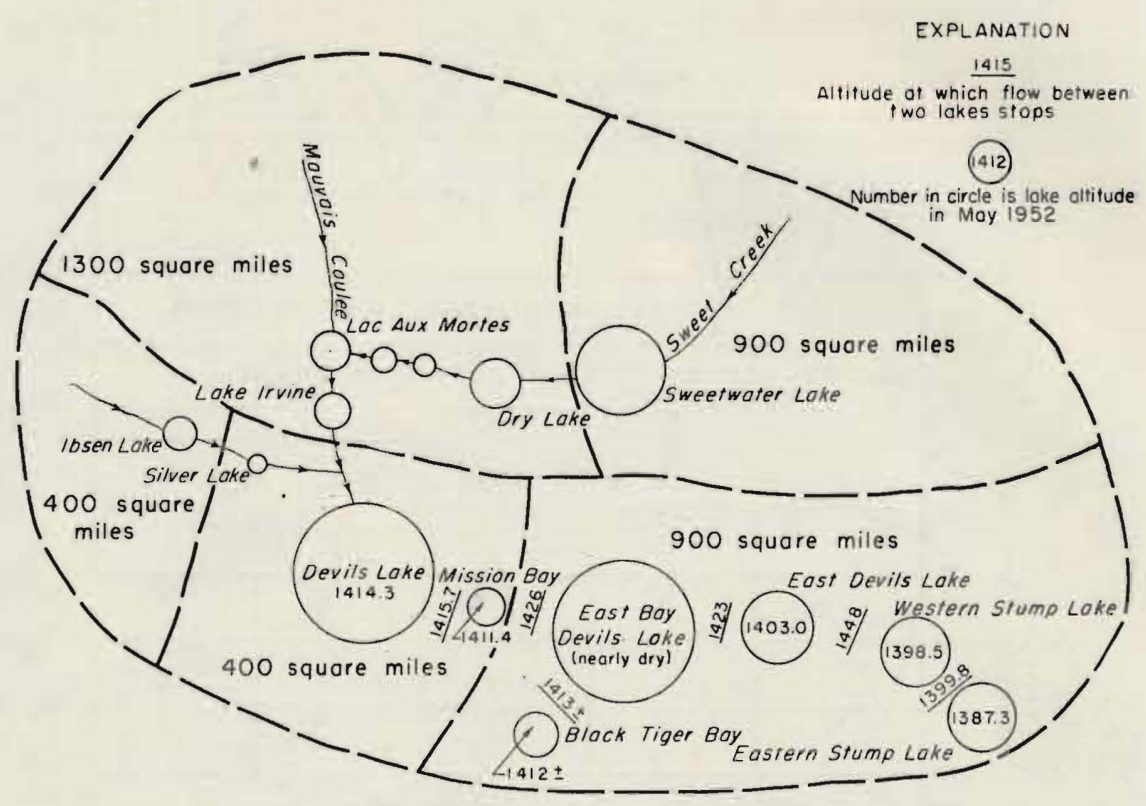

FIGURE 11.-Schematic map of lakes and drainage areas in the Devils Lake basin.

Even though the annual depth of runoff varies widely from year to year in the Devils Lake region, some average relationship must exist between lake area and the drainage area that is required to maintain that lake area. As the word "maintain" is used here, it means that there is neither a generally rising nor a generally falling trend of lake surface altitude over a considerable period of years. If the annual runoff is assumed to average $0.23 \mathrm{inch}$ (p. 12), the yield from a square mile of drainage area will average 12.3 acre-feet. As 670 acre-feet of inflowing water is required to maintain each square mile of the lake surface (see p. 12), about 55 square miles of tributary area is required to maintain each square mile of surface of Devils Lake. Because evaporation from shallow lakes, whose water warms up rapidly, may be 2 or 3 inches greater per year than from Devils Lake, the shallow lakes may require 65 square miles of drainage area to maintain each square mile of lake surface. Even though a particular lake area could be generally maintained over a long period, the fluctuations in lake level from year to year would be large because the annual runoff varies widely. Also, considerably more than half the years can be expected to have less than average runoff. The expected behavior of surface level in a lake that is being maintained would be for the lake to decline during most years and to rise, perhaps sharply, during a few years. 
If an average of about 60 square miles of drainage area is required to maintain 1 square mile of lake surface, the 3,940 square miles of the entire closed basin of Devils and Stump Lakes can maintain only 60 to 70 square miles of lake surface. In May 1952 the surface area of Devils Lake, Black Tiger Bay, East Devils Lake, and Stump Lake totaled about 39 square miles. Except for Black Tiger Bay, the East Bay of Devils Lake was almost completely dry. (Pl. 1 is based on 1950 water levels when East Bay of Devils Lake was higher.) Although adequate maps are not available for most of the small lakes upstream from Devils Lake, the total water surface of these small lakes may have been 35 square miles or more in May 1952 and probably exceeded 45 square miles during the summer of 1950 . The total lake surface in May of 1952 was probably about 75 square miles. This is a larger area than is likely to be maintained by an average of 0.23 inch runoff per year.

During 1940 the total lake surface of Devils Lake, East Devils Lake, and Stump Lake was probably less than 20 square miles and was decreasing. The area of the upstream lake surfaces was small but unknown. From 1931 to 1940, an extended dry period, annual averages of runoff and of net evaporation were about 0.05 inch and 18 inches, respectively. This net evaporation is about 5.5 inches greater than the assumed longtime average. During this dry period the total lake surface that could be maintained in the Devils and Stump Lakes basin was probably only about 10 square miles.

One obvious way of maintaining Devils Lake at a higher level would be to drain the upstream lakes by deepening their outlets. If upstream lakes were eliminated, the 3,000 square miles of effective drainage area might then maintain Devils Lake (west of State Route 20) somewhere near an altitude of 1,425 feet during periods of average runoff. However, elimination of these upstream lakes may be neither feasible nor desirable. If these lakes were drained, existing wildlife resources would be damaged.

From October 1930 to October 1940 the surface of Devils Lake fell about 10 feet. During this 10-year period the precipitation averaged 15.9 inches, the temperature averaged 39.1 degrees, and the estimated evaporation from the lake averaged 34.1 inches. During the 10-year period that ended October 1, 1950, the lake rose 14 feet. The precipitation averaged 18.2 inches, the temperature averaged 38.5 degrees, and the estimated evaporation averaged 27.5 inches. During this second 10-year period, the precipitation and temperature were each slightly above their longtime averages, and the estimated evaporation was about 8 percent lower than average. Although climatological averages are not too significant in relation to runoff and lake altitudes, nevertheless the 14 -foot rise in lake level during 10 
years when the temperature, precipitation, and evaporation were not far from average is noteworthy. This rise in lake level is not likely to have been caused by changes in agricultural practices but probably was due to small changes in the weather. Similarly, small changes in weather in the future may determine the size of Devils Lake and the other lakes in the Devils Lake basin unless water is diverted to them from a source outside the basin.

\section{CHEMICAL AND PHYSICAL PROPERTIES OF THE LAKE WATERS}

In the closed Devils Lake basin the runoff collects in depressions where continued evaporation forms saline or alkaline lakes. In extremely dry years, when evaporation is rapid, these lakes may become beds of saline residues or may exist for some time in a semisolid state. During a wet cycle, on the other hand, when runoff from melting snow and from precipitation is above normal, the lakes receive fresh water, which dilutes the concentration of dissolved solids. The salinity of water in Devils Lake fluctuates in this manner. In November 1948 the concentration of dissolved solids was 25,000 parts per million (ppm). This concentration had decreased to 17,300 ppm in May 1949 as a result of inflow of fresh water, principally from Mauvais Coulee. In May 1950 when Mauvais Coulee was discharging a considerable volume of water into Devils Lake, the concentration of dissolved solids was reduced further to about $7,000 \mathrm{ppm}$. In this 19-month period from November 1948 to May 1950 the lake stage had risen 7 feet, and the concentration of salts had diminished over 70 percent. Thus, the salinity of waters in a closed basin is not constant but varies with climatic changes and hydrologic features peculiar to the area.

\section{PRELIMINARY CONSIDERATIONS}

Natural water free of colloidal material is essentially a solution of mixed salts and gases. When concentrated by evaporation, this solution undergoes chemical change in accordance with the solubilities of those salts present in the water. The least soluble salts will precipitate first, and the most soluble will remain in solution the longest. If a water containing the chlorides, sulfates, and carbonates (as bicarbonates) of sodium, calcium, and magnesium is evaporated, the sparingly soluble carbonates of calcium and magnesium will be precipitated first and the moderately soluble calcium sulfate second. Sodium sulfate and sodium carbonate will precipitate next, followed by sodium chloride and magnesium sulfate, and the very soluble chlorides of calcium and magnesium will remain in solution. 
This order of precipitation is simply the general order that conforms to the known solubilities of the several salts, and every step in this general order is not necessarily taken. For example, all the calcium may be eliminated as carbonate, and none would be left for the formation of other salts; all the sulfate may be combined with calcium, and sodium sulfate would then be absent. Actually, the chemical changes occurring during the concentration of a specified water depend on its composition and differ from one water to another. If calcium is deficient, for instance, evaporation produces residual mixed waters in which alkaline sulfates, carbonates, and chlorides may coexist in all possible proportions. Natural water is a complex solution of many salts; as Clarke (1924) has pointed out, the solubility of a salt in pure or distilled water is entirely different than solubility in the presence of other compounds. Furthermore, when the number of possible compounds is large, the issue becomes even more complicated because each salt influences every other salt to a degree that is determined by temperature and concentration.

Changes in concentration resulting from evaporation of natural water are illustrated by the following experiment: Two liters of water similar in composition to the inflow from Mauvais Coulee was evaporated by boiling to about one-tenth of the original volume. Analyses of this water before and after evaporation are shown in the following table:

Analyses of water sample before and after evaporation to about one-tenth original volume

\begin{tabular}{|c|c|c|}
\hline Constituent & $\begin{array}{l}\text { Before evapo- } \\
\text { ration }\end{array}$ & $\begin{array}{l}\text { After evapo- } \\
\text { ration }\end{array}$ \\
\hline 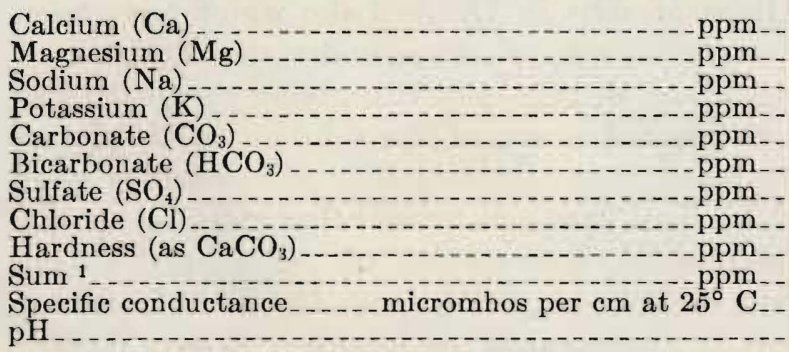 & \begin{tabular}{r|}
59 \\
11 \\
31 \\
7.7 \\
0 \\
213 \\
77 \\
13 \\
194 \\
304 \\
516 \\
7.7
\end{tabular} & $\begin{array}{r}60 \\
58 \\
328 \\
74 \\
17 \\
199 \\
770 \\
135 \\
386 \\
1,540 \\
2,230 \\
8.5\end{array}$ \\
\hline
\end{tabular}

1 Sum based on conversion of $\mathrm{HCO}_{3}$ to $\mathrm{CO}_{3}$ by dividing by 2.03 .

A decrease in total mineral content results from partial precipitation of calcium and magnesium carbonates; this loss at $100^{\circ} \mathrm{C}$, the boiling point of water, is actually greater than would result from solar evaporation. The following data are of interest, however, in showing, semiquantitatively, losses in mineral content through chemical precipitation of certain salts. 
Loss of mineral content in water sample by chemical reaction

\begin{tabular}{l|r|r|r}
\hline \multicolumn{1}{c|}{ Constituent } & $\begin{array}{r}\text { Original } \\
\text { weight } \\
(\mathrm{mg})\end{array}$ & $\begin{array}{r}\text { Final weight } \\
(\mathrm{mg})\end{array}$ & $\begin{array}{r}\text { Net loss } \\
(\mathrm{mg})\end{array}$ \\
\hline Calcium $(\mathrm{Ca})$ & 118 & 12 & 106 \\
Magnesium $(\mathrm{Mg})$ & 22 & 12 & 10 \\
Carbonate $\left(\mathrm{CO}_{3}\right)$ & 210 & 23 & 187 \\
\hline
\end{tabular}

*Ineludes equivalent of bicarbonate.

The change in chemical character is readily apparent, as shown in the following table:

\begin{tabular}{|c|c|c|}
\hline Constituent & $\begin{array}{c}\text { Before } \\
\text { evaporation }\end{array}$ & $\begin{array}{c}\text { After } \\
\text { evaporation }\end{array}$ \\
\hline $\begin{array}{l}\text { Calcium }(\mathrm{Ca}) \\
\text { Magnesium }(\mathrm{Mg}) \\
\text { Sodium }(\mathrm{Na}) \\
\text { Potassium }(\mathrm{K}) \\
\text { Carbonate }\left(\mathrm{CO}_{3}\right)^{2} \\
\text { Sulfate }\left(\mathrm{SO}_{4}\right) \\
\text { Chloride }(\mathrm{Cl})\end{array}$ & $\begin{array}{r}\text { 19. } 4 \\
\text { 3. } 6 \\
10.3 \\
2.6 \\
\text { 34. } 6 \\
25.3 \\
4.3\end{array}$ & $\begin{aligned} \text { 3. } 9 \\
3.8 \\
21.3 \\
4.8 \\
7.5 \\
50.0 \\
8.7\end{aligned}$ \\
\hline Salinity & $\begin{array}{l}100.0 \\
304\end{array}$ & 1,540 \\
\hline
\end{tabular}

The concentration of salts in natural water by evaporation produces marked changes in the relationship of the individual constituents originally present. Calcium and carbonate in the above example are now less significant, whereas sodium and sulfate are the principal ions.

The solubility relations of salts in Devils Lake water have been investigated by Nerhus, ${ }^{1}$ who was working under the direction of Professor G. A. Abbott (1924, p. 182-183). Applying the phase rule principle, they made a detailed study of the solubilities of salts in Devils Lake and concluded that the solubility relationships were much simpler in the lake than in sea water or other chloride waters. By solar evaporation and fractional crystallization, Nerhus and Abbott succeeded in separating the following salts from Devils Lake water: mirabilite $\left(\mathrm{Na}_{2} \mathrm{SO}_{4} \cdot 10 \mathrm{H}_{2} \mathrm{O}\right)$; astrakanite or blodite $\left(\mathrm{Na}_{2} \mathrm{SO}_{4} \cdot \mathrm{MgSO}_{4}\right.$. $\left.4 \mathrm{H}_{2} \mathrm{O}\right)$; halite $(\mathrm{NaCl})$; and sylvite $(\mathrm{KCl})$.

Some understanding of concentrations of salts in the major lakes and waterways is necessary to understand the quality-of-water problems relevant to restoration of the Devils Lake chain. In the following table, maximum and minimum observed concentrations of dissolved solids are reported for the period 1948-52.

\footnotetext{
1 Nerhus, P. T., 1920, A study of solubility relations of the salts in Devils Lake water: Thesis for Master of Sci. Degree, N. Dak. Univ., 41 p.
} 
Ranges in concentration of dissolved solids in samples from principal lakes and waterways, $1948-52$

\begin{tabular}{|c|c|c|c|c|c|}
\hline \multirow[b]{2}{*}{ Source } & \multicolumn{5}{|c|}{ Samples } \\
\hline & $\begin{array}{l}\text { Maximum } \\
\text { concentration } \\
\text { (ppm) }\end{array}$ & Date sampled & $\begin{array}{c}\text { Minimum } \\
\text { concentration } \\
(\mathrm{ppm})\end{array}$ & Date & sampled \\
\hline Mauvais Coulee & 696 & Nov. 18,1950 & 276 & May & 24,1950 \\
\hline Devils Lake_ & 25,000 & Nov. 20,1948 & 6,130 & May & 3,1950 \\
\hline Mission Bay & 59,300 & Mar. 28,1952 & 9,340 & June & 20,1949 \\
\hline East Devils Lake. & 62,000 & Mar. 28,1952 & 35,300 & Aug. & 1,1950 \\
\hline Stump Lake: & & & & & \\
\hline $\begin{array}{l}\text { Western arm } \\
\text { Eastern arm }\end{array}$ & $\begin{array}{r}15,000 \\
106,000\end{array}$ & $\begin{array}{l}\text { Mar. } 29,1952 \\
\text { Mar. } 29,1952\end{array}$ & $\begin{array}{r}2,410 \\
43,900\end{array}$ & $\begin{array}{l}\text { June } \\
\text { June }\end{array}$ & $\begin{array}{l}14,1950 \\
14,1950\end{array}$ \\
\hline
\end{tabular}

Rankama and Sahama (1950) reported the average composition of dissolved solids in lake, river, and sea waters. For comparison, the following table gives these average results and the percentages of principal constituents for waters from Mauvais Coulee, Devils Lake, and eastern Stump Lake.

Average percentage composition of dissolved solids in several waters

\begin{tabular}{|c|c|c|c|c|c|}
\hline Constituent & $\begin{array}{l}\text { Lake and } \\
\text { river } \\
\text { waters }\end{array}$ & Sea water & $\begin{array}{c}\text { Mauvais } \\
\text { Coulee }\end{array}$ & $\begin{array}{l}\text { Devils } \\
\text { Lake }\end{array}$ & $\begin{array}{l}\text { Eastern } \\
\text { Stump } \\
\text { Lake }\end{array}$ \\
\hline Calcium (Ca) & 20. 39 & 1. 15 & 18. 6 & 0.6 & 0.1 \\
\hline Magnesium (Mg) _ - & 3. 41 & 3. 69 & 6. 2 & 4. 8 & 6. 5 \\
\hline Sodium (Na) & 5. 79 & 30.62 & 10. 1 & 24. 4 & 21. 8 \\
\hline Carbonate $\left(\mathrm{CO}_{3}\right) * \ldots$ & 35. 15 & $4 \overline{1}$ & 41. 2 & 4. 6 & \\
\hline Sulfate $\left(\mathrm{SO}_{4}\right) \ldots$ & 12. 14 & 7. 68 & 21. 2 & 51. 6 & 57. 8 \\
\hline Chloride (Cl) ... & 5. 68 & 55.04 & 2. 7 & 11. 5 & 11. 7 \\
\hline
\end{tabular}

"Includes equivalent of bicarbonate.

\section{SWEETWATER GROUP OF LAKES}

The Sweetwater group constitutes an extensive chain of lakes, which include Sweetwater Lake, Dry Lake, Lac Aux Mortes, and Lake Irvine. In former years these lakes were connected by a series of small coulees that at times discharged considerable volumes of water into Mauvais Coulee. The general decline in lake levels in the area ended the flow between these lakes, and the Sweetwater group became disconnected bodies of water whose depth fluctuates with climatological changes. Most of these lakes are shallow; and some, particularly Dry Lake, are marshes that are occasionally dry. Sweetwater Lake, the largest of this group, lying a few miles north of the city of Devils Lake, was nearly dry during the drought years of the 1930's but overflowed in 1951. Sweetwater Inlet, to which Sweet Creek is a tributary, enters this lake at its eastern boundary.

$$
\text { 326053-55-3 }
$$


The Sweetwater group of lakes is the first link in the Devils Lake system (fig. 11). Unlike Devils Lake and other major lakes lying in the lower end of the closed basin, the Sweetwater group, as suggested by their name, consists of fresh-water lakes. Samples taken from four lakes and Sweet Creek in June 1949 showed that these waters are hard but only moderately mineralized and of calcium bicarbonate type. Extremes in concentration of dissolved solids at that time are represented by Dry Lake (232 ppm) and Sweetwater Lake $(450 \mathrm{ppm})$. The latter is the present local source of water for industrial use by the Otter Tail Power Co. and the Great Northern Railroad. Water in the Sweetwater group of lakes is slightly alkaline; the $\mathrm{pH}$ ranged from 7.3 to 7.5 . Complete analyses are reported in table 3 , and sampling data are given in table 4 .

\section{MAUVAIS COULEE}

Mauvais Coulee is the largest drainage channel in the Devils Lake system and the principal tributary to Devils Lake. This coulee flows intermittently, largely in response to snowmelt and excessive precipitation during the spring. For extended periods Mauvais Coulee has been a dry creekbed, and even spring thaws have not induced flow in a number of years. However, about 1883 during the settlement of the region, Mauvais Coulee had substantial flows, as evidenced by the maintenance of a wagon ferry at Churches Ferry, a short distance below the outlet of Lake Irvine. Both in 1949 and 1950 , the coulee carried appreciable flows. (See p. 17.) Except for occasional flows during a wet climatic cycle, the recorded history of Mauvais Coulee has mostly been that of a drywash, which partly explains the gradual 60-year decline in level of Devils Lake.

Thirteen analyses of water taken from Mauvais Coulee in the period from June 1949 to May 1951 revealed properties are similar to those of waters in the Sweetwater group of lakes. This is understandable because Mauvais Coulee, in its southerly course to Devils Lake, enters the western end of the Sweetwater group, loses its identity in the lake waters, and finally reappears at the outlet of Lake Irvine. The coulee water in the vicinity of Churchs Ferry is hard and moderately mineralized. Concentration of dissolved solids averaged $363 \mathrm{ppm}$, and hardness ranged from 174 to $438 \mathrm{ppm}$. Analytical results appear in table 5.

\section{SILVER LAKE}

Below Churchs Ferry, Mauvais Coulee receives some inflow from a small coulee that drains Silver Lake and in turn Ibsen Lake (not sampled) to the northwest. Silver Lake is a fresh-water lake; an analysis of the water in this lake (table 3 ) shows the same chemical character as Maurais Coulee water. 


\begin{tabular}{|c|c|c|c|c|c|c|}
\hline & & 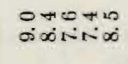 & 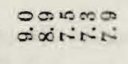 & 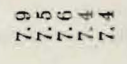 & 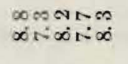 & 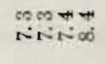 \\
\hline & 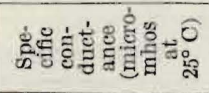 & 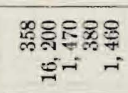 & 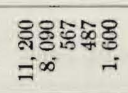 & 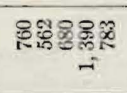 & 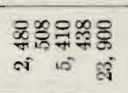 & 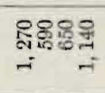 \\
\hline \multirow{5}{*}{ 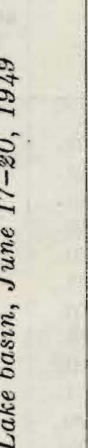 } & 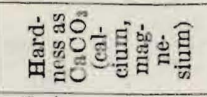 & 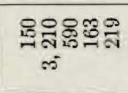 & 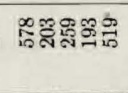 & 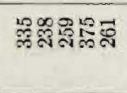 & 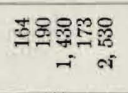 & 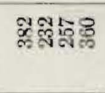 \\
\hline & 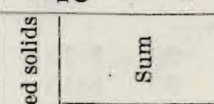 & 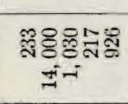 & 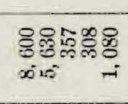 & 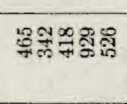 & 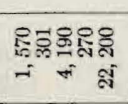 & 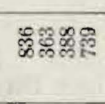 \\
\hline & 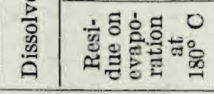 & 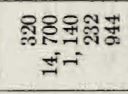 & 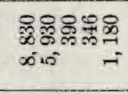 & \% & 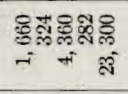 & 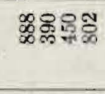 \\
\hline & 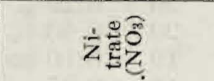 & 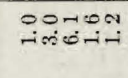 & 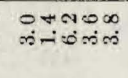 & $\begin{array}{l}\mathrm{N}-\infty 0 \\
\text { Nimis os }\end{array}$ & 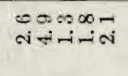 & 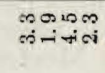 \\
\hline & 혈욜 & Nָ & $\infty$ & $\because$ & ?. & s \\
\hline \multirow{3}{*}{ 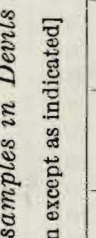 } & 홍류류 & 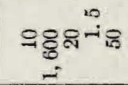 & 잉ํํ & iभม & 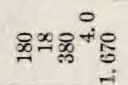 & 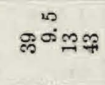 \\
\hline & 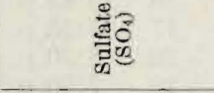 & 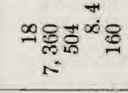 & 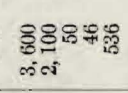 & 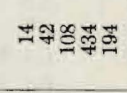 & 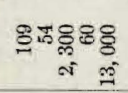 & 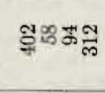 \\
\hline & 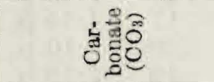 & लाR०० & 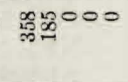 & 00000 & $\mathscr{g}_{0}$ & $000 \mathrm{Z}$ \\
\hline 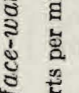 & 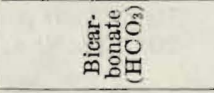 & 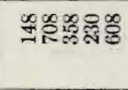 & 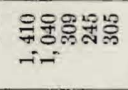 & 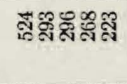 & 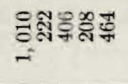 & 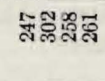 \\
\hline 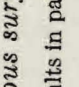 & 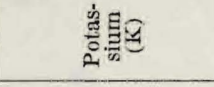 & ${ }_{\infty}^{\infty}$ & त्र & வீ○の & 웅ำ & 廿ம் \\
\hline$\frac{\overrightarrow{\mathrm{g}}}{\mathrm{d}}$ & 施䨔 & 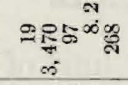 & 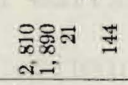 & 심초유ำ & 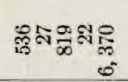 & 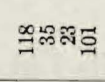 \\
\hline . & 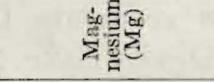 & 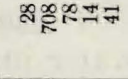 & 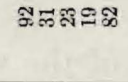 & 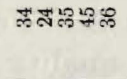 & 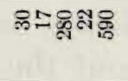 & พฌะเ \\
\hline & 离苜可 & 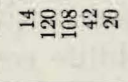 & ฉอีญษ & 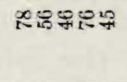 & ஜำ극 & ㅊ:1885 \\
\hline & 릉 & 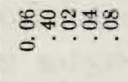 & 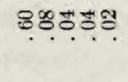 & 웡영영영 & 59899 & 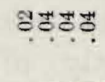 \\
\hline & 涩气 & 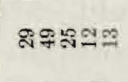 & ตละสล & 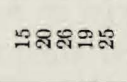 & ตีニッฐュ & $\pm \approx \$^{\circ}$ \\
\hline & 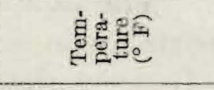 & B\&RB & 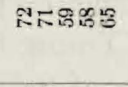 & 98893 & $\not \mathfrak{B}: \mathbb{8}$ & to 88 \\
\hline & 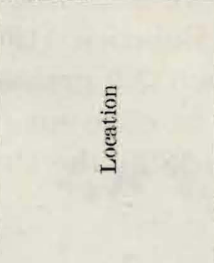 & 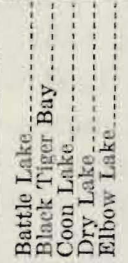 & 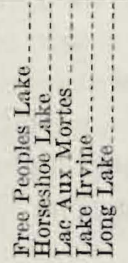 & 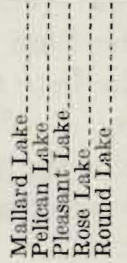 & 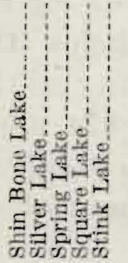 & 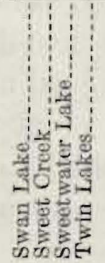 \\
\hline
\end{tabular}


TABLE 4.-Sampling data for miscellaneous lake and surface waters, Devils Lake basin

\begin{tabular}{|c|c|c|c|c|c|c|}
\hline \multirow[b]{2}{*}{ Name } & \multicolumn{3}{|c|}{ Sampling point } & \multicolumn{2}{|c|}{ Sampling period } & \multirow{2}{*}{$\begin{array}{l}\text { Depth, } \\
\text { in feet, } \\
\text { at sam- } \\
\text { pling } \\
\text { point }\end{array}$} \\
\hline & $\begin{array}{l}\text { Town- } \\
\text { ship }\end{array}$ & Range & Section & $\begin{array}{l}\text { Date } \\
\text { (June } \\
\text { 1949) }\end{array}$ & Time & \\
\hline Battle Lake. & 150 & 62 & $\mathrm{SE}_{1 / 4}^{1} \mathrm{NE}_{1 / 4} 17$ & 20 & $5: 20$ p. $\mathrm{m}$. & 2. 6 \\
\hline Black Tiger Bay & 152 & 63 & $\mathrm{SE}^{1} / 4 \mathrm{NE} 1 / 419$ & 20 & $8: 45$ p. m. & 5 \\
\hline Coon Lake... & 152 & 60 & $\mathrm{NE}^{1 / 4} \mathrm{NE}^{1 / 4} 19$ & 20 & $3: 45$ p. m. & 1. 9 \\
\hline Dry Lake.. & $15 \overline{5}$ & 65 & $\mathrm{SE}^{1} 1 / 4 \mathrm{SE}^{1} / 43$ & 19 & $8: 05$ p. m. & 3. 0 \\
\hline Elbow Lake & 151 & 63 & SW $1 / 4$ NW $^{1} / 416$ & 20 & $6: 25$ p. m. & 2. 1 \\
\hline Free Peoples Lake. & 151 & 63 & $\mathrm{NW}^{1 / 4} \mathrm{NW}^{1 / 416}$ & 20 & $6: 20$ p. m. & 1. 7 \\
\hline Horseshoe Lake. & 150 & 64 & $\mathrm{NE}^{1 / 4} \mathrm{SW} 1 / 41$ & 20 & 6:50 p. m. & 1.8 \\
\hline Lac Aux Morte & 156 & 66 & $\mathrm{SW}^{1 / 4} \mathrm{NE}^{1 / 43}$ & 19 & $3: 10$ p. m. & 1. 0 \\
\hline Lake Irvine_ & 156 & 66 & $\mathrm{SW}^{1} / 4 \mathrm{SW}^{1 / 4} 19$ & 19 & $2: 35$ p. m. & 1. 1 \\
\hline Long Lake & 152 & 67 & $\mathrm{SE}^{1 / 4} \mathrm{NW}^{1 / 4} 4$ & 20 & 11:00 a. m. & 2. 0 \\
\hline Mallard Lake & 151 & 64 & $\mathrm{SE}^{1 / 4 \mathrm{SE}^{1} / 414}$ & 20 & $8: 10$ p. m. & 8 \\
\hline Pelican Lake. & 154 & 67 & $\mathrm{SE}^{1} / 4 \mathrm{SE}^{1} / 424$ & 20 & $10: 00$ a. m. & 8 \\
\hline Plea & 156 & 71 & $\mathrm{SE}^{1 / 4 \mathrm{SW}^{1 / 49}}$ & 17 & $7: 45$ p. m. & 2. 3 \\
\hline Rose Lake & 152 & 61 & SW $1 / 4 \mathrm{SW}^{1 / 4} 10$ & 20 & $4: 30$ p. m. & 2. 3 \\
\hline Round Lake & 153 & 67 & $\mathrm{NE}^{1 / 4} \mathrm{SE} 1 / 435$ & 20 & $10: 45$ a. m. & 1. 9 \\
\hline Shin Bone Lak & 151 & 63 & $\mathrm{SE}^{1 / 4} \mathrm{NW}^{1 / 434}$ & 20 & $5: 45$ p. m. & 1. 6 \\
\hline Silver Lake...... & 155 & 67 & $\mathrm{SE}^{1 / 4} \mathrm{NW}^{1 / 4} 34$ & 17 & 5:35 p. m. & 2. 5 \\
\hline Spring Lake_- & 152 & 64 & $\mathrm{SW}^{1} 1 / 4 \mathrm{NE}^{1} 1 / 435$ & 20 & $8: 30$ p. m. & 1. 6 \\
\hline Lake. & 151 & 64 & $\mathrm{SE}_{1 / 4} \mathrm{SE}_{1 / 4}^{111}$ & 20 & $7: 50$ p. m. & 1. 9 \\
\hline Stink Lake_. & 155 & 67 & NW1/4NW $1 / 414$ & 17 & $4: 45$ p. m. & 5 \\
\hline Swan Lake & 152 & 61 & $\mathrm{NE}^{1} / 4 \mathrm{NE} 1 / 427$ & 20 & $4: 10$ p. m. & 2. 3 \\
\hline t Creek & 156 & 63 & $\mathrm{SE}^{1} / 4 \mathrm{SE}_{1} / 413$ & 19 & $7: 15$ p. m. & 1. 2 \\
\hline Sweetwater Lal & 155 & 64 & $\mathrm{SE}^{1} / 4 \mathrm{NW}^{1} / 427$ & 19 & $8: 30$ p. m. & 2. 5 \\
\hline Twin Lakes .... & 152 & 66 & $\mathrm{SE}^{1 / 4} \mathrm{SW} 1 / 422$ & 20 & $11: 50$ a. $\mathrm{m}$. & 1. 9 \\
\hline
\end{tabular}

1 Sample collected from marsh adjacent to lake.

\section{DEVILS LAKE}

Devils Lake is the most important unit of the waterway system in the Devils Lake basin. For over 50 years residents have been concerned about the quality of the water in Devils Lake. Much of this concern is related to problems of restoring the recreational value of the lake, especially the fish and wildlife resources.

Devils Lake is the repository of water from Mauvais Coulee and, indirectly, of flows from the Sweetwater group of lakes. Present water in Devils Lake is, in a sense, "old" Mauvais Coulee water that has been concentrated through evaporation and has lost its former chemical character and fresh-water properties. The lake water was brackish as early as 1899, as Young (1924) reports a concentration of dissolved solids for that year of $8,471 \mathrm{ppm}$. In 1899 the lake level was 14 feet below the high mark of 1867 . Babcock (1903) stated that the salinity of the lake water in 1902 was 635.9 grains per U.S. gallon, or 10,874 ppm, a substantial increase in concentration. Because the lake stage was slightly higher than in 1899, the 1902 concentration appears to be questionable. 
TABLE 5.-Chemical analyses of water samples from Mauvais Coulee near Churchs Ferry

[Analytical results in parts per million except as indicated]

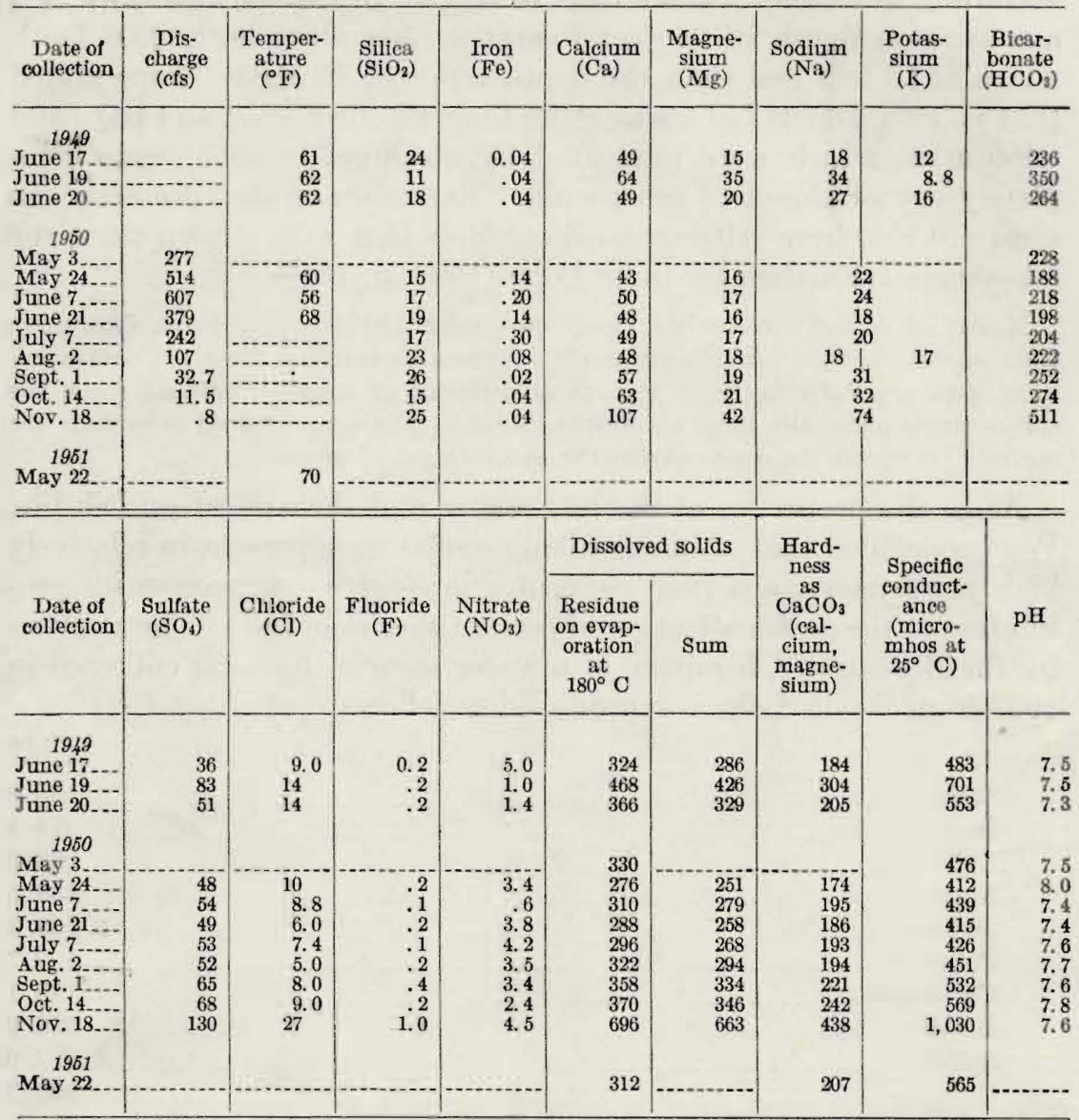

Pope (1909) made the earliest detailed investigation of the chemical and physical properties of water in Devils Lake in the 7-week period from July 20 to September 10, 1907. Pope and his colleagues of the U. S. Bureau of Fisheries sought to explain the cause of the sudden disappearance of pike from Devils Lake about 1889 and to determine the possibility of restocking the lake with suitable fish in response to urgent requests from local residents. Through arrangements made the year before his visit, Pope obtained a sample of water from Creel Bay, an arm of Devils Lake, and reported the concentration of salts as of June 1906 to be 8,517 ppm. During fieldwork in 1907 he collected samples from several parts of the lake and reported the concentration in the main lake (identified as station 5, large lake) to be 
9,448 ppm, as calculated from the sum of measured constituents. Density of water in Devils Lake in 1907 varied from 1.0054 to 1.0090 , according to locality. Soundings in August of the same year showed a maximum depth of 25 feet (water surface altitude, 1,423.6 feet), which is 10 feet less than the depth reported in 1883. Pope stated that in 1907 Devils Lake was at its lowest known level and bays and tributaries, which were navigated by steamers in 1883, were completely dry or closed to navigation. Recession of the lake area was apparent also from salt-incrusted boulders that were strewn along the lakeshores. Further, to quote Pope $(1909$, p. 16)-

Nearly all of the surrounding lands, especially the "dried up" bays, show upon their surface a thin grayish-white efflorescence resembling frost. These accumulations, generally found in regions of deficient or irregular rainfall when the soil contains unusually large amounts of soluble salts concentrated in or near the surface, represent the residue from the evaporation of moisture.

As to the properties of the lake water and their effect on fish life, Pope concluded that although alkaline salts were present in relatively high percentages, observed concentrations were not necessarily prohibitive to the acclimatization of certain species of fish. The analysis by the Bureau of Chemistry of a water sample that was collected in 1907 from Devils Lake is reproduced as follows:

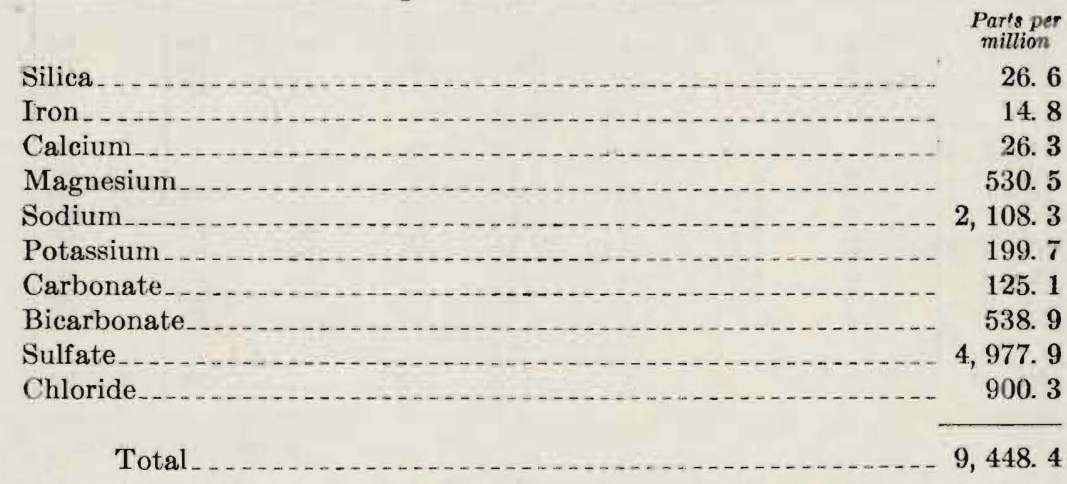

Four years after the investigation by the Bureau of Fisheries, Daudt (1911) published an analysis of the lake water that showed the concentration of dissolved solids in 1911 to be $11,278 \mathrm{ppm}$. The level of Devils Lake had declined more than 3 feet during those 4 years. In 1914 and 1918 the salinity of the lake water was 12,092 and $14,452 \mathrm{ppm}$, respectively, according to Nerhus. ${ }^{2}$ The concentration had decreased to $13,462 \mathrm{ppm}$ in 1919 (Young, 1924) when the stage of Devils Lake had increased approximately 1 foot above the 1918 reading.

\footnotetext{
2 Nerhus, P. T., 1920, A study of solubility relations of the salts in Devils Lake water: Thesis for Master of Sei. Degree, N. Dak. Univ., p. 4.
} 
By 1920 the water had become more saline; Nerhus ${ }^{3}$ reported a concentration of $15,889 \mathrm{ppm}$ and a density of 1.0101 at $23^{\circ} \mathrm{C}$. The lake water was brackish, and salts of sodium and magnesium were the principal compounds in solution. Nerhus noted that sulfate rather than chloride was the chief acid radical in the water, and in this respect Devils Lake was unlike many western lakes, such as Searles Lake, Cadiz Lake, and Owens Lake in California and Dixie Salt Marsh in Nevada, whose waters contain chloride in excess of sulfate. Nerhus also mentioned the low calcium content of Devils Lake water and the negligible concentration of iron. During the subsequent 3 years, fluctuations in water level were small; and in 1923 the concentration of the dissolved solids in the lake water was 15,210 ppm, according to Young (1924).

To summarize early salinity studies of Devils Lake, the concentration of salts in the water had almost doubled (from 8,471 to 15,889 $\mathrm{ppm}$ ) in the 24 years from 1899 to 1923 . During this same period the lake surface had fallen about 8 feet. In the succeeding 25 years, from 1923 to the beginning of the quality-of-water study by the Geological Survey in 1948, no investigations of the salinity of the lake water are known to have been made. The surface of Devils Lake declined during the period 1923 to 1940 , until an altitude of $1,400.9$ feet, the lowest recorded stage, was reached in 1940. At this time the average depth of the lake was about 2 feet, and the lake surface was 38 feet lower than in 1867 . The area of the lake had shrunk from about 90,000 acres in 1867 to 6,500 acres in the main lake in 1940 (North Dakota, 1944, p. 23). Unfortunately, no data. as to salinity of the lake water in 1940 are available, but no doubt the lake water was more concentrated than it had ever been before.

The period 1948 to 1952.-The investigation by the Geological Survey of the quality of surface water in Devils Lake basin included the following: The present salt concentration and properties of the lake waters, the degree to which salinity of the waters could be reduced by inflow of fresh water from outside the basin, the volume of inflow and outflow that would be required to maintain low concentrations of salts, the properties of the natural and diverted inflow waters, estimates of the tonnages of salts that might be redissolved from deposits along the shorelines when lake levels are raised, the character of bed sediments in the lakes, the presence of toxic metals in the water, and the quality of present Sheyenne River water. Many details pertaining to the construction, operation, and maintenance of a series of proposed canals for restoration of lake levels depend on quality-of-water information.

3 Idem, p. 4-5. 
In November 1948 the salt concentration of Devils Lake was $25,000 \mathrm{ppm}$, the highest measured during the period of study. The lake had risen 3 feet since the low stage of 1940. As no analysis of the lake water had been made for many years, to the writers' knowledge, the chemical character of the water in late 1948 was compared with that in earlier years to observe any changes in composition. For this comparison the analysis by Daudt (1911) was used. In the following table analyses of Devils Lake water for 1911 and 1948 are reported in percentage of the dry salt residue.

\section{Percentage composition of water in Devils Lahe}

\begin{tabular}{|c|c|c|}
\hline & 1911 & 1948 \\
\hline Calcium $(\mathrm{Ca})$ : & $\ldots \ldots$ & 0. 4 \\
\hline Magnesium $(\mathrm{Mg}) \ldots \ldots \ldots \ldots$ & 5. 4 & 5. 7 \\
\hline Sodium (Na) & 25.9 & 24. 7 \\
\hline Carbonate $\left(\mathrm{CO}_{3}\right)_{1}$ & 4. 2 & 2. 9 \\
\hline Sulfate $\left(\mathrm{SO}_{4}\right)_{1}$ & 54. 1 & 54. 4 \\
\hline Chloride $(\mathrm{Cl})_{\ldots} \ldots$ & 10. 5 & 11.5 \\
\hline . & 11,278 & 25,000 \\
\hline
\end{tabular}

The percentage composition of the lake water in $194 \mathrm{~s}$ is almost identical to that reported by Daudt 37 years earlier. Thus, the relationship of ions in the lake water has remained reasonably constant even though the concentration of salts has more than doubled.

In May 1949 Mauvais Coulee was discharging fresh water into Devils Lake; a measurement of 385 cubic feet per second (cfs) was recorded on May 10. As a result of mixing of lake and coulee waters, the salinity of the lake water as determined from one sample on May 19 was reduced to $17,300 \mathrm{ppm}$, a concentration much less than that of November 1948.

From June 14 to 18,1949 , a detailed investigation was made to determine the areal and vertical variations in the chemical character of the water in Devils Lake. Thirty-two samples of water were collected at different points in the lake for chemical analysis. Because the lake was shallow (the maximum measured depth, 6.9 feet; altitude, 1,406 feet), most of these samples were integrated throughout the depth. At 4 places in the lake, however, at depths from 3.9 to 6.9 feet, separate samples were collected from points near the bottom and near the surface. At each sampling location, soundings were made and water temperatures recorded. Sediments from the lake bottom were analyzed for particle sizes.

The average density of the water in June 1949 was 1.009 grams per milliliter at $20^{\circ} \mathrm{C}$. The composition of Devils Lake water was uniform over the entire lake, but the concentration varied slightly. The map in figure 12 shows that concentrations in Creel Bay are 
slightly lower than those in the main part of the lake. Whereas the average salinity of the lake during this detailed study was 13,400 ppm, samples from Creel Bay averaged about 3 percent less than this concentration. The discharges of untreated sewage from the city of Devils Lake explains the lower concentration of salts, probably by dilution, and the higher concentrations of nitrate $\left(25 \mathrm{ppm} \mathrm{NO}_{3}\right.$ maximum) in Creel Bay. The slightly lower than average concentration near the southwestern shore of the lake may be due to a mixture of lake water with discharge from small springs. Variation in concentration of lake water from top to bottom was not significant, except in one location near the western shore of the lake where top and bottom samples measured 13,200 and $14,700 \mathrm{ppm}$, respectively, a difference of about 10 percent on the basis of the denser water. The lake water was alkaline; the $\mathrm{pH}$ ranged from 8.0 to 8.7 and averaged 8.3 and 8.4 on June 14 and 18 , respectively.

The reason for the disappearance of fish in Devils Lake has been a matter of speculation since 1889. Abbott (1924, p. 183-184) offered the explanation that fish species in the lake died because of toxic substances in the water. After careful chemical examination of the lake water, he reported the presence of zinc in concentrations of about $15 \mathrm{ppm}$ and presented experimental evidence to show that fish could not survive in water of this concentration of zinc. Analyses of the lake water by the Geological Survey in 1949 and subsequent years show zinc in trace amounts only; the maximum concentration observed was $0.16 \mathrm{ppm}$. An independent examination by Abbott at the time of the present investigation reported zinc in concentration of 0.20 ppm and confirmed the measurement of the Geological Survey. These data strongly suggest that, during the interval between 1924 and the present study, the zinc ions originally present must have reacted chemically with other ions in the water and precipitated as an insoluble zinc compound, probably zinc sulfide. Shortly after Abbott's studies in 1924, the city of Devils Lake began discharging raw sewage into the shallow and receding waters of Creel Bay. While the lake level continued to fall, the untreated sewage decomposed as a result of bacterial fermentation and emitted hydrogen sulfide; the presence of this gas was readily verified during the 1949 study. Hydrogen sulfide in an alkaline solution, such as Devils Lake water, will precipitate soluble zinc compounds to form insoluble zinc sulfide. Zinc soaps might also be precipitated, as domestic sewage is charged with considerable quantities of soaps. In 1949 the altitude of Devils Lake was about 10 feet lower than in 1924 . In 1949 and 1950 analyses of salt from encrusted rocks and soils that were exposed along former shorelines showed conclusive evidence of zinc. The percentage of zinc in salt incrustations on the basis of 3 samples from widely scat- 


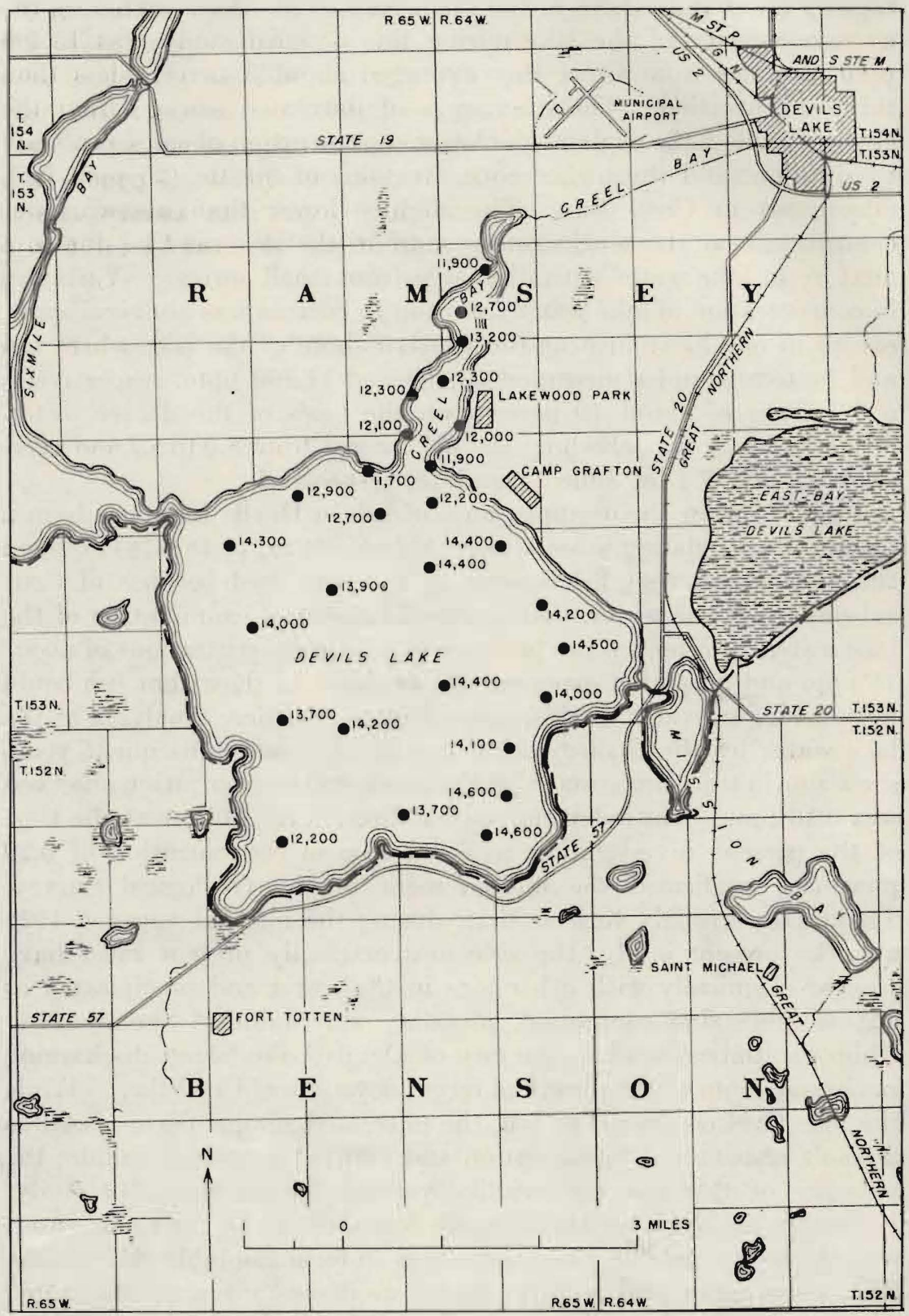

Figure 12.-Map of Devils Lake showing areal concentration of salts in parts per million, June 14-18, 1949 
tered localities was 6 to 15 times as much as the percentage of zinc in the dry salt residue of a sample of lake water in September 1950. These facts suggest that most of the zinc, at one time present in the water in significant concentrations, has been chemically precipitated on the lake floor; as the lake recedes, the exposed rocks and soil particles show this evidence.

Analyses for trace elements were made by the Geological Survey from 1948 to 1952 ; and as the following table shows, the concentrations of these elements in Devils Lake water are very low.

Observed maximum concentrations of trace elements in water of Devils Lake, 1948-52

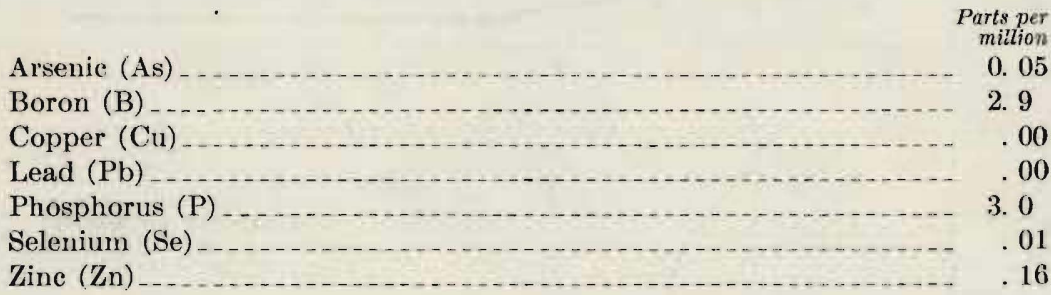

The floor of Devils Lake is composed mostly of clayey silt except in certain parts of the lake, particularly Creel Bay, where the floor is covered with a black ooze from sewage. Density and size analyses are given in the following table for six samples of lakebed sediments from different parts of the le.ke.

Density and size analyses of lakebed sediments

\begin{tabular}{|c|c|c|c|c|c|}
\hline \multirow[b]{2}{*}{ Location } & \multirow{2}{*}{$\begin{array}{l}\text { Density } \\
(\mathrm{g} / \mathrm{ml} \text { at } \\
\left.20^{\circ} \mathrm{C}\right)\end{array}$} & \multicolumn{4}{|c|}{ Percent in indicated size range } \\
\hline & & Sand ${ }^{1}$ & Silt 2 & Clay $^{3}$ & $\begin{array}{l}\text { Colloidal } \\
\text { clay } 4\end{array}$ \\
\hline $\begin{array}{l}\text { SW1/4 sec. } 7 \text {, T. } 153 \text { N., R. } 64 W_{-} \\
\text {SE1/4 sec. } 24, \text { T. } 153 \text { N., R. } 65 \text { W. } \\
\text { SE1/4 sec. } 31 \text { T. } 153 \text { N. R. } 64 \text { W }\end{array}$ & $\begin{array}{l}\text { 2. } 51 \\
\text { 2. } 58 \\
2.63\end{array}$ & $\begin{array}{r}3.8 \\
3.3 \\
99.8\end{array}$ & $\begin{array}{l}52.7 \\
70.8\end{array}$ & $\begin{array}{r}\text { 12. } 9 \\
7.8\end{array}$ & $\begin{array}{l}30.6 \\
18.1\end{array}$ \\
\hline SW1/4 sec. 1 , T. 152 N., R. 65 W. & 2. 66 & 7.1 & 57.2 & 8. 8 & 26. \\
\hline NE $1 / 4$ sec. 34 , T. 153 N., R. 65 W- & 2. 63 & 9. 7 & 60.9 & 10. 2 & 19. 2 \\
\hline SE $1 / 4$ see. 36 , T. 153 N., R. 65 W- & 2. 57 & .9 & 52. 9 & 11. 3 & 34. $\overline{9}$ \\
\hline
\end{tabular}

$1.0-0.0625 \mathrm{~mm} . \quad 20.0625-0.0039 \mathrm{~mm} . \quad 30.0039-0.00195 \mathrm{~mm} . \quad+<0.00195 \mathrm{~mm}$.

The chemical and physical properties of water in Devils Lake were modified considerably in 1950, when, during the water year ending September 30, 1950, precipitation was well above average (fig. 2) and Devils Lake rose about 8 feet. No larger rise during any one year is known. The mixing of lake water with runoff, mostly snowmelt, improved the quality of the water (fig. 13). By December 9, 

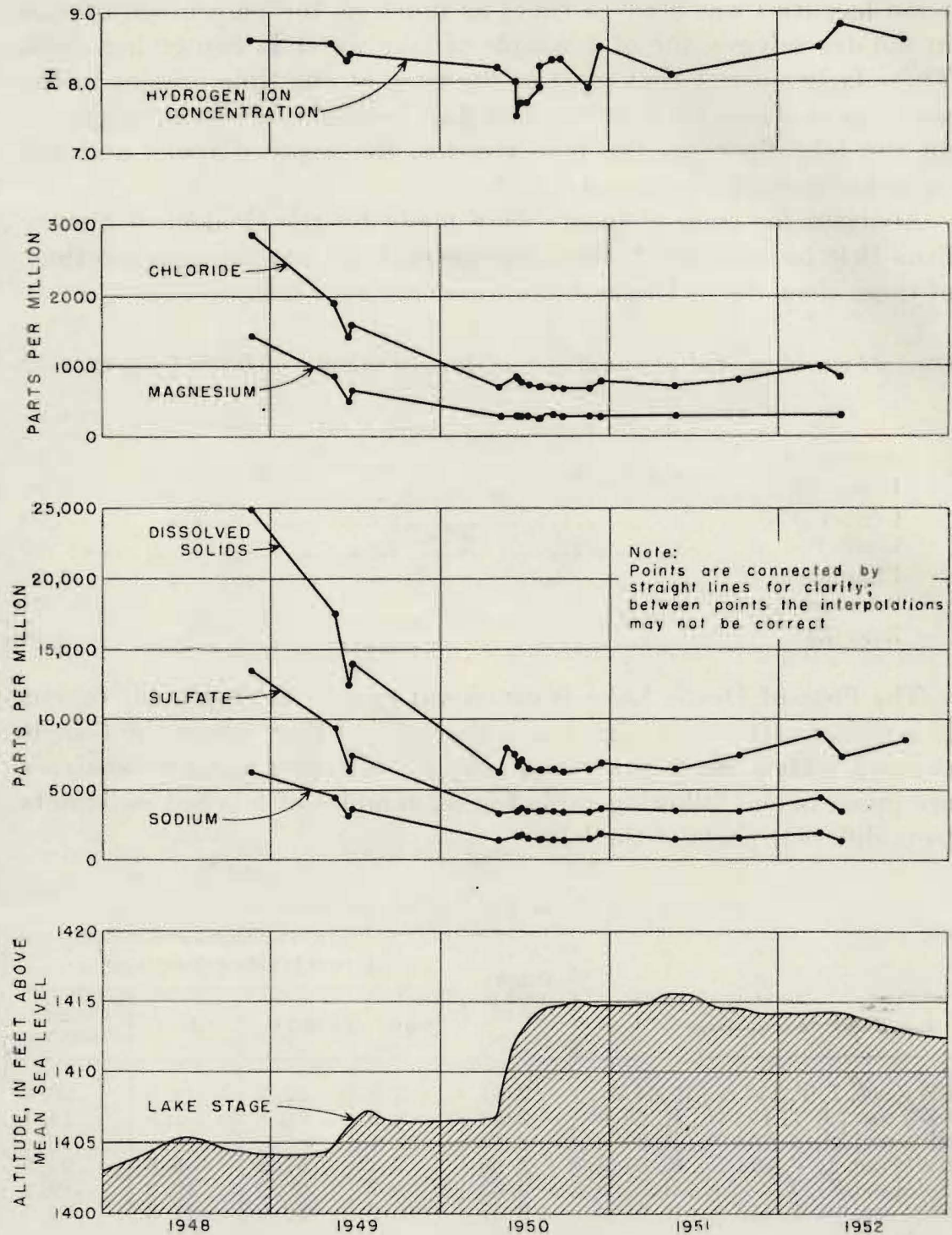

Figure 13.-Effects of fluctuation in stage on chemical character of water in Devils Lake, 1948-52.

1950 , the salinity of the water $(6,990 \mathrm{ppm})$ had decreased more than 50 percent since June 18, 1949- the last date that samples were collected during that year. The concentration of dissolved solids in 19 samples obtained in 1950 , ranged from 6,130 to $8,140 \mathrm{ppm}$. The lake water was less alkaline much of this time; the $\mathrm{pH}$ dropped to 7.5 in the middle of June. 
In August 1950 several small springs near Devils Lake were visited to obtain information on ground-water discharge. The waters were much fresher than Devils Lake water, but flows were small. Estimated discharges and general properties of three spring waters are given in the following table.

Properties of spring waters near Devils Lake

\begin{tabular}{|c|c|c|c|c|c|}
\hline \multirow[b]{2}{*}{$\begin{array}{c}\text { Date } \\
\text { sampled } \\
(1950)\end{array}$} & \multirow[b]{2}{*}{ Location of spring } & \multirow[b]{2}{*}{$\begin{array}{c}\text { Esti- } \\
\text { mated } \\
\text { flow } \\
\text { (gpm) }\end{array}$} & \multirow[b]{2}{*}{$\mathrm{pH}$} & \multicolumn{2}{|c|}{ Parts per million } \\
\hline & & & & $\begin{array}{l}\text { Dissolved } \\
\text { solids } \\
\text { (residue } \\
\text { on evap- } \\
\text { oration } \\
\text { at } 180^{\circ} \mathrm{C} \text {.) }\end{array}$ & $\begin{array}{c}\text { Hardness } \\
\text { as CaCo } \\
\text { (calcium, } \\
\text { magne- } \\
\text { sium) }\end{array}$ \\
\hline Aug. $\begin{array}{r}1 \\
1 \\
3\end{array}$ & $\begin{array}{l}\text { Fort Totten Indian Reservation } \\
\text { East Bay of Devils Lake } \\
\text { Fort Totten Indian Reservation }\end{array}$ & 1 & $\begin{array}{l}\text { 7. } 2 \\
\text { 7. } 3 \\
\text { 7. } 5\end{array}$ & $\begin{array}{r}808 \\
11,000 \\
398\end{array}$ & $\begin{array}{l}296 \\
637 \\
258\end{array}$ \\
\hline
\end{tabular}

isum.

Many years ago, certainly in 1867 when Devils Lake was at its: highest known level of 1,438 feet above mean sea level, the water in the lake was fresh; and the proportions of calcium and bicarbonate to other ions must have been much greater than in 1953. Incrustations on rocks and pebbles now exposed along the shore are essentially calcium carbonate, as shown by the following analyses of salt incrustations from three rock specimens.

Analyses of salt incrustations on exposed rocks

\begin{tabular}{|c|c|c|c|}
\hline $\begin{array}{l}\text { Date } \\
\text { samaples } \\
\text { (1950) }\end{array}$ & Type of material & Location & $\begin{array}{l}\text { Percent cal- } \\
\text { cium carbon- } \\
\text { ate }\left(\mathrm{CaCO}_{3}\right)\end{array}$ \\
\hline Aug. $\begin{array}{r}1 \\
2 \\
2\end{array}$ & $\begin{array}{l}\text { Cobble } \\
\text { Cobble } \\
\text { Pebble }\end{array}$ & $\begin{array}{l}\text { Near mouth of Creel Bay } \\
\text { South shore of lake } \\
\text { West shore of lake }\end{array}$ & $\begin{array}{l}96.3 \\
96.5 \\
96.3\end{array}$ \\
\hline
\end{tabular}

In early May of 1951 Devils Lake reached a level of 1,415.5 feet, the highest in 27 years. This altitude was 14.6 feet above the low level of 1940. The salinity of the lake water on May 22, 1951, was $6,680 \mathrm{ppm}$; the composition of the dry solids showed slight increases, compared to the sample taken during 1948, in calcium and carbonate as the result of dilution by fresh waters from Mauvais Coulee during the period of 1949-51. To illustrate these changes the analyses of 1911 (Daudt, 1911) and 1948 are retabulated, together with the analysis of May 1951. 
Percentage composition of Devils Lake water

\begin{tabular}{|c|c|c|}
\hline & 1911 & 1948 \\
\hline Calcium $(\mathrm{Ca})$ & $\ldots$ & 0.4 \\
\hline Magnesium $(\mathrm{Mg}) \ldots$ & 5. 4 & 5. 7 \\
\hline Sodium (Na) & 25. 9 & 24. 7 \\
\hline Carbonate $\left(\mathrm{CO}_{3}\right)$ & 4. 2 & 2. 9 \\
\hline lffate $\left(\mathrm{SO}_{4}\right) \ldots$ & 54. 1 & 54. 4 \\
\hline hloride $(\mathrm{Cl}) \ldots$ & 10. 5 & 11. 5 \\
\hline
\end{tabular}

Salinity ppm

$11,278 \quad 25,000 \quad 6,680$

The lake level declined gradually from the end of May 1951 to December 1952; and on January 11, 1953, the altitude of Devils Lake $(1,412.5$ feet) was 3 feet below the peak of 1951. Analyses of the water in May and October 1952 show salt concentrations of 7,300 and $8,680 \mathrm{ppm}$, respectively, and the present trend (1953) is a general decline in lake levels and a gradual increase in salinity of the water. The density of the lake water in March 1952 was 1.004 grams per milliliter at $20^{\circ} \mathrm{C}$.

The chemical and physical properties of water in Devils Lake from late 1948 to October 1952 are summarized as follows: Salinity has ranged from 6,130 to $25,000 \mathrm{ppm}$, and the lake water has been moderately to very alkaline; concentration has varied according to volume of lake water, but the chemical character as shown by the percentage composition of mineral constituents in the water has remained uniform; and a slight modification in proportion of constituents followed periods of high inflow of Mauvais Coulee water. The analyses of samples that were collected from 1948 to 1952 are reported in table 6 .

\section{SIXMILE BAY}

Sixmile Bay opens into the northwest part of Devils Lake. The water in this bay is moderately alkaline and is about one-fourth to one-sixth as mineralized as water in the main part of Devils Lake. The concentration in 3 samples of water that were collected in 1949 and 1950 from the bridge on State Route 19 ranged from 1,600 to $2,320 \mathrm{ppm}$. Sixmile Bay also receives drainage water from a small area to the north of the bay, and this local inflow also dilutes the water. Analyses of water in Sixmile Bay are given in table 7 .

\section{EAST BAY DEVILS LAKE}

East Bay Devils Lake during recent years has been a dry lakebed except for Black Tiger Bay and scattered marshes. Early records, from 1899 to 1920, of the concentration of salts in East Bay Devils Lake show a range of 8,471 to $62,929 \mathrm{ppm}$ (Young, 1924). Although most of East Bay Devils Lake was dry in June 1949, a water sample 
EAST BAY DEVILS LAKE

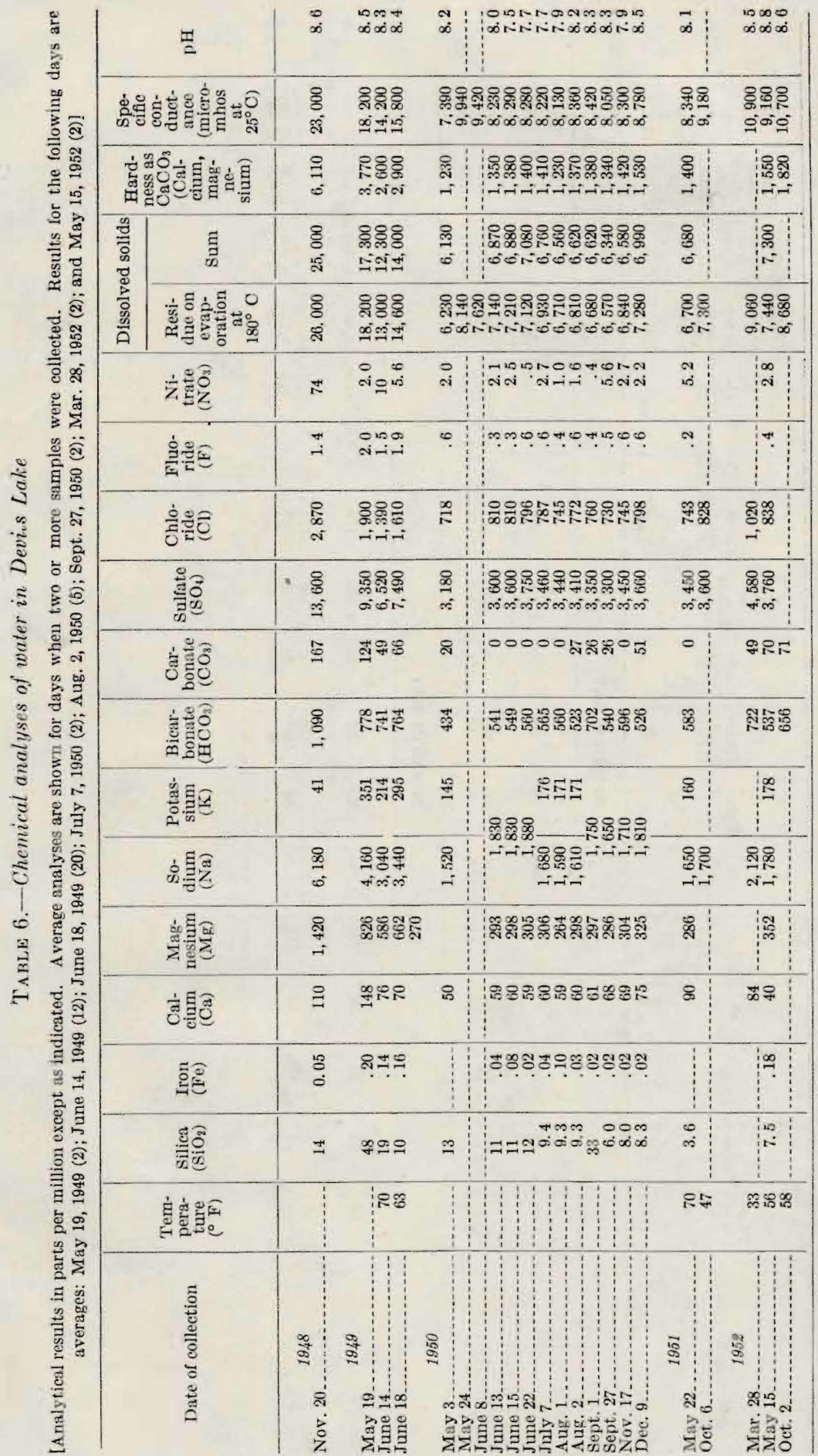




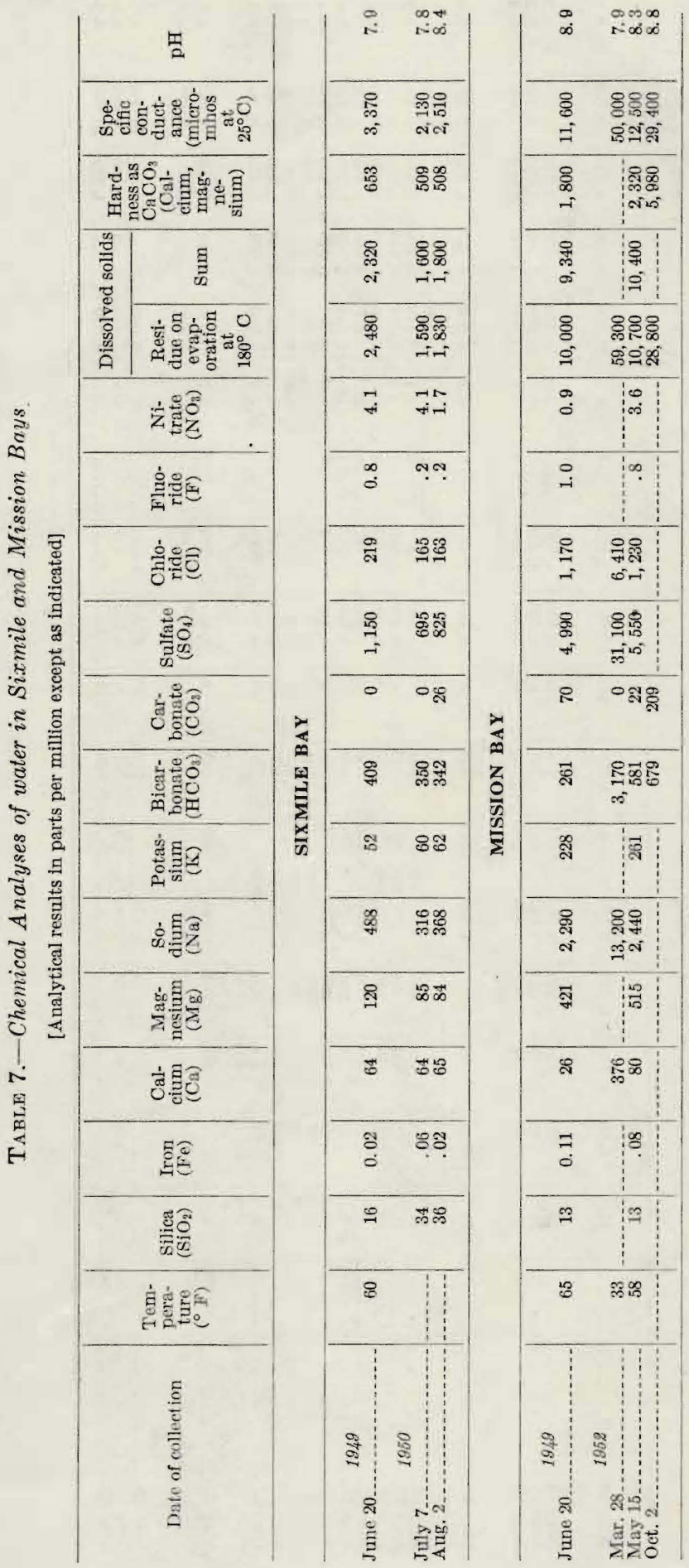




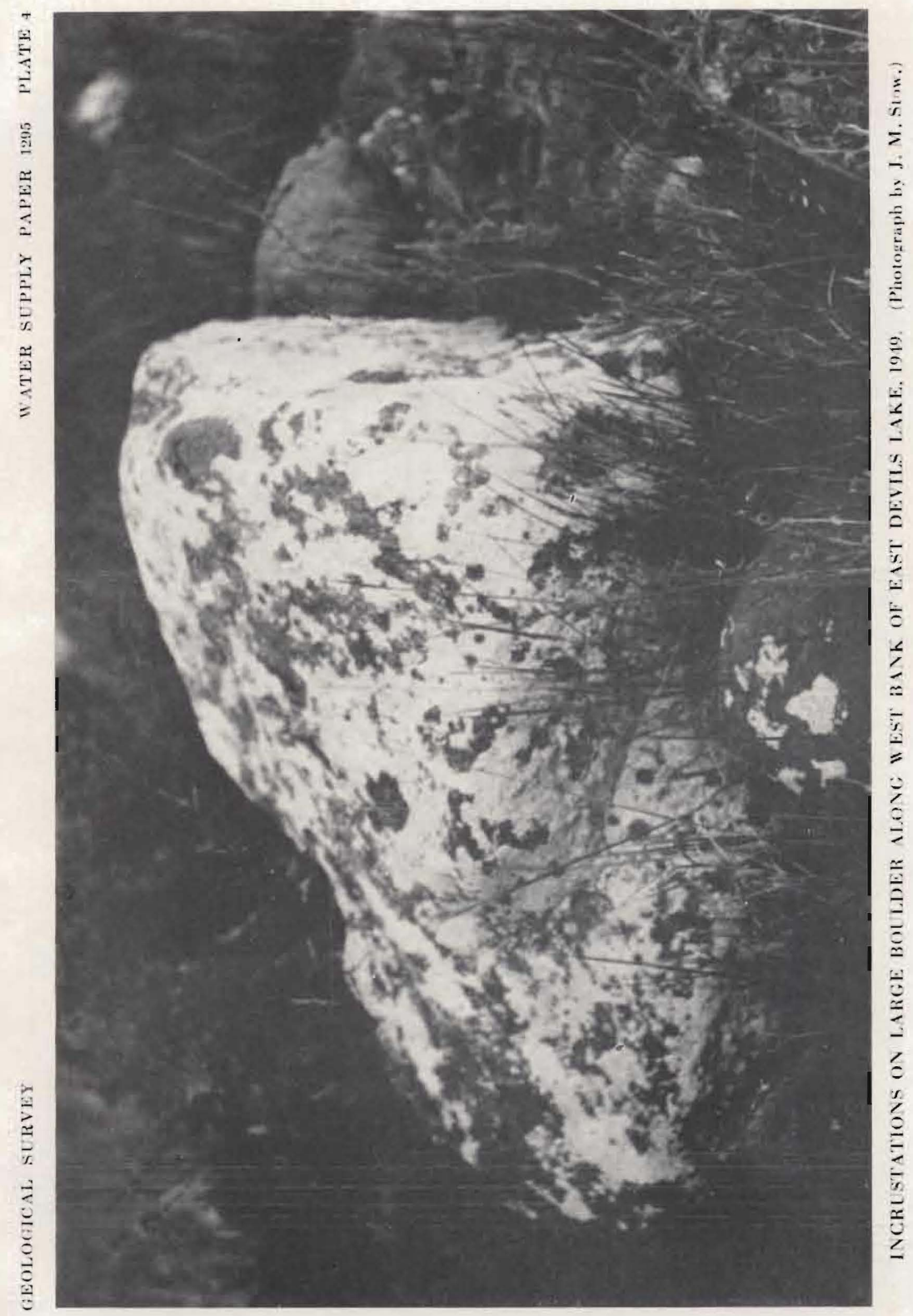


was collected from Black Tiger Bay and the salinity measured as $14,000 \mathrm{ppm}$, which was the same as in Devils Lake at that time. The chemical character of water in Black Tiger Bay was almost identical to that in Devils Lake; an analysis of the water in Black Tiger Bay is reported in table 3.

\section{MISSION BAY}

The small irregularly shaped bay extending from the southeastern part of Devils Lake is Mission Bay. Much of its former area has been cut off as the lake level declined. Records from 1907 to 1920 report salt concentrations that range from 9,218 to $48,179 \mathrm{ppm}$ (Young, 1924). Analyses by the Geological Survey of 4 samples that were collected from June 1949 to October 1952 show a concentration range of 9,340 to $59,300 \mathrm{ppm}$. (See table 7.) This maximum concentration was for a sample taken under thick ice. The water in Mission Bay resembles water of Devils Lake in chemical character.

\section{EAST DEVILS LAKE}

East Devils Lake is an important waterway in the lake system that begins with Devils Lake and ends with east Stump Lake. At one time East Devils Lake was part of Devils Lake, and East Bay Devils Lake was the connection between them. Recession of Devils Lake detached numerous bodies of water, of which East Devils Lake is one.

According to Young (1924) the concentration of salts in the water of East Devils Lake (or Lamoreaux Bay as it was then known) was 14,932 ppm in 1919, slightly higher than that of Devils Lake. Thirty years later, in 1949, the salt concentration of East Devils Lake was $41,100 \mathrm{ppm}$, which was almost 3 times that of Devils Lake. The latter lake benefited from time to time from inflow of fresh water; on the other hand, East Devils Lake, which lies at a lower altitude and has a very flat bed, received little drainage from surrounding land.

On June 18, 1949, samples were collected at several points in East Devils Lake. Soundings and water temperatures were recorded. Analysis of these samples showed that the quality of the water was remarkably uniform throughout the lake. The concentration varied by $800 \mathrm{ppm}$, from 40,500 to $41,300 \mathrm{ppm}$ (fig. 14). The difference between a top and a bottom sample was negligible, and the maximum sounding obtained in the shallow lake was 6 feet. The average density of the lake water was 1.034 grams per milliliter at $20^{\circ} \mathrm{C}$. The properties of the water approximated those of Devils Lake except that the water in East Devils Lake was more alkaline and mineralized.

Measurements of salt concentrations of 5 samples that were collected in 1950 to 1952 ranged from 35,300 to $62,000 \mathrm{ppm}$. This water was.

$326053-55-4$ 


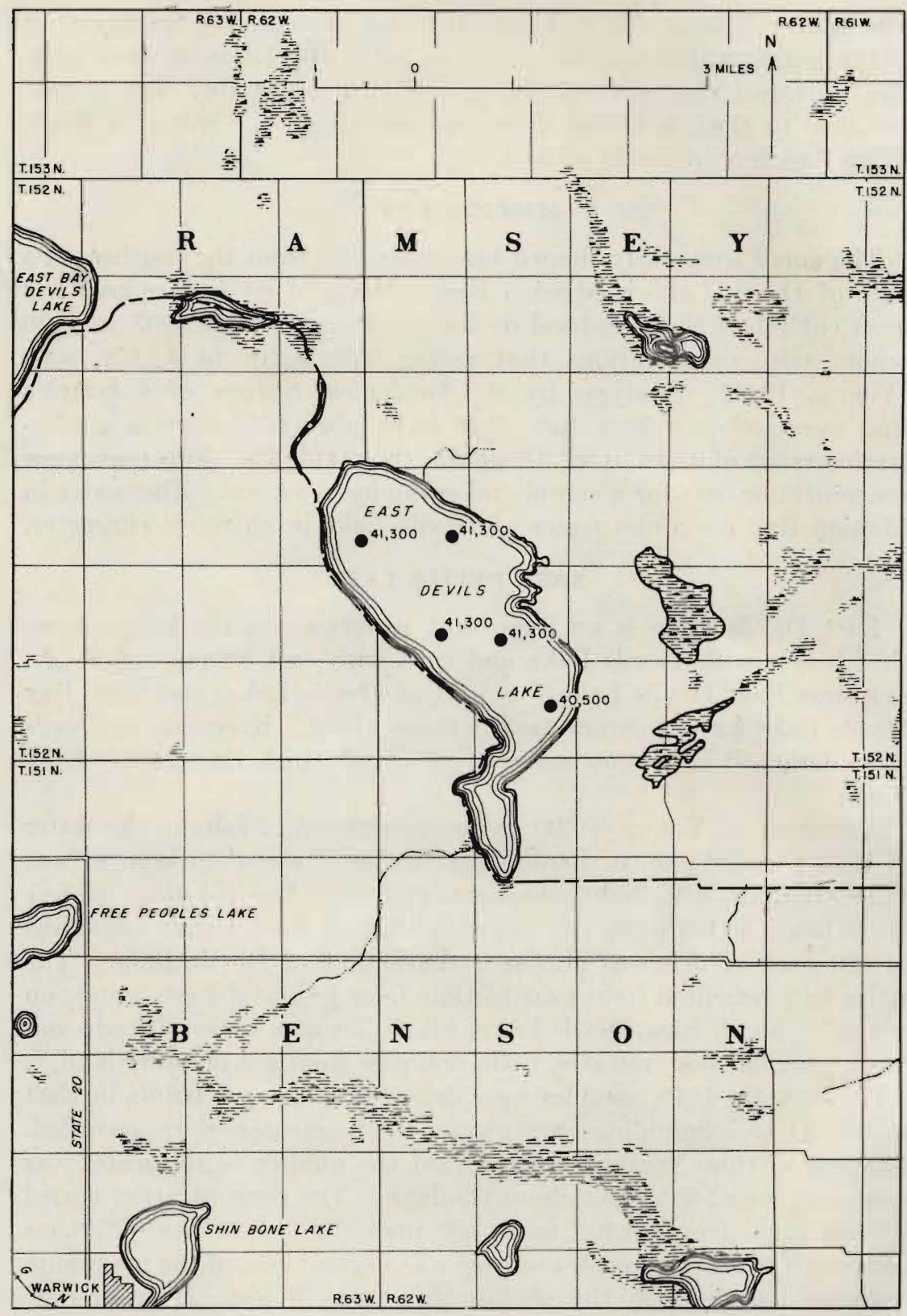

FigURE 14.-Map of East Devils Lake showing areal concentration of salts in parts per million, June 18, 1949. 
decidedly alkaline; a $\mathrm{pH}$ of 9.0 was reported on October 2, 1952. Changes in density with concentration are shown in the following tabulation:

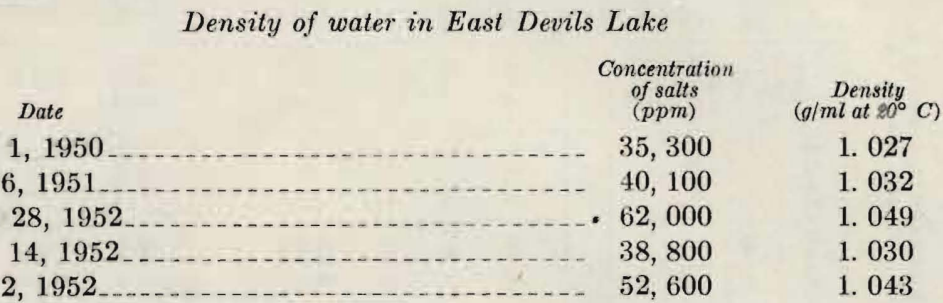

A sample of bed sediment near the center of the lake floor was examined for particle size. This material was classified as clayey silt on the basis of the following analysis:

Size analysis of lakebed sediment

Size range

Percent

Sand $(1.0-0.0625 \mathrm{~mm})$

4. 5

Silt $(0.0625-0.0039 \mathrm{~mm})$

54. 4

Clay $(0.0039-0.00195 \mathrm{~mm})$

11. 0

Colloidal clay $(<0.00195 \mathrm{~mm})$

30. 1

Density $\mathrm{g} / \mathrm{ml}$ at $20^{\circ} \mathrm{C}$

2. 60

Exposed rocks near the shoreline of East Devils Lake show salt incrustations (pl. 4), which were identified as calcareous deposits. Samples of incrustations obtained from rocks along the north and west shores contained 98.9 and 98.7 percent, respectively, calcium carbonate $\left(\mathrm{CaCO}_{3}\right)$.

No springs having appreciable flow are known to feed East Devils Lake. A small seep, which is believed to have flowed into the lake at one time, had a salt concentration of $948 \mathrm{ppm}$, much less than that of the lake. Analyses of water in East Devils Lake from 1949 to 1952 are listed in table 8.

\section{WESTERN STUMP LAKE}

Through recession of lake levels, Stump Lake separated many years ago into two lakes, which are now divided by a highway embankment. The two lakes are approximately 10 miles southeast of East Devils Lake. The Federal government has set aside several islands in west Stump Lake as a wildlife refuge for game birds and migratory fowl.

The chemical character of the water in west Stump Lake is similar to that of water in other major lakes of the closed basin including east Stump Lake; however, the concentration of salts is much less. With the exception of a single sample that was collected under ice in March 1952, the salt concentration of this lake ranged from 2,410 to 
CHEMICAL QUALITY OF SURFACE WATERS, DEVILS LAKE BASTN

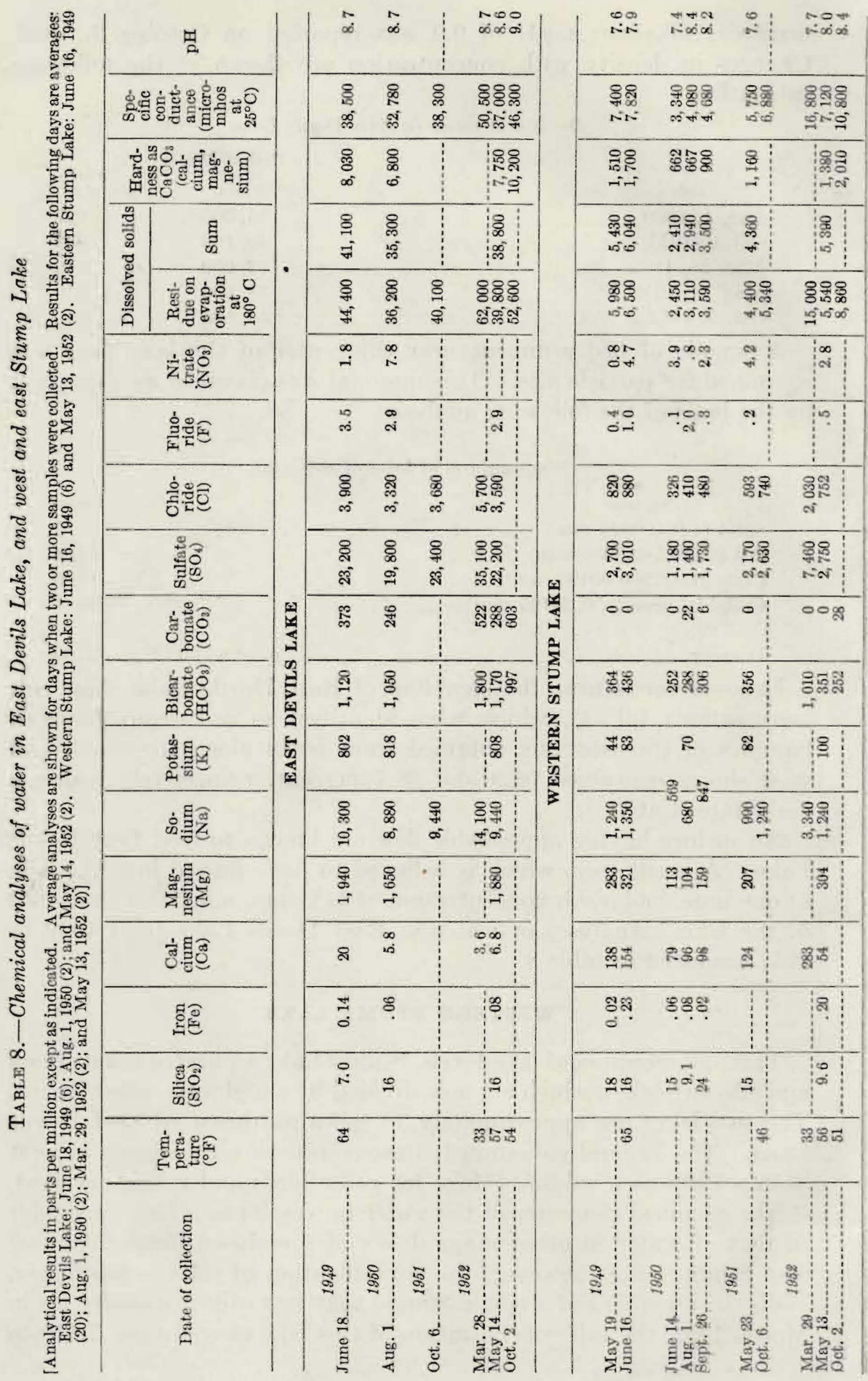




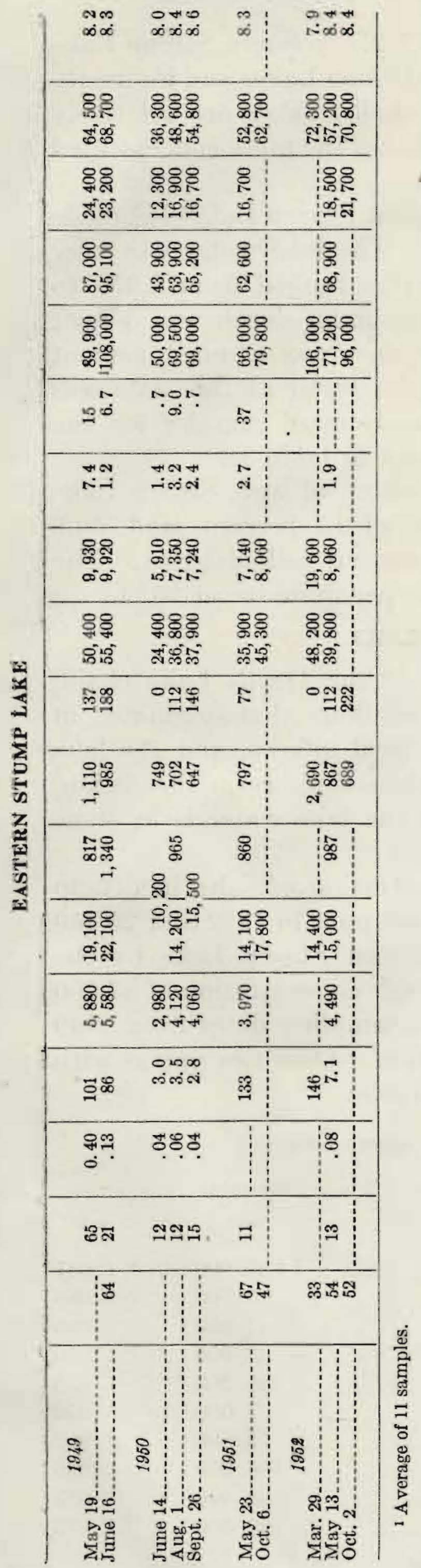


8,860 ppm during May 1949 to October 1952. Western Stump Lake receives considerable inflow from Swan and Coon Lakes and indirectly from Rose Lake to the north. These smaller lakes are relatively fresh (table 3), and overflow from them dilutes the more concentrated water of west Stump Lake.

On June 16, 1949, a detailed study of west Stump Lake was made to determine the character of the water. The lake water was very uniform in quality. (See fig. 15.) Samples ranged from 5,950 to $6,090 \mathrm{ppm}$ (140 ppm difference). The maximum depth was 3 feet, and the concentration of salts near the surface was about 1 percent less than near the bottom. Density of the water at this date was 1.001 grams per milliliter at $20^{\circ} \mathrm{C}$. Analyses of samples for the period May 1949 to October 1952 are listed in table 8 .

A sample of bed sediment from the bottom of west Stump Lake was classified as clayey silt and consisted of 2.7 percent sand, 50.5 percent silt, 12.3 percent clay, and 34.5 percent colloidal clay. The density of the bed deposit was 2.60 grams per milliliter at $20^{\circ} \mathrm{C}$.

\section{EASTERN STUMP LAKE}

Eastern Stump Lake is the end lake of the Devils Lake chain. As such, this lake at one time received all flows that originated in the upper basin. It now eatches small local inflows, and the lake water is the most brackish of major surface supplies in the region. Compared with sea water $(35,000 \mathrm{ppm})$ the lake water is at some periods 2 to 3 times as salty.

According to Young (1924) the concentration of salts in Stump Lake (before lake segmentation) was $19,000 \mathrm{ppm}$ in 1912 and 25,450 ppm in 1923. Analysis of the water in east Stump Lake by the Geological Survey in May 1949 showed a salt concentration of 87,000 $\mathrm{ppm}$. Concentrations in the water on 10 sampling dates from 1949 to 1952 ranged from 43,900 to $106,000 \mathrm{ppm}$. Densities varied with concentrations as shown in the following table:

\section{Density of water in east Stump Lake}

\begin{tabular}{|c|c|c|c|}
\hline & Date & $\begin{array}{l}\text { Concentra- } \\
\text { tion of } \\
\text { salts } \\
(\text { ppm })\end{array}$ & $\begin{array}{l}\text { Den- } \\
\text { sity } \\
\text { ofml } \\
\text { at } 20^{\circ} \\
\text { C) }\end{array}$ \\
\hline May 19,1949 & & 87,000 & 1. 087 \\
\hline June 16,1949 & 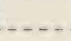 & 95,100 & 1. 088 \\
\hline June 14,1950 & & 43,900 & 1. 036 \\
\hline Aug. $1,1950 \ldots$ & & 63,900 & 1. 050 \\
\hline Sept. 26,1950 & & 65,200 & 1. 056 \\
\hline May 23,1951 & & 62,600 & 1. 052 \\
\hline Oct. $6,1951 \ldots$ & & 79,800 & 1. 067 \\
\hline Mar. 29, 1952 & & 106,000 & 1. 086 \\
\hline May 13,1952 & & 68,900 & 1. 057 \\
\hline Oct. 2,1952 & & 96,000 & 1. 083 \\
\hline
\end{tabular}




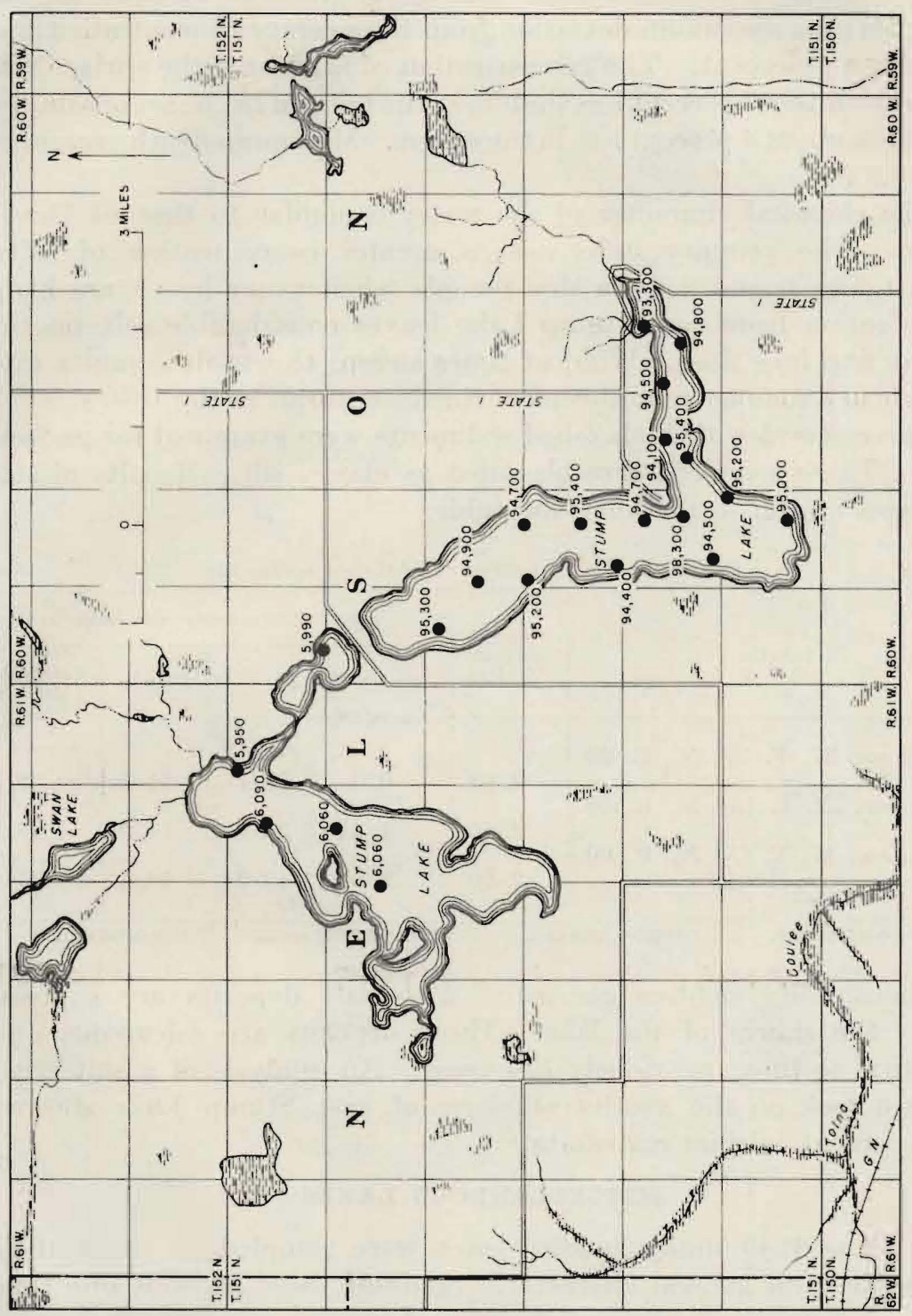

을 
A salinity survey of east Stump Lake was made on June 16, 1949, and samples were collected at 16 points in the lake for analysis; at some points both surface and bottom samples were obtained. Soundings and water temperatures were recorded. The concentration of salts in the lake water was fairly uniform in cross section (fig. 15); the maximum deviation from the average concentration was less than 4 percent. The concentration of salts near the surface was approximately 7 percent less than near the bottom in one set of samples but only about 4 percent less in the others. Maximum depth measured was 6.8 feet.

The chemical character of the water is similar to that of Devils Lake. The primary difference is greater concentration of salts. (See tables 6 and 8.) In dry periods when water losses are high, evaporation from east Stump Lake leaves considerable salt on the shores and lake floor. Wind at times sweeps these salt deposits into the air in a manner reminiscent of the dust storms of the 1930's.

Three samples of the lakebed sediments were examined for particle size. These sediments are classified as clayey silt. Results of size analyses appear in the following table:

Density and size analyses of lakebed sediments

\begin{tabular}{|c|c|c|c|c|c|}
\hline \multirow[b]{2}{*}{ Location } & \multirow{2}{*}{$\begin{array}{l}\text { Density } \\
(\mathrm{g} / \mathrm{ml} \text { at } \\
\left.20^{\circ} \mathrm{C}\right)\end{array}$} & \multicolumn{4}{|c|}{ Percent in indicated size range } \\
\hline & & Sand 1 & Silt ${ }^{2}$ & Clay $^{3}$ & $\begin{array}{l}\text { Colloidal } \\
\text { clay }\end{array}$ \\
\hline $\mathrm{NW}_{W^{1 / 4}}$ sec. 27, T. 151 N., R. 60 & 2. 68 & 0.6 & 58.7 & 11.5 & 29. 2 \\
\hline $\begin{array}{l}\text { NE1/4 sec. } 32, \text { T. } 151 \text { N., R. } 60 \\
W\end{array}$ & 2. 66 & 1.4 & 55,0 & 14.0 & 29.6 \\
\hline $\begin{array}{l}N_{W}^{1 / 4} \text { sec. } 17, \text { T. } 151 \text { N., R. } 60 \\
\text { W }\end{array}$ & 2. 66 & 2. 6 & 49. 2 & 14. 6 & 33. 6 \\
\hline
\end{tabular}

Rocks and boulders encrusted with salt deposits are exposed along the shores of the lake. These deposits are calcareous and identical to those previously discussed. An analysis of a salt crust from a rock on the southwest shore of east Stump Lake showed 99.3 percent calcium carbonate.

\section{MISCELLANEOUS LAKES}

In June 1949 many smaller lakes were sampled to study their properties and general character. Some of these lakes at one time were part of Devils Lake. Analytical results and sampling point locations are given in tables 3 and 4 .

Cranberry Lake and Wood Lake contain waters of distinetive properties and are described in the following paragraphs. 
Cranberry Lake.-Cranberry Lake is 40 miles west of the city of Devils Lake and a short distance north of Esmond. The water from this lake flows intermittently through a small coulee into the Sheyenne River; Cranberry Lake, however, lies in the same physiographic province as the lakes in Devils Lake basin and is, therefore, included in this report. The lake water has peculiar properties and differs markedly from waters in the Devils Lake complex. Cranberry Lake water is strongly alkaline; in 4 samples the $\mathrm{pH}$ ranged from 9.6 to 9.8 . This water is essentially a mixture of the carbonates, bicarbonates, and sulfates of sodium; unlike lake waters to the east, Cranberry Lake water is very soft. On the basis of the 4 samples that were collected from June 1949 to October 1952, the specific conductance ranged from 14,400 to 36,600 micromhos at $25^{\circ} \mathrm{C}$, hardness as $\mathrm{CaCO}_{3}$ ranged from 31 to $67 \mathrm{ppm}$, and density of the water ranged from 1.008 to 1.030 grams per milliliter at $20^{\circ} \mathrm{C}$. Analyses of samples are reported in table 9.

TABLE 9.-Chemical analyses of water in Cranberry Lake [Analytical results in parts per million except as indicated]

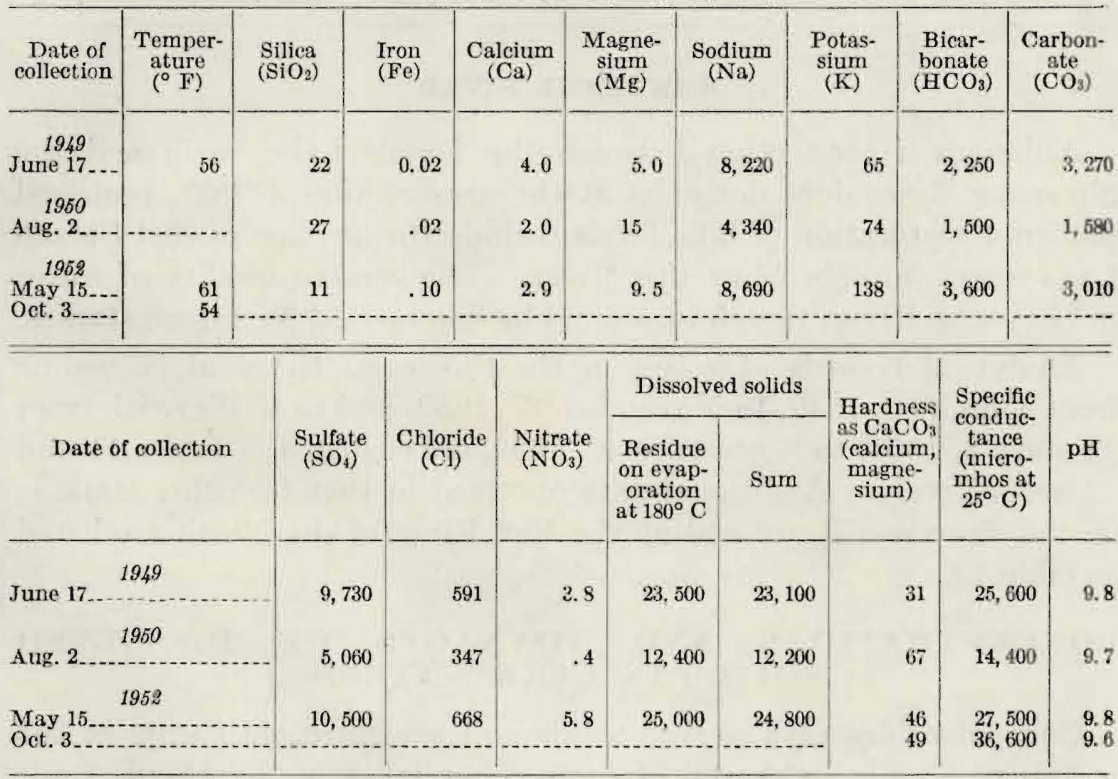

Wood Lake.-Wood Lake, a popular fishing resort about 15 miles south of the city of Devils Lake, is a fresh-water lake. The water is moderately alkaline and a bicarbonate type. Samples collected from May 1949 to October 1952 were low in mineral content. The range in concentration of dissolved solids of 4 samples was 362 to $407 \mathrm{ppm}$, and the range in hardness was 268 to $294 \mathrm{ppm}$. Analyses of samples are listed in table 10 . 
TABLE 10.-Chemical analyses of water in Wood Lake

[Analytical results in parts per million except as indicated]

\begin{tabular}{|c|c|c|c|c|c|c|c|c|c|c|}
\hline $\begin{array}{l}\text { Date of } \\
\text { collection }\end{array}$ & $\begin{array}{c}\text { Temper- } \\
\text { ature } \\
\left(\begin{array}{l}\circ \\
\text { F })\end{array}\right.\end{array}$ & $\begin{array}{l}\text { Silica } \\
\left(\mathrm{SiO}_{2}\right)\end{array}$ & $\begin{array}{l}\text { Iron } \\
(\mathrm{Fe})\end{array}$ & $\underset{(\mathrm{Ca})}{\text { Calcium }}$ & $\begin{array}{l}\text { Magne- } \\
\text { sium } \\
(\mathrm{Mg})\end{array}$ & $\begin{array}{l}\text { Sodium } \\
(\mathrm{Na})\end{array}$ & $\begin{array}{l}\text { Potas- } \\
\text { sium } \\
(\mathrm{K})\end{array}$ & $\begin{array}{c}\text { Bicar- } \\
\text { bonate } \\
\left(\mathrm{HCO}_{8}\right)\end{array}$ & \multicolumn{2}{|c|}{$\begin{array}{c}\text { Carbon- } \\
\text { ate } \\
\left(\mathrm{CO}_{3}\right)\end{array}$} \\
\hline $\begin{array}{c}1949 \\
\text { May 19 } \\
\text { June } 16 . .\end{array}$ & 71 & $\begin{array}{l}12 \\
13\end{array}$ & $\begin{array}{r}0.02 \\
.08\end{array}$ & $\begin{array}{l}29 \\
27\end{array}$ & $\begin{array}{l}52 \\
55\end{array}$ & $\begin{array}{l}25 \\
27\end{array}$ & $\begin{array}{l}13 \\
9.6\end{array}$ & $\begin{array}{l}297 \\
316\end{array}$ & & $\begin{array}{r}20 \\
8\end{array}$ \\
\hline $\begin{array}{c}1952 \\
\text { May } 15 \\
\text { Oct. } 3\end{array}$ & 52 & 13 & .04 & 28 & 48 & 23 & 15 & $\begin{array}{l}308 \\
336\end{array}$ & & $\begin{array}{r}10 \\
0\end{array}$ \\
\hline \multirow[b]{2}{*}{$\begin{array}{l}\text { Date of } \\
\text { collection }\end{array}$} & \multirow[b]{2}{*}{$\begin{array}{l}\text { Sulfate } \\
\left(\mathrm{SO}_{4}\right)\end{array}$} & \multirow[b]{2}{*}{$\begin{array}{l}\text { Chloride } \\
\text { (Cl) }\end{array}$} & \multirow[b]{2}{*}{$\underset{(\mathrm{F})}{\text { Fluoride }}$} & \multirow[b]{2}{*}{$\begin{array}{l}\text { Nitrate } \\
\left(\mathrm{NO}_{3}\right)\end{array}$} & \multicolumn{2}{|c|}{ Dissolved solids } & \multirow{2}{*}{$\begin{array}{l}\text { Hardness } \\
\text { as CaCO } \\
\text { (calcium, } \\
\text { magne- } \\
\text { sium) }\end{array}$} & \multirow{2}{*}{\multicolumn{2}{|c|}{\begin{tabular}{|c} 
Specific \\
conduct- \\
ance \\
(micro- \\
mhos at \\
$25^{\circ} \mathrm{C}$ )
\end{tabular}}} & \multirow[b]{2}{*}{$\mathrm{pH}$} \\
\hline & & & & & $\begin{array}{l}\text { Residue } \\
\text { on evap- } \\
\text { oration } \\
\text { at } 180^{\circ} \mathrm{C}\end{array}$ & Sum & & & & \\
\hline $\begin{array}{c}1949 \\
\text { May } 19 \\
\text { June } 16 .\end{array}$ & $\begin{array}{l}70 \\
72\end{array}$ & $\begin{array}{l}6.0 \\
7.5\end{array}$ & $\begin{array}{r}0.3 \\
.2\end{array}$ & $\begin{array}{l}0.2 \\
1.5\end{array}$ & $\begin{array}{l}407 \\
384\end{array}$ & $\begin{array}{l}377 \\
379\end{array}$ & $\begin{array}{l}286 \\
294\end{array}$ & & $\begin{array}{l}719 \\
647\end{array}$ & $\begin{array}{l}8.6 \\
8.2\end{array}$ \\
\hline $\begin{array}{l}1952 \\
\text { May } 15 \\
\text { Oct. } 3\end{array}$ & 54 & 6. 5 & .2 & 1.6 & $\begin{array}{l}376 \\
362\end{array}$ & 351 & $\begin{array}{l}268 \\
274\end{array}$ & & $\begin{array}{l}629 \\
610\end{array}$ & $\begin{array}{l}8.4 \\
8.1\end{array}$ \\
\hline
\end{tabular}

\section{SHEYENNE RIVER}

Although a connection between the Devils Lake basin and the Sheyenne River does not exist at the present time (1953), proposed plans for restoration of lake levels include the outflow of east Stump Lake water into the Sheyenne River. The present quality of water in Sheyenne River, therefore, should be determined for future studies.

Analytical records of water in the Sheyenne River at Sheyenne from March 30, 1949, to November 17, 1950, and near Warwick from January 8, 1951, to September 30, 1952, are reported in tables 11 and 12 , respectively. Additional data obtained in 1949 for other stations on the Sheyenne River and on the Red River of the North are listed in table 13.

\section{CONCENTRATIONS AND TONNAGES OF DISSOLVED SOLIDS IN LAKE WATERS}

Concentrations of dissolved solids and several constituents in the waters of Devils Lake and of some other lakes in the Devils Lake basin have been determined occasionally beginning in 1899 . These concentrations of dissolved solids together with known volumes of water in the lakes have been used to compute the tonnages of dissolved solids. The volumes of water and the tonnages of dissolved solids are discussed by individual lakes. Estimates are given for the possible concentrations of dissolved solids if the lakes are filled to a higher level by diverting water into them. 
TABLE 11.-Chemical analyses of water in the Sheyenne River at Sheyenne

[Analytical results in parts per million except as indicatod]

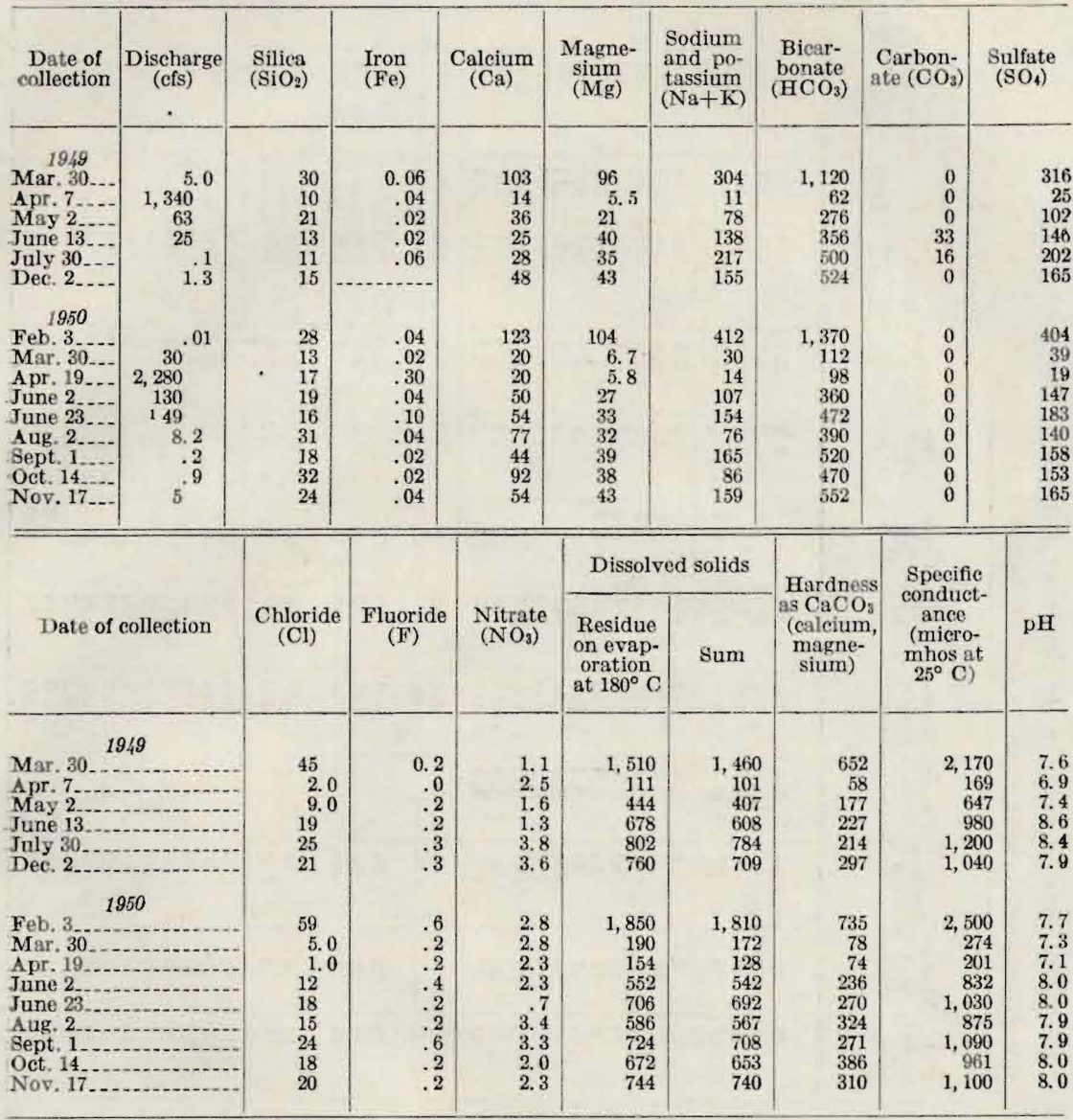

${ }^{3}$ Mean daily discharge.

Tonnages of dissolved solids, as computed for this report were usually based on concentrations of only 1 or 2 samples for any one time. However, during June 1949 many samples were collected from some lakes. These samples show slight lateral variations in Devils, East Devils, and Stump Lakes. (See figs. 12, 14, and 15.) Although one sample is usually fairly representative of the concentration in the entire lake, one sample alone will not always give a wholly dependable average concentration for the lake. Also, some samples were not completely analyzed, and for these samples the figure for dissolved solids is residue on evaporation at $180^{\circ} \mathrm{C}$. The figure for dissolved solids for other samples is the sum of the determined constituents. 


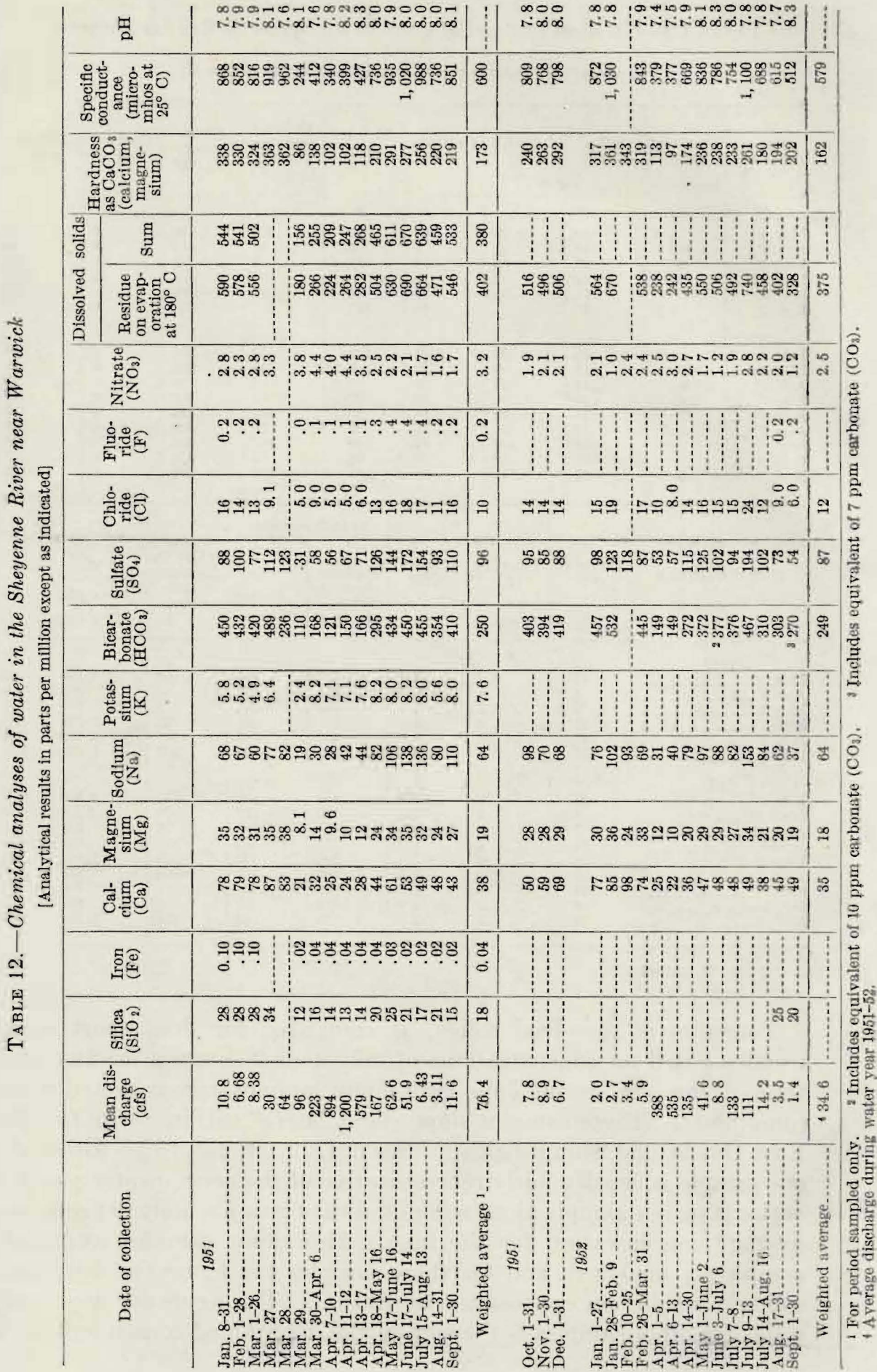


DISSOLVED SOLIDS IN LAKE WATERS

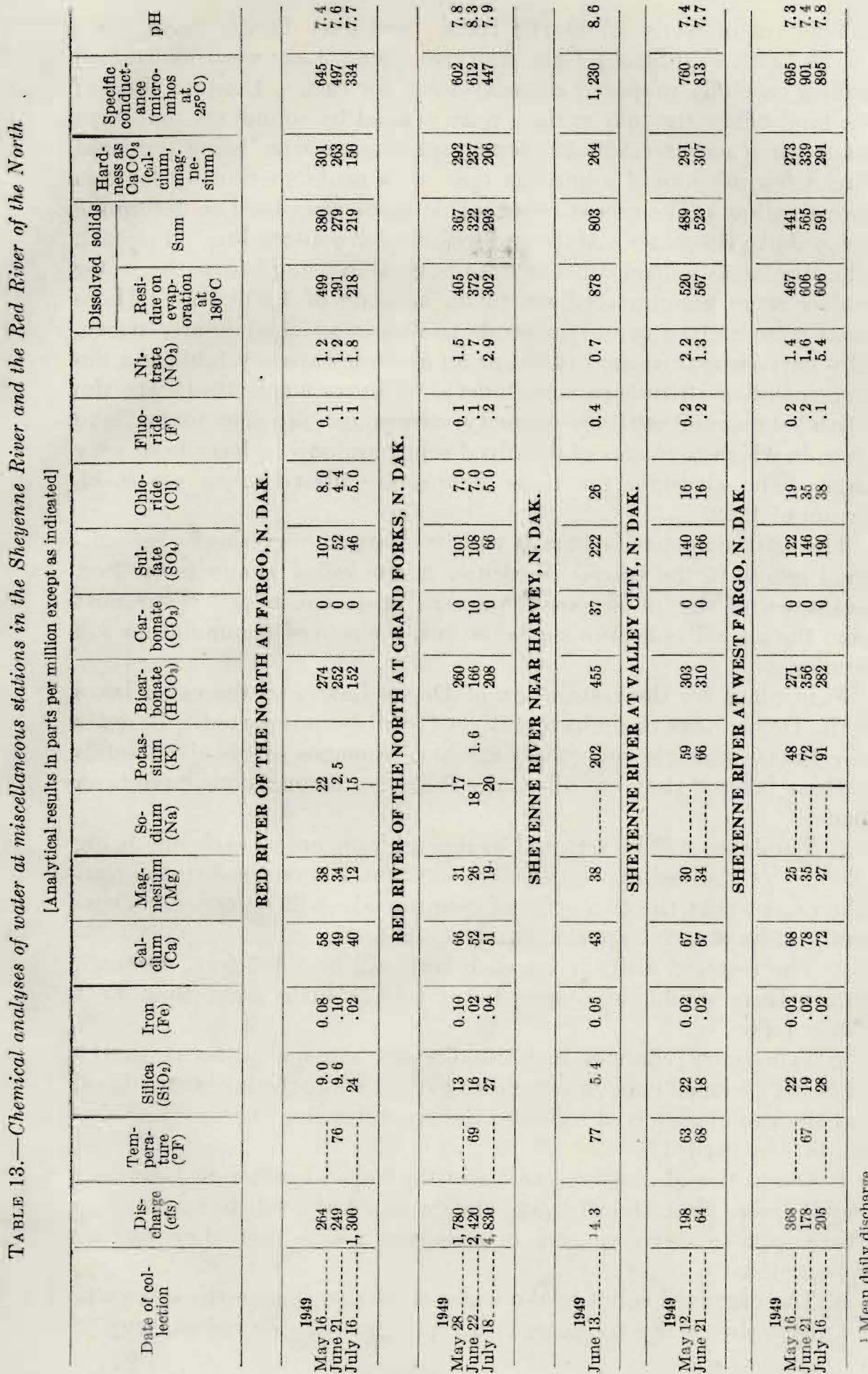


Volumes of water in Devils Lake, East Bay Devils Lake, East Devils Lake, west Stump Lake, and east Stump Lake were determined from a carefully prepared capacity table for each. Contour lines of the land below the lake surface were defined by soundings that were made when recent (1950-52) topographic maps were being prepared plus a few additional soundings that were made specifically for this investigation. The recent topographic maps were used to determine areas above the water surface and within each contour line. For each lake, the areas within contour lines both above and below the water surface were planimetered up to an altitude of 1,430 feet. These areas were plotted against altitude to obtain an altitude-area curve. This curve was then used to define an altitude-capacity table and the corresponding altitude-capacity curve. Figures 9 and 16-19 are the altitude-area and altitude-capacity curves for the five major lake areas in which tonnages of dissolved solids are now or have been very large. The altitudes for these figures are above mean sea level, datum of 1929 .

The altitude-capacity curves will be changed very slowly by sediment inflow to the lakes. Velocities in the inflow channels are low, and much of the inflow passes through upstream lakes. Some dust from the air will collect in the lakes, but the rate of accumulation will be slow.

Firm plans for the restoration of Devils Lake and the other lakes of the Devils Lake chain have not yet (1953) been reported. In order to estimate possible concentrations and tonnages of dissolved solids in these lakes if they are filled, the following assumptions have been made:

1. The lakes will be restored in downstream order, each one being filled to its planned capacity before any water is released to the next lake except that the two arms of Stump Lake will be raised concurrently at least above approximately 1,404 feet.

2. The restored altitude for each lake will be 1,425 feet, although Stump Lake would, of course, be at least a little lower than East Devils Lake.

3. Temporary changes in ground-water storage adjacent to the lakes will be small enough to be disregarded while the lakes are filling, and the loss of dissolved solids to the ground water during filling also can be disregarded.

4. Quantities of dissolved solids in the natural inflow to East Bay Devils Lake, East Devils Lake, and Stump Lake will be so small in comparison to other sources of dissolved solids that they can be disregarded.

5. The dissolved solids in the water to be diverted to the lakes will not react chemically to cause either precipitation or redissolving of 


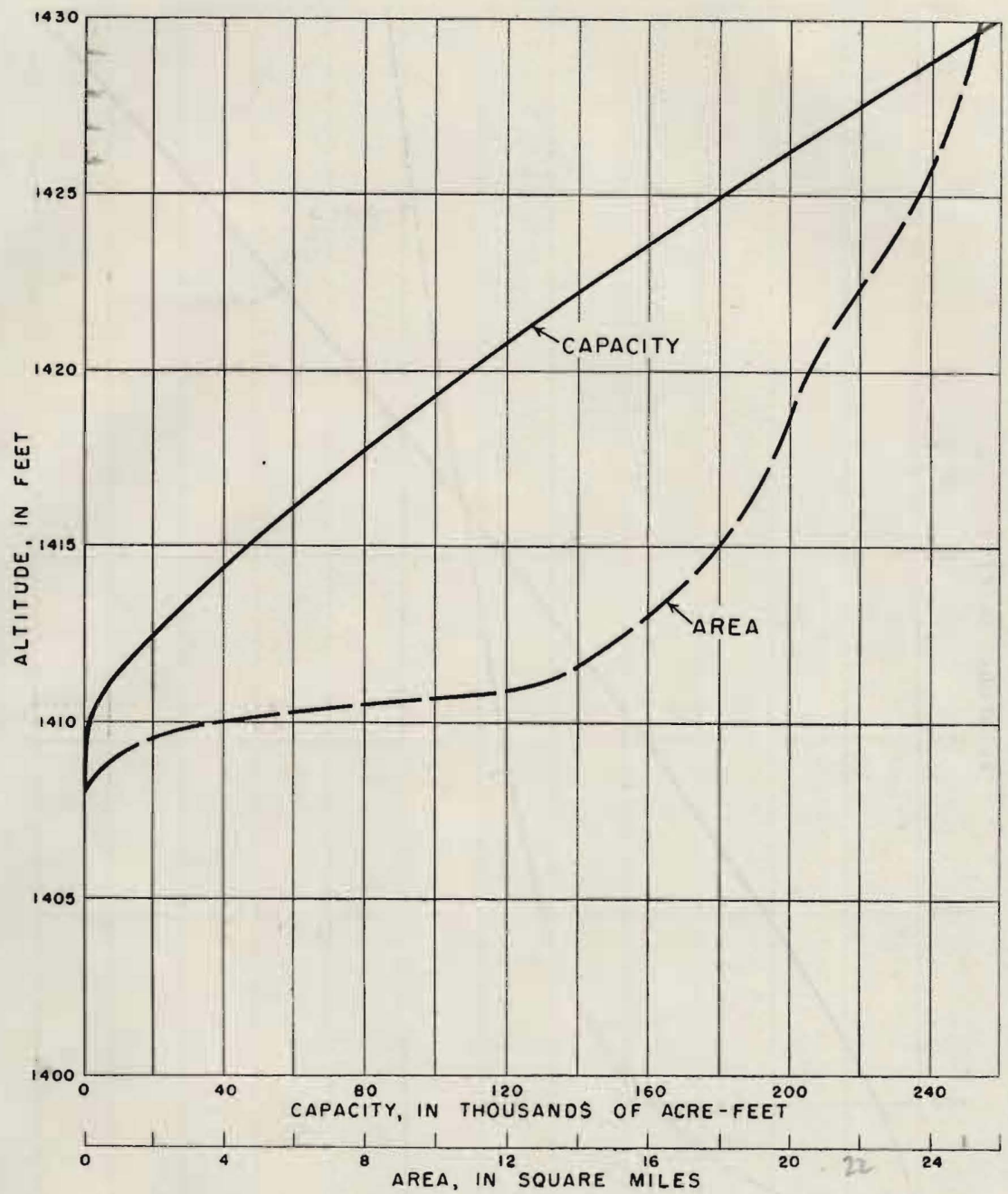

FigURe 16.-Area and capacity curves for East Bay Ier ils Lake.

salts at appreciably different rates than have occurred in the past in the waters of Devils Lake.

6. 'The dissolved solids in each lake will be distributed nearly uniformly. In particular the lakes will not be stratified to any appreciable extent.

7. Net evaporation, the difference between total evaporation and precipitation, from the lake surface will average about 670 acre-feet per square mile per year.

8. Inflow to the lakes will average about 12.3 acre-feet annually per square mile of drainage area. 


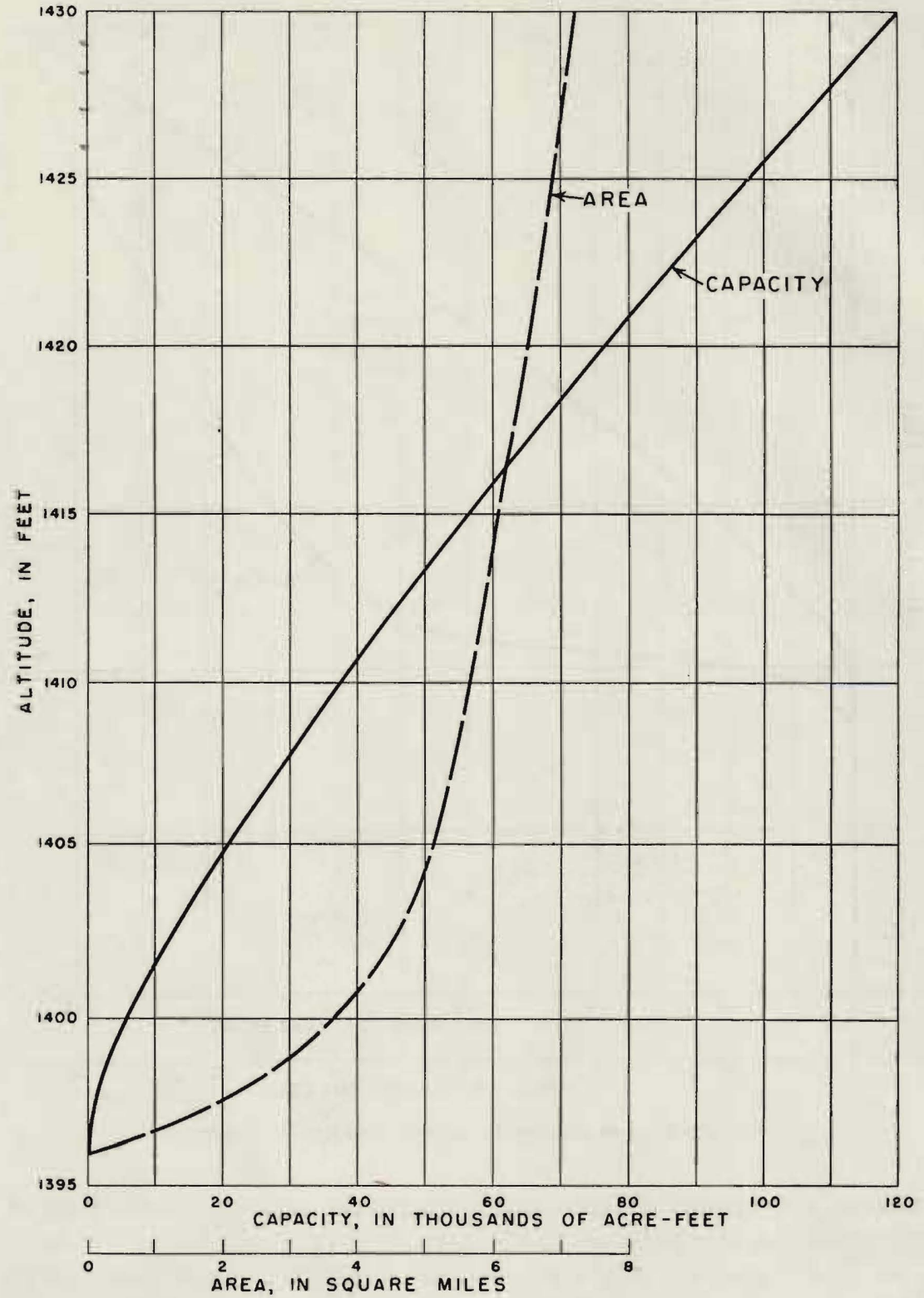

Figure 17.-Area and capacity curves for East Devils Lake.

9. Both rate of diversion and concentration of dissolved solids in the diverted water will be treated as though they are constant. Actually the diversion might be made during only part of the year. Probably the effect of variations in the concentration and in the rate of diversion into Devils Lake would not change the computed esti- 


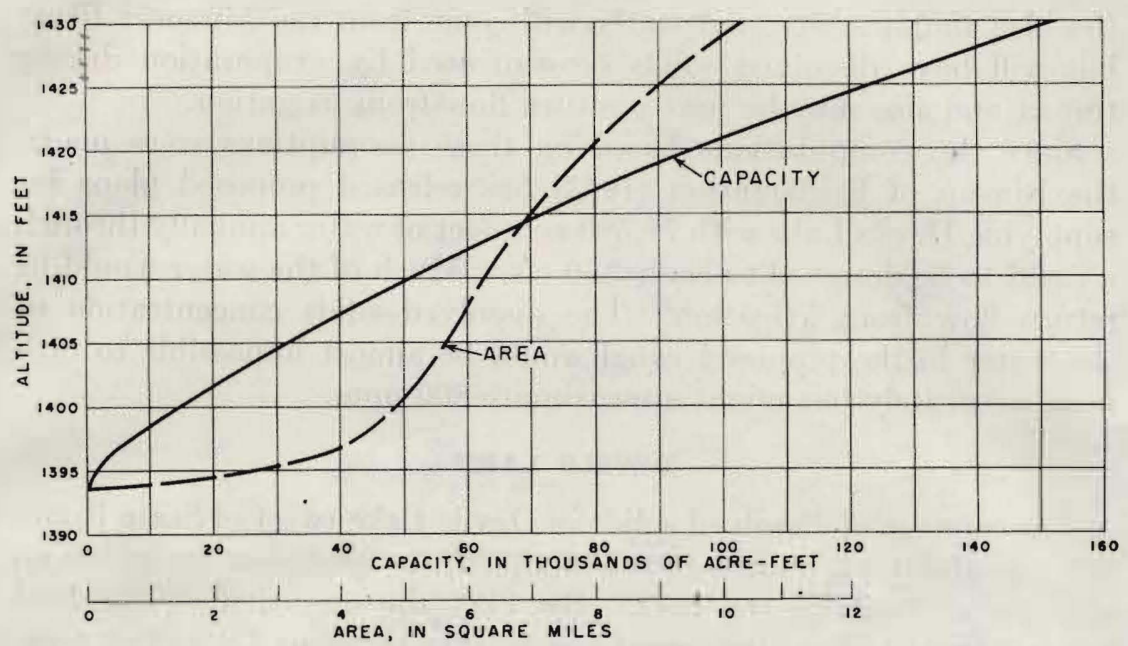

Figure 18.-Area and capacity curves for west Stump Lake.

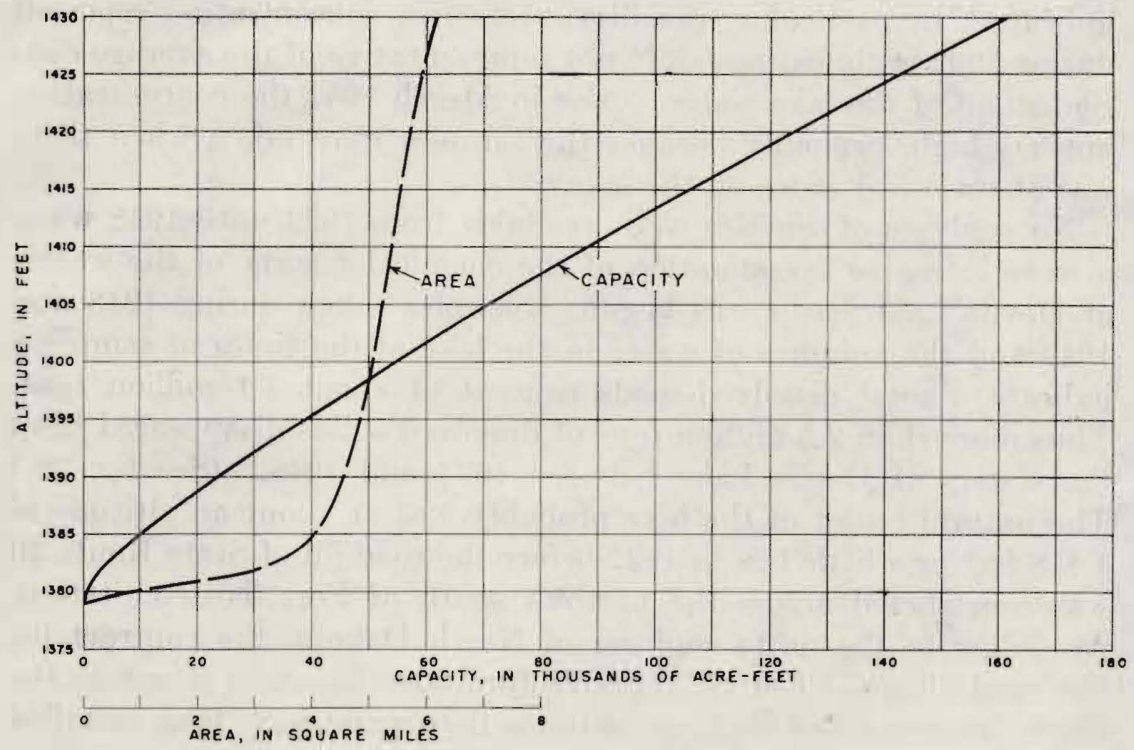

FIGURE 19.-Area and capacity curves for east Stump Lake.

mates materially. Computations are made for a diversion into Devils Lake of (A) 180,000 acre-feet per year, which is equivalent to $250 \mathrm{cfs}$ throughout the year or $500 \mathrm{cfs}$ for 6 months, and a concentration of $800 \mathrm{ppm}$ of dissolved solids; (B) 180,000 acre-feet per year and a concentration of $500 \mathrm{ppm}$; and (C) 90,000 acre-feet per year and a concentration of $800 \mathrm{ppm}$. The assumption of $800 \mathrm{ppm}$ is made with

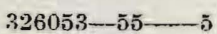


the idea that the diverted water will come from the Missouri River but will have dissolved solids concentrated by evaporation during transit and also may be partly return flow from irrigation.

Since the computations based on these assumptions were made, the Bureau of Reclamation (1953) has released proposed plans for supplying Devils Lake with 77,500 acre-feet of water annually through a canal to be designed to carry $370 \mathrm{cfs}$. Much of the water would be return flow from irrigation. The dissolved-solids concentration of the water in the proposed canal would be almost impossible to estimate accurately but might approximate $800 \mathrm{ppm}$.

\section{DEVILS LAKE}

The tonnage of dissolved solids in Devils Lake (west of State Route 20) was about 4.2 million tons from 1899 , the first year for which an analysis is available, to 1914 . By 1923 the quantity of dissolved solids seemed to have decreased appreciably to about 3.8 million tons. (See table 14 and fig. 20.) Probably the actual tonnages did not vary as much between consecutive sampling times as the samples seem to indicate. In particular, the dissolved-solids concentration reported during 1902 is almost certainly not representative of the average concentration of the lake water. Also in March 1952 the concentration appears high, probably because the samples were taken when there was about 3 feet of ice on the lake.

No analyses of samples were available from 1923 until 1948 when a more intensive investigation of the chemical quality of the waters of Devils Lake basin was begun. Samples taken during 1948 and 1949 and the volumes of water in the lake at the times of sampling indicate a total dissolved-solids content of about 1.1 million tons. Thus more than 2.5 million tons of dissolved solids disappeared from the waters of Devils Lake between 1923 and 1948. (See fig. 20.) The natural outlet of the lake probably was at about an altitude of 1,418 feet or a little less in 1922 before the road fill of State Route 20 was constructed across the narrows south of Fort Totten Station. According to the State engineer of North Dakota, the contract for this road fill was let in 1922. No information has been found on the size or bottom altitude of any eulverts that might have been installed when the fill was first constructed. In May 1952 no culverts were found in the fill. Although some of the 2.5 million tons of dissolved solids may have been discharged into East Bay Devils Lake during and after 1923, probably almost all this tonnage was precipitated from the lake water in the area west of State Route 20. The question immediately arises as to whether this large quantity of salts will be redissolved if the lake is restored to or above 1,416 feet, the altitude in 1923 . 
TABLE 14.-Approximate volumes of water and tonnages of dissolved solids in Devils Lake, N. Dak., 1899-1952

[A, Young (1924); B, Babcock (1903); C, Pope (1909, p. 14-15); D, Daudt (1911); E, Nerhus, P. T., (1920, A study of solubility relations of the salts in Devils Lake water: Thesis for Master or Sci. Degree, $N$. Dak. Univ., p. 4); F, U. S. Geol. Survey, 1952]

\begin{tabular}{|c|c|c|c|c|c|c|}
\hline \multirow{2}{*}{$\begin{array}{l}\text { Num- } \\
\text { ber } \\
\text { of } \\
\text { samples }\end{array}$} & \multirow[b]{2}{*}{ Date } & \multirow{2}{*}{$\begin{array}{l}\text { Lake } \\
\text { altitude } \\
\text { in feet } \\
\text { (datum of } \\
\text { 1929) }\end{array}$} & \multirow{2}{*}{$\begin{array}{l}\text { Volume } \\
\text { of water } \\
\text { (acre-feet) }\end{array}$} & \multicolumn{2}{|c|}{ Dissolved solids } & \multirow{2}{*}{$\begin{array}{l}\text { Souree } \\
\text { of con- } \\
\text { centra- } \\
\text { tions }\end{array}$} \\
\hline & & & & $\begin{array}{c}\text { Concen- } \\
\text { trution } \\
(\mathrm{ppm})\end{array}$ & $\begin{array}{l}\text { Quantity } \\
\text { (tons) } \mathrm{t}\end{array}$ & \\
\hline & $\begin{array}{l}1899 \\
1902 \\
1906 \\
1907 \\
1911\end{array}$ & $\begin{array}{l}21,424.6 \\
21,425.2 \\
21,423.9 \\
21,423.6 \\
21,420.3\end{array}$ & $\begin{array}{l}374,000 \\
392,000 \\
353,000 \\
345,000 \\
262,000\end{array}$ & $\begin{array}{r}38,471 \\
10,874 \\
48,517 \\
49,448 \\
311,278\end{array}$ & $\begin{array}{l}4,310,000 \\
5,800,000 \\
4,090,000 \\
4,430,000 \\
4,020,000\end{array}$ & $\begin{array}{l}\mathrm{A} \\
\mathrm{B} \\
\mathrm{C} \\
\mathrm{C} \\
\mathrm{D}\end{array}$ \\
\hline & $\begin{array}{l}1914 \\
1918 \\
1919 \\
1920 \\
1923\end{array}$ & $\begin{array}{l}21,420.1 \\
21,416.9 \\
21,418.0 \\
21,416.9 \\
21,416.3\end{array}$ & $\begin{array}{l}257,000 \\
193,000 \\
214,000 \\
193,000 \\
182,000\end{array}$ & $\begin{array}{ll}3 & 12,092 \\
3 & 14,452 \\
3 & 13,462 \\
3 & 15,889 \\
3 & 15,210\end{array}$ & $\begin{array}{l}4,230,000 \\
3,790,000 \\
3,920,000 \\
4,170,000 \\
3,760,000\end{array}$ & $\begin{array}{l}\mathrm{E} \\
\mathrm{E} \\
\mathrm{A} \\
\mathrm{E} \\
\mathrm{A}\end{array}$ \\
\hline & $\begin{array}{l}\text { Nov. } 20,1948 \\
\text { May } 19,1949 \\
\text { June } 14,18,1949 \\
\text { May } 3,1950 \ldots \\
\text { May } 24,1950\end{array}$ & $\begin{array}{l}1,404.2 \\
1,405.7 \\
1,406.6\end{array}$ & $\begin{array}{r}37,000 \\
51,000 \\
59,700 \\
110,000\end{array}$ & $\begin{array}{r}25,000 \\
17,300 \\
13,400 \\
6,130 \\
38,140\end{array}$ & $\begin{array}{l}1,260,000 \\
1,200,000 \\
1,090,000 \\
1,220,000\end{array}$ & $\begin{array}{l}\mathrm{F} \\
\mathrm{F} \\
\mathrm{F} \\
\mathrm{F} \\
\mathrm{F}\end{array}$ \\
\hline & $\begin{array}{l}\text { June } 8,1950 \\
\text { June } 13,1950 . \\
\text { June } 15,1950 \\
\text { June } 22,1950 . \\
\text { July } 7,1950 \ldots\end{array}$ & $\begin{array}{l}1,411.2 \\
51,413.1 \\
51,413.3 \\
{ }^{5} 1,413.4 \\
1,413.75 \\
1,414.28\end{array}$ & $\begin{array}{l}110,000 \\
133,000 \\
136,000 \\
137,000 \\
142,000 \\
150,000\end{array}$ & $\begin{array}{r}3,140 \\
3,620 \\
6,870 \\
6,880 \\
7,080 \\
6,760\end{array}$ & $\begin{array}{l}1,220,000 \\
1,380,000 \\
1,270,000 \\
1,280,000 \\
1,370,000 \\
1,380,000\end{array}$ & $\begin{array}{l}F \\
F \\
F \\
F \\
F \\
F\end{array}$ \\
\hline & $\begin{array}{l}\text { Aug. 1, } 1950 \\
\text { Aug. } 2,1950 \ldots \\
\text { Sept. 1, } 1950 \ldots \\
\text { Sept. } 27,1950 \\
\text { Nov. } 17,1950 \\
\end{array}$ & $\begin{array}{l}1,414.59 \\
1,414.63 \\
1,414.85 \\
1,414.80 \\
1,414.82\end{array}$ & $\begin{array}{l}155,000 \\
155,000 \\
158,000 \\
158,000 \\
158,000\end{array}$ & $\begin{array}{l}6,560 \\
6,620 \\
6,620 \\
6,340 \\
6,580\end{array}$ & $\begin{array}{l}1,380,000 \\
1,400,000 \\
1,420,000 \\
1,360,000 \\
1,410,000\end{array}$ & $\begin{array}{l}\mathrm{F} \\
\mathrm{F} \\
\mathrm{F} \\
\mathrm{F} \\
\mathrm{F}\end{array}$ \\
\hline $\begin{array}{l}1 \ldots . \\
1 \ldots \\
1 \ldots \\
2 \ldots \\
2 \ldots \\
1 \ldots\end{array}$ & $\begin{array}{l}\text { Dec. } 9,1950 \ldots \\
\text { May } 22,1951 \ldots \\
\text { Oct. } 6,1951 \\
\text { Mar. } 28,1952 \\
\text { May } 15,1952 \\
\text { Oct. } 2,1952 \ldots\end{array}$ & $\begin{array}{l}1,414.88 \\
1,415.34 \\
1,414.46 \\
1,414.36 \\
1,414.27 \\
1,412.88\end{array}$ & $\begin{array}{l}159,000 \\
166,000 \\
153,000 \\
150,000 \\
130,000\end{array}$ & $\begin{array}{r}6,990 \\
6,680 \\
37,300 \\
39,060 \\
7,300 \\
38,680\end{array}$ & $\begin{array}{l}1,510,000 \\
1,510,000 \\
1,520,000 \\
1,490,000 \\
1,530,000\end{array}$ & $\begin{array}{l}F \\
F \\
F \\
F \\
F \\
F\end{array}$ \\
\hline
\end{tabular}

1 Based on 62.5 pounds per cubic foot of lake water; weight varies somewhat with concentration of dissolved solids.

2 Average gage height during year.

${ }^{3}$ Residue on evaporation

4 Total constituents in solution.

${ }^{5}$ Interpolated gage height.

Since 1949 the total tonnage of dissolved solids in Devils Lake has increased considerably. By the end of 1950, the lake contained about 1.5 million tons of dissolved solids, and this tonnage has not changed appreciably from then to the fall of 1952 . During 1950, 1951 , and 1952 , the total inflow to Devils Lake was about 125,000 acre-feet according to the approximate computations of table 2 . On the basis of 9 samples that were collected from May to November 1950 from Mauvais Coulee, the concentration of dissolved solids in the water that flowed into Devils Lake was assumed to be $300 \mathrm{ppm}$. This concentration in 125,000 acre-feet of water represents about 50,000 tons of dissolved solids. Hence about $350,000(1,500,000$ $-1,100,000-50,000)$ tons of dissolved solids was added to the lake 


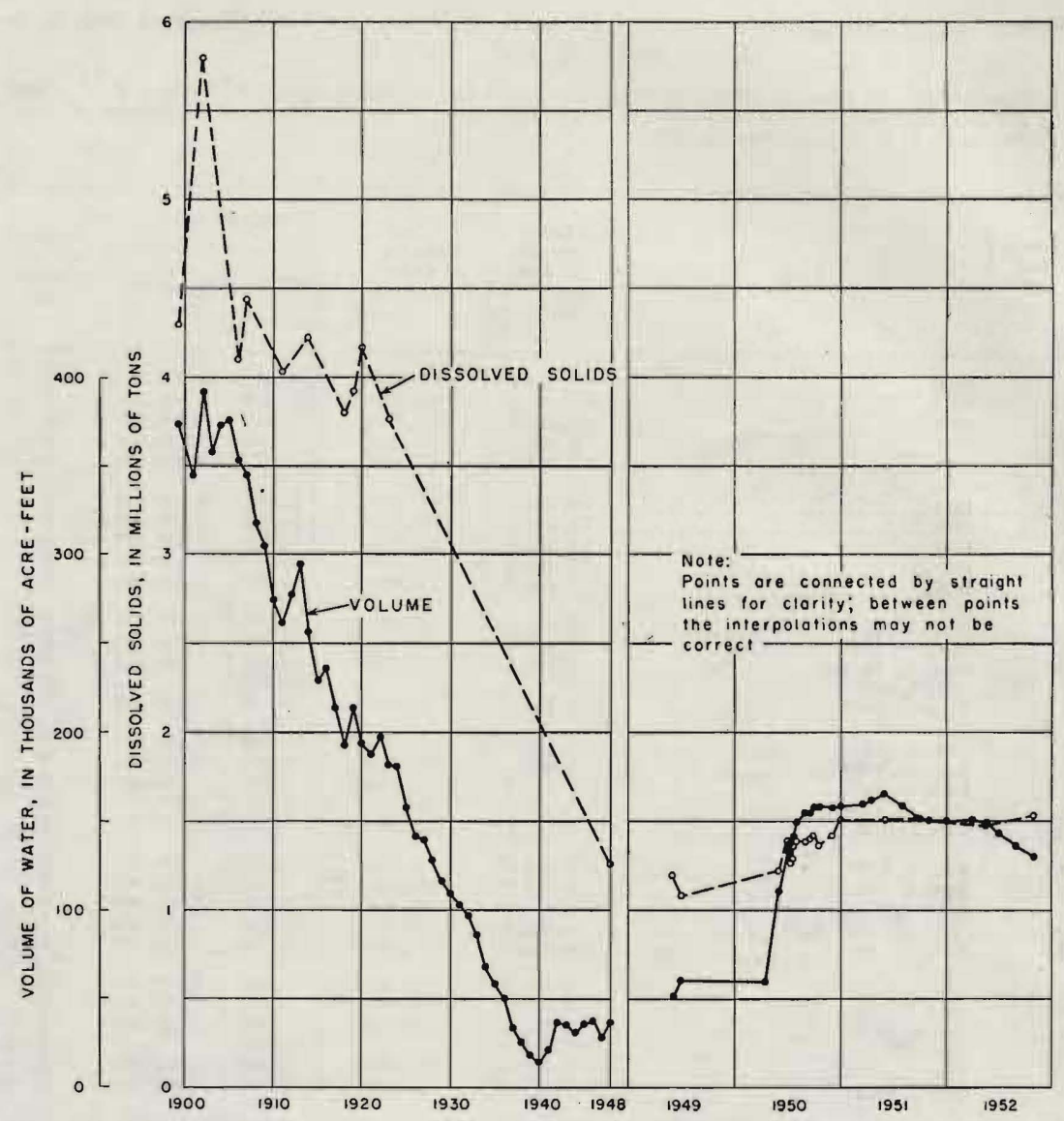

Frgure 20.- Volume of water and tonnage of dissolved solids in Devils Lake.

water during the 1950,1951 , and 1952 water years by the excess of redissolved salts over precipitated salts. However, according to these computations, more than 2 million tons of dissolved solids that was in the lake in 1923 was not in the lake water at the end of 1952. Some redissolving of salts might be obscured by the temporary loss of dissolved solids to ground-water storage while the lake was rising, but the computed tonnage of dissolved solids has not increased appreciably since the end of 1950 although the lake level has fallen more than 2 feet.

Assume that 180,000 acre-feet of water that has a concentration of $800 \mathrm{ppm}$ is diverted annually to Devils Lake. The natural inflow averages about 12,000 acre-feet annually and has a concentration of about $300 \mathrm{ppm}$. Then in round numbers the total annual inflow of water would be 190,000 acre-feet at an average concentration of 
$780 \mathrm{ppm}$. The annual inflow of dissolved solids would be 200,000 tons. The difference in capacity of Devils Lake between an altitude of 1,425 feet and 1,413 feet, the altitude at which filling is assumed to start, is approximately 385,000 minus 130,000 or 255,000 acre-feet. If Devils Lake is filled to 1,425 feet in 1.5 years, the net evaporation (evaporation minus precipitation on the lake) during filling would be about 38,000 acre-feet. The total volume of water required for filling would be 293,000 acre-feet, which would equal an inflow of 190,000 acre-feet per year for 1.5 years. The probable tonnage of dissolved solids in the lake immediately after filling would be the sum of the 1.5 million tons now in the lake, plus the inflow of 200,000 tons per year for 1.5 years, plus the quantity of salts that redissolved while the lake rose from 1,413 feet to 1,425 feet. The range in probable quantity redissolved is estimated to be 200,000 to 500,000 tons. Thus, the total quantity of dissolved solids in the lake when it was first filled would be about 2.0 million to 2.3 million tons, and the corresponding concentrations in 385,000 acre-feet of water would be about 3,800 to $4,400 \mathrm{ppm}$.

If Devils Lake were maintained at an altitude of 1,425 feet, the average annual net evaporation from its area of 47 square miles of surface would be about 670 acre-feet multiplied by 47 or 32,000 acre-feet. In round figures, the annual outflow from Devils Lake would be 30,000 acre-feet less than the annual inflow. For an assumed annual inflow of 190,000 acre-feet of water and 200,000 tons of dissolved solids, the annual outflow would be 160,000 acre-feet of water and would eventually be 200,000 tons of dissolved solids. Obviously when the concentration in Devils Lake finally becomes as diluted as the inflowing water can make it, the same amount of dissolved solids would, on the average, leave the lake as enters it. As the concentration in the lake and in the outflow at that time must equal approximately 200,000 tons in 160,000 acre-feet, the concentration in both lake (no stratification is assumed) and outflow will be about $920 \mathrm{ppm}$. The quantity of dissolved solids in the lake would, therefore, become stabilized at about 480,000 tons and a concentration of $920 \mathrm{ppm}$. These estimates and computations are summarized in table 15. The approximate continuous decrease in concentration of dissolved solids in Devils Lake has been computed and is shown in figure 21 by years for both the estimated probable maximum and the estimated probable minimum concentrations immediately after filling to 1,425 feet.

Two other assumptions of inflow to Devils Lake by diversions were also made. One was that the amount of annual diversion to Devils Lake would be 180,000 acre-feet, the same as in the preceding assumed rate of diversion, and that the concentration would be 500 
ppm. The other was that the annual diversion to Devils Lake would be 90,000 acre-feet and that the concentration would be $800 \mathrm{ppm}$. Results of computations that were based on these two assumptions are also given in table 15 . Computed changes in concentration with time are shown in figure 21 for probable maximum and minimum initial concentrations and for both these assumed rates and concentrations in the diverted water.

Table 15 and figure 21 summarize the computed results for three combinations of assumed rates of diversion to Devils Lake and of concentration of dissolved solids in the diverted water. Both the table and the figure show that the probable concentration immediately after Devils Lake is filled would be about the same for the different assumed concentrations and rates of inflow. The final or equilibrium concentrations for the lake do differ considerably under the three assumptions. Of course the concentration in the lake decreased faster for the lower assumed concentration in the inflow. It decreased much slower for the annual assumed diversion rate of 90,000 acre-feet than for the assumed rate of 180,000 acre-feet.

TABLE 15.-Summary of computations for Devils Lake and adjoining lakes of annual local inflow, net evaporation, dissolved solids, and water and years required to fill to an altitude of 1,425 feet

\begin{tabular}{|c|c|c|c|c|c|c|c|}
\hline \multirow{2}{*}{ Lake } & \multicolumn{2}{|c|}{$\begin{array}{l}\text { Volume of water } \\
\text { (in acre-ft) }\end{array}$} & \multirow{2}{*}{$\begin{array}{c}\text { Annual } \\
\text { local } \\
\text { inflow } \\
\text { (in acre- } \\
\text { ft) }\end{array}$} & \multicolumn{2}{|c|}{$\begin{array}{l}\text { Net evaporation } \\
\text { (in acre-ft) }\end{array}$} & \multirow{2}{*}{$\begin{array}{l}\text { Water } \\
\text { required } \\
\text { to fill } \\
\text { lake (in } \\
\text { acre-ft) }\end{array}$} & \multirow{2}{*}{$\begin{array}{c}\text { Years } \\
\text { required } \\
\text { to fill } \\
\text { lake }\end{array}$} \\
\hline & Sept. 1952 & $\begin{array}{l}\text { At alti- } \\
\text { tude of } \\
1,425 \mathrm{ft}\end{array}$ & & $\begin{array}{l}\text { During } \\
\text { filling }\end{array}$ & $\begin{array}{c}\text { Annual } \\
\text { at } \\
1,425 \mathrm{ft}\end{array}$ & & \\
\hline
\end{tabular}

ANNUAL INFLOW TO DEVILS LAKE: BY DIVERSION, 180,000 ACRE-FEET AND 195,000 TONS; TOTAL INCLUDING NATURAL INFLOW, ROUNDED, 190,000 ACRE-FEET AND 200,000 TONS

\begin{tabular}{|c|c|c|c|c|c|c|c|}
\hline Devils Lake... & 130,000 & 385,000 & 12,000 & 38,000 & 32,000 & 293,000 & 1.5 \\
\hline East Bay Devils Lake........ & Negligible & 180,000 & 3,000 & 14,000 & 16,000 & 194,000 & 1. 2 \\
\hline East Devils Lake............ & 11,000 & 98,000 & 1,600 & 2,000 & 4,600 & 89,000 & .6 \\
\hline Stump Lake ....................... & 20,000 & 265,000 & 5,000 & 16,000 & 10,000 & 261,000 & 1.8 \\
\hline
\end{tabular}

ANNUAL INFLOW TO DEVILS LAKE: BY DIVERSION, 180,000 ACRE-FEET AND 125,000 TONS; TOTAL INCLUDING NATURAL INFLOW, ROUNDED, 190,000 ACRE-FEET AND 130,000 TONS

\begin{tabular}{|c|c|c|c|c|c|c|c|}
\hline Devils Lake.. & 130,000 & 385,000 & 12,000 & 38,000 & 32,000 & 293,000 & 1. 5 \\
\hline East Bay Devils Lake.... & Negligible & 180,000 & 3,000 & 14,000 & 16,000 & 194,000 & 1.2 \\
\hline East Devils Lake & 11,000 & 98,000 & 1,600 & 2,000 & 4,600 & 89,000 & .6 \\
\hline Stump Lake......... & 20,000 & 265,000 & 5,000 & 16,000 & 10,000 & 261,000 & 1.8 \\
\hline
\end{tabular}

ANNUAL INFLOW TO DEVILS LAKE: BY DIVERSION, 90,000 ACRE-FEET AND 98,000 TONS; TOTAL INCLUDING NATURAL INFLOW, ROUNDED, 100,000 ACRE-FEET AND 100,000 TONS

\begin{tabular}{|c|c|c|c|c|c|c|c|}
\hline Devils Lake.- & 130,000 & 385,000 & 12,000 & 90,000 & 32,000 & 345,000 & 3.5 \\
\hline East Bay Devils Lake. & Negligible & 180,000 & 3,000 & 35,000 & 16,000 & 215,000 & 3.0 \\
\hline East Devils Lake............ & 11,000 & 98,000 & 1,600 & 6,000 & 4,600 & 93,000 & 1. 6 \\
\hline Stump Lake. & 20,000 & 265,000 & 5,000 & 42,000 & 10,000 & 287,000 & 4. 9 \\
\hline
\end{tabular}


TABLE 15.-Summary of computations for Devils Lake and adjoining lakes of annual local inflow, net evaporation, dissolved solids, and water and years required to fill to an altitude of 1,425 feet-Continued

\begin{tabular}{|c|c|c|c|c|c|c|c|c|c|c|}
\hline \multirow{4}{*}{ Lake } & \multicolumn{10}{|c|}{ Dissolved solids } \\
\hline & \multicolumn{7}{|c|}{ Quantity ( 1,000 tons) } & \multicolumn{3}{|c|}{ Concentration (ppm) } \\
\hline & \multirow{2}{*}{$\begin{array}{c}\text { In lake } \\
\text { water } \\
\text { September } \\
1952\end{array}$} & \multirow{2}{*}{$\begin{array}{l}\text { Inflow } \\
\text { while } \\
\text { filling } \\
\text { lake }\end{array}$} & \multicolumn{2}{|c|}{$\begin{array}{l}\text { Redissolved } \\
\text { while filling }\end{array}$} & \multicolumn{2}{|c|}{$\begin{array}{l}\text { Total imme- } \\
\text { diately after } \\
\text { filling lake }\end{array}$} & \multirow{2}{*}{ Final : } & \multicolumn{2}{|c|}{$\begin{array}{l}\text { When first } \\
\text { fllled }\end{array}$} & \multirow[b]{2}{*}{ Final ${ }^{t}$} \\
\hline & & & $\begin{array}{l}\text { Prob- } \\
\text { able } \\
\text { mini- } \\
\text { mum }\end{array}$ & $\begin{array}{l}\text { Prob- } \\
\text { able } \\
\text { maxi- } \\
\text { mimm }\end{array}$ & $\begin{array}{l}\text { Prob- } \\
\text { able } \\
\text { mini- } \\
\text { mum }\end{array}$ & $\begin{array}{l}\text { Prob- } \\
\text { able } \\
\text { maxi- } \\
\text { mum }\end{array}$ & & $\begin{array}{l}\text { Prob- } \\
\text { able } \\
\text { mini- } \\
\text { mum }\end{array}$ & $\begin{array}{l}\text { Prob- } \\
\text { able } \\
\text { maxi- } \\
\text { mum }\end{array}$ & \\
\hline
\end{tabular}

ANNUAL INFLOW TO DEVILS LAKE: BY DIVERSION, 180,000 ACRE-FEET AND 195,000 TONS TOTAL INCLUDING NATURAL INFLOW, ROUNDED, 190,000 ACRE-FEET ANI 200,000 TONS

\begin{tabular}{|c|c|c|c|c|c|c|c|c|c|c|}
\hline Devils Lake... & 1,500 & 300 & 200 & 500 & 2,000 & 2,300 & 480 & 3,800 & 4,400 & 920 \\
\hline East Bay Devils & Negligible & $850-950$ & 250 & 800 & 1,100 & 1,800 & 240 & & 7,400 & 1,000 \\
\hline East Devils Lake... & $\begin{array}{r}730 \\
78+10\end{array}$ & $500-800$ & 150 & 450 & 1,400 & 2,000 & 140 & 10,500 & 15,000 & 1,020 \\
\hline Stump Lake .......... & 1,600 & $2,000-2,800$ & 300 & 1,100 & 3,900 & 5,500 & 380 & 10,800 & 15,300 & 1,060 \\
\hline
\end{tabular}

ANNUAL INFLOW TO DEVILS LAKE: BY DIVERSION, 180,000 ACRE-FEET AND 125,000 TONS TOTAL INCLUDING NATURAL INFLOW, ROUNDED, 190,000 ACRE-FEET AND 130,000 TONS

\begin{tabular}{|c|c|c|c|c|c|c|c|c|c|c|}
\hline Devils Lake & 1,500 & 195 & 200 & 500 & 1,900 & 2,200 & 310 & 3,600 & 4,200 & 600 \\
\hline $\begin{array}{l}\text { East Bay Devils } \\
\text { Lake }\end{array}$ & Negligible & $750-900$ & 250 & 800 & 1,000 & 1,700 & 160 & 4,100 & 6,900 & 650 \\
\hline East Devils Lake.... & 730 & $450-750$ & 150 & 450 & 1,300 & 1,900 & 90 & 9,800 & 14,300 & 660 \\
\hline Stump Lake. ........ & 1,600 & $1,900-2,700$ & 300 & 1,100 & 3,800 & 5,400 & 250 & 10,500 & 15,000 & 690 \\
\hline
\end{tabular}

ANNUAL INFLOW TO DEVILS LAKE: BY DIVERSION, 90,000 ACRE-FEET AND 98,000 TONS TOTAL INCLUDING NATURAL INFLOW, ROUNDED, 100,000 ACRE-FEET AND 100,000 TONS

\begin{tabular}{|c|c|c|c|c|c|c|c|c|c|c|}
\hline Devils Lake. & 1,500 & 350 & 200 & 500 & 2,000 & 2,400 & 550 & 3,800 & 4,600 & 1,050 \\
\hline East Bay Devils & & & & & & & & & & \\
\hline East Devils Lake... & 730 & $\begin{array}{l}50-1,100 \\
550-850\end{array}$ & $\begin{array}{l}250 \\
150\end{array}$ & $\begin{array}{l}800 \\
450\end{array}$ & $\begin{array}{l}1,200 \\
1,400\end{array}$ & $\begin{array}{l}1,900 \\
2,000\end{array}$ & $\begin{array}{l}320 \\
180\end{array}$ & $\begin{array}{r}4,900 \\
10,500\end{array}$ & $\begin{array}{r}7,800 \\
15,000\end{array}$ & $\begin{array}{l}1,290 \\
1,360\end{array}$ \\
\hline Stump Lake......... & 1,600 & $2,200-3,000$ & 300 & 1,100 & 4,100 & 5,700 & 540 & 11,400 & 15,800 & 1,500 \\
\hline
\end{tabular}

1 Final tonnages and concentrations are those at which the outflow of dissolved solids equals the inflow and the concentrations in the lakes no longer decrease.

\section{EAST BAY DEVILS IAKE}

The East Bay Devils Lake is here considered to include all the lake area between State Route 20 south of Fort Totten Station and the northwest end of East Devils Lake (pl. 1). Although East Bay Devils Lake once was a large lake and had a very long shoreline, during the past 20 years it has usually been a dry lakebed, except for Black Tiger Bay and a few small marshes. In 1950 several square miles of the lakebed were covered with shallow water from local inflow. By May 1952 the only appreciable area of water surface was in Black Tiger Bay.

The small amount of information on the concentration and tonnages of dissolved solids in East Bay Devils Lake is summarized in table 16. 


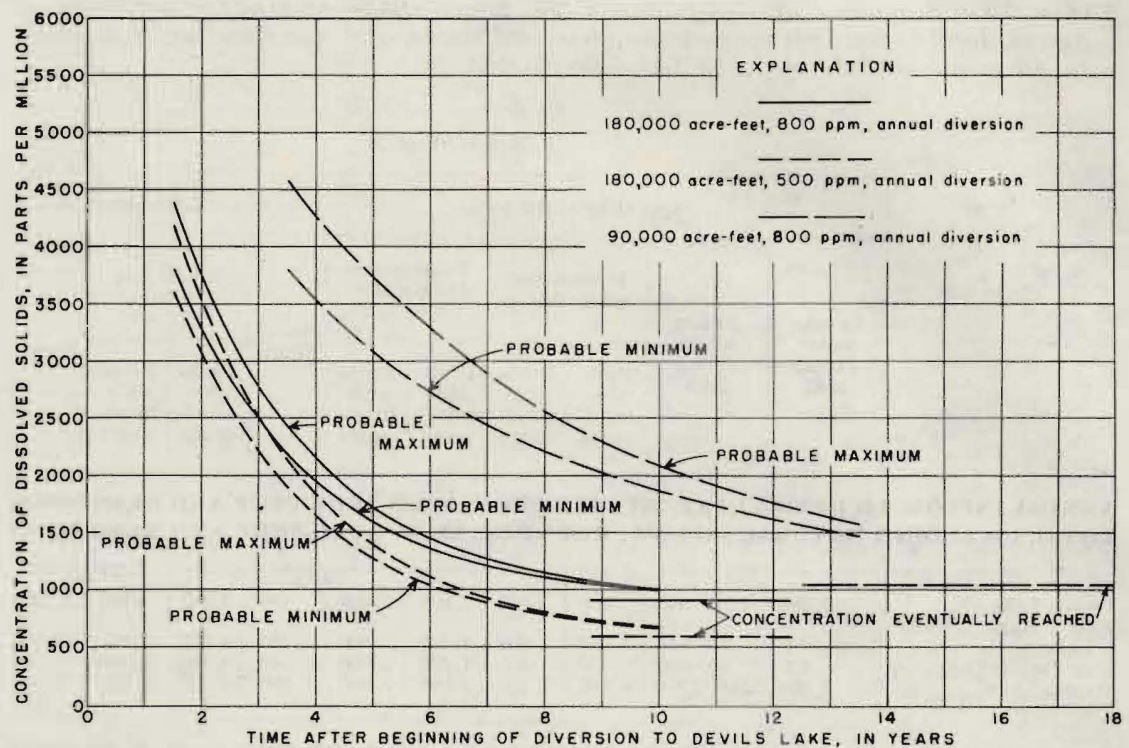

Figure 21.-Computed progressive decrease in concentrations of dissolved solids in Devils Lake after filling to 1,425 feet.

TABLE 16.-Approximate volumes of water and tonnages of dissolved solids in East Bay Devils Lake

[A, Young (1924); B, Babcock (1903); and C, Pope (1909. p. 15)]

\begin{tabular}{|c|c|c|c|c|c|}
\hline \multirow{2}{*}{ Date } & \multirow{2}{*}{ Altitude (ft) } & \multirow{2}{*}{$\begin{array}{l}\text { Volume of } \\
\text { water } \\
\text { (acre-ft) }\end{array}$} & \multicolumn{2}{|c|}{ Dissolved solids } & \multirow{2}{*}{$\begin{array}{c}\text { Source of } \\
\text { concentration } \\
\text { information }\end{array}$} \\
\hline & & & $\begin{array}{c}\text { Concentration } \\
(\mathrm{ppm})\end{array}$ & $\begin{array}{l}\text { Quantity } \\
\text { (tons) }\end{array}$ & \\
\hline $\begin{array}{l}1899 \ldots \ldots \\
1902 \ldots \\
1907 \ldots \ldots \\
1919 \ldots \ldots \\
1920 \ldots \ldots\end{array}$ & $\begin{array}{r}1,424.6 \\
1,425.2 \\
1,423.6\end{array}$ & $\begin{array}{r}174,000 \\
183,000 \\
159,000 \\
\end{array}$ & $\begin{array}{r}18,471 \\
10,874 \\
11,755 \\
137,801 \\
162,929\end{array}$ & $\begin{array}{l}1,990,000 \\
2,690,000 \\
2,520,000\end{array}$ & $\begin{array}{l}\mathrm{A} \\
\mathrm{B} \\
\mathrm{C} \\
\mathrm{A} \\
\mathrm{A}\end{array}$ \\
\hline
\end{tabular}

${ }^{1}$ Residue on evaporation at $150^{\circ} \mathrm{C}$.

The altitudes of the lake surface as given through 1907 are assumed to be equal to those for Devils Lake and are approximate only. The channel between Devils Lake and East Bay Devils Lake was probably effective in equalizing the water surface during those years. Also in 1899 and 1902 the mixing between the two bodies of water was assumed to be sufficient to maintain approximately equal concentrations in each. Hence, the concentrations of samples that were taken presumably from main Devils Lake were assumed to equal the concentrations in East Bay Devils Lake. In 1907 the concentration of 
dissolved solids in East Bay Devils Lake was found to be 11,755 ppm as compared with 9,448 ppm in Devils Lake. By 1919 and 1920 the concentrations in East Bay Devils Lake were much higher than those in Devils Lake. Probably after about 1917 the flow out of Devils Lake was very small and was entirely insufficient to replace the net losses of water from East Bay Devils Lake. Information given by Pope $(1909$, p. 6) indicates that outflow from Devils Lake would cease at an altitude of about 1,418 feet above mean sea level, datum of 1929.

In 1907 about 2.5 million tons of dissolved solids was in the water of East Bay Devils Lake. Outflow to East Devils Lake from East Bay Devils Lake probably ended about 1907 . Between approximately 1907 and 1917 some dissolved solids must have been discharged into East Bay Devils Lake with the outflow from Devils Lake. Available data thus indicate that probably more than 2.5 million tons of dissolved solids must have been precipitated from the water while East Bay Devils Lake was drying up. During the many years that it was nearly dry, much of the total quantity of salts may have been blown away with the dust from the dry lakebed. On the basis of the small amount of salts that were redissolved when Devils Lake rose 10 feet, the net tonnage of salts that will go into solution if East Bay Devils Lake is restored to 1,425 feet is assumed to be from 250,000 to 800,000 tons.

The capacity of East Bay Devils Lake at an altitude of 1,425 feet is about 180,000 acre-feet (fig. 16). Perhaps an average of about 12,000 acre-feet per year would be required to replace net evaporation while the bay was filling. The time required to fill East Bay Devils Lake is computed to be 1.2 years for an annual rate of diversion to Devils Lake of 180,000 acre-feet and 3.0 years for a rate of 90,000 acre-feet. A reduction of 50 percent in rate of diversion more than doubles the time required to fill the bay because the net evaporation from East Bay Devils Lake and from Devils Lake exceeds the natural inflow to them and the net loss is relatively independent of the rate of diversion to Devils Lake.

Evaporation from East Bay Devils Lake at an altitude of 1,425 feet would be about 16,000 acre-feet per year more than precipitation on the water surface. Average annual inflow from the surrounding drainage area (exclusive of the area tributary to main Devils Lake) is estimated to average 3,000 acre-feet. Net water loss from East Bay Devils Lake would thus be about 13,000 acre-feet annually.

Estimated tonnages of dissolved solids and corresponding concentrations when the bay is first filled are shown in table 15. This table summarizes the computations of quantities of water and dissolved solids, the computed dissolved-solids concentrations, and some $326053-55-6$ 
of the assumptions and estimates on which the computations are based. The computed initial tonnages range from about 1 million to 1.9 million tons for the different assumptions and are changed only a little by the different assumed rates of diversion to Devils Lake and the different assumed concentrations in the diverted water.

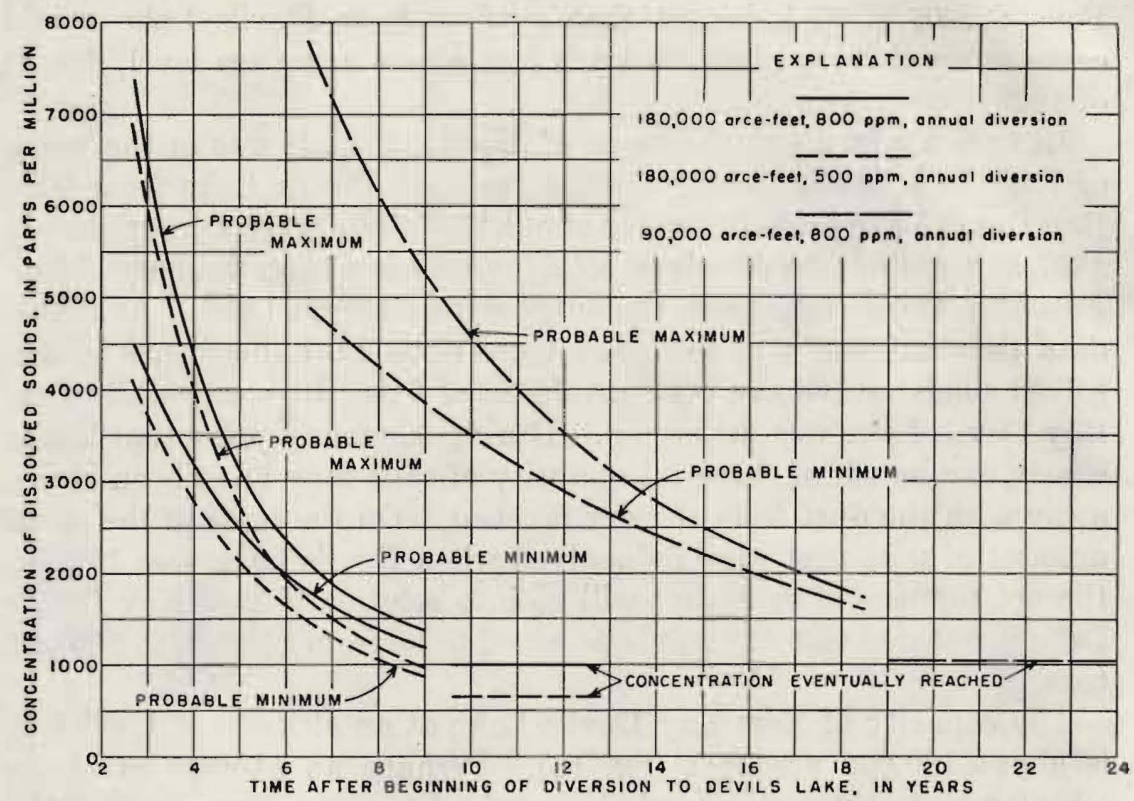

Figure 22.-Computed progressive decrease in concentrations of dissolved solids in East Bay Devils Lake after filling to 1,425 feet.

Computed changes in concentration of dissolved solids in East Bay Devils Lake are shown on figure 22. Concentrations immediately after the bay is filled are estimated to be between a probable minimum of $4,100 \mathrm{ppm}$ and a probable maximum of $7,800 \mathrm{ppm}$. The concentration in East Bay Devils Lake decreases faster as the assumed concentration in the inflow to Devils Lake is reduced and becomes even more rapid as the assumed rate of diversion to Devils Lake is increased.

\section{EAST DEVILS LAKE}

Flow out of East Bay Devils Lake into East Devils Lake probably ended some time about 1907. The altitude of Devils Lake in 1907 was about 1,423.6 feet, the average of the highest and lowest observed altitudes for the year. If the altitude of East Devils Lake is assumed to have been the same as Devils Lake, the volume of water in East Devils Lake would have been about 92,000 acre-feet. Pope (1909, p. 7) reported a density of 1.008 (equivalent to about $13,000 \mathrm{ppm}$ ) for 
the water in East Devils Lake in 1907. For 1919 and 1920, concentrations of dissolved solids are available, but the altitude of the lake surface in those years is not known. This information and additional data for recent years are listed in table 17.

TABLE 17.-Approximate volumes of water and tonnages of dissolved solids in East Devils Lake

[A, Pope (1909, p. 15); B, Young (1924); C, U. S. Geol. Survey, Lincoln, Nebr]

\begin{tabular}{|c|c|c|c|c|c|c|}
\hline \multirow{2}{*}{ Date } & \multirow{2}{*}{$\begin{array}{c}\text { Number } \\
\text { of } \\
\text { samples }\end{array}$} & \multirow{2}{*}{$\begin{array}{l}\text { Altitude } \\
\text { (ft) }\end{array}$} & \multirow{2}{*}{$\begin{array}{l}\text { Volume of } \\
\text { water } \\
\text { (acre-ft) }\end{array}$} & \multicolumn{2}{|c|}{ Dissolved solids } & \multirow{2}{*}{$\begin{array}{c}\text { Source of } \\
\text { concentra- } \\
\text { tion } \\
\text { information }\end{array}$} \\
\hline & & & & $\begin{array}{c}\text { Concentration } \\
\text { (ppm) }\end{array}$ & $\begin{array}{l}\text { Quantity } \\
\text { (tons) }\end{array}$ & \\
\hline $1907 \ldots$ & 1 & $1,423.6 \pm$ & 92,000 & $13,000 \pm$ & $1,600,000$ & A \\
\hline 1919 & 1 & & & 114,932 & $-\ldots-1, \ldots$ & B \\
\hline June $18,1949 \ldots$ & 6 & $1,402.5 \pm$ & 12,400 & 41,100 & 693,000 & C \\
\hline Aug. 1, 1950_.. & 2 & $\ldots \ldots$ & $\ldots \ldots$ & 35,300 & $\ldots \ldots$ & C \\
\hline Oct. 6,1951 & 1 & & & 140,100 & & C \\
\hline Mar. 28, 1952 & 1 & $1,403.5$ & & ${ }^{1} 62,000$ & & $\mathrm{C}$ \\
\hline May 14,1952 & 2 & $1,403.0$ & 13,800 & 38,800 & 728,000 & C \\
\hline Oet. 2,1952 & 1 & $1,401.9$ & 10,600 & ${ }^{1} 52,600$ & 758,000 & $\mathrm{C}$ \\
\hline
\end{tabular}

1 Residue on evaporation at $180^{\circ} \mathrm{C}$.

The high concentration of March 28, 1952, was caused by thick ice on the lake. The altitude for June 18, 1949, is based on a comparison of soundings for that date with soundings for May 14, 1952.

Table 17 indicates that the present quantity of dissolved solids is about 730,000 tons. This is less than half the tonnage as shown by the small amount of information available for 1907. According to this table, the dissolved solids lost from the lake water during the 20 -foot fall in lake level amounted to about 900,000 tons. If the lake level were raised to 1,425 feet, the probable quantity of salts that might be redissolved is estimated to be from 150,000 tons to 450,000 tons.

At an altitude of 1,425 feet, East Devils Lake has a capacity of 98,000 acre-feet (fig. 17). This capacity exceeds the volume of water in the lake during September 1952 by about 87,000 acre-feet. Evaporation during filling would probably exceed precipitation on the lake surface and local inflow by only 1,000 to 2,000 acre-feet annually. The computed inflow to East Devils Lake from East Bay Devils Lake is 147,000 acre-feet per year for an assumed diversion to Devils Lake of 180,000 acre-feet and is 57,000 acre-feet per year for an assumed annual diversion of 90,000 acre-feet. If these annual inflows are at a uniform rate, 0.6 and 1.6 years, respectively, are required to fill East Devils Lake to 1,425 feet. 'The estimated probable quantities of dissolved solids in the lake immediately after filling range from 1.3 million to 2 million tons. The corresponding concentrations are 
9,800 and $15,000 \mathrm{ppm}$. These initial concentrations do not vary significantly with the assumed changes in rates and concentrations of the water that is diverted into Devils Lake. Table 15 contains information based on the assumptions and the results of computations. Figure 23 shows the computed changes in probable minimum and maximum concentrations of dissolved solids in East Devils Lake for the assumed combinations of rate of diversion and concentration in the water that is diverted to Devils Lake.

\section{STUMP LAKE}

Although for the past several years a roadway has divided Stump Lake into east and west parts, the two lakes once formed one large and irregular lake. At the present time (1953) water would flow out of west Stump into east Stump Lake through three 2-foot culverts if the altitude of the surface of west Stump Lake reaches about 1,400 feet. At an altitude a few feet higher, the roadway would be overflowed. If Stump Lake is filled to an altitude of 1,425 feet, west Stump and east Stump will join at an altitude of about 1,404 feet and will then fill as one lake.

Overflow from East Devils Lake to Stump Lake ended when Devils Lake (and East Devils Lake which was then a bay) fell a little below 1,450 feet. The overflow ceased considerably before 1867, the year in which lake levels were first recorded. Since outflow from East Devils Lake ended, Stump Lake has received only local inflow from a drainage area of perhaps 400 square miles.

Little is definitely known either about the volumes of water or about the concentrations of dissolved solids in Stump Lake during the past years. Simpson (1912, p. 122-123, 139) reported that the area of Stump Lake in 1883 was about 16 square miles and that the maximum depth as measured in 1911 was 39 feet. This maximum depth seems to be inconsistent with other information that he gives. However, a maximum depth of 39 feet above the present lake bottom would require an altitude of water surface of about 1,418 feet. At this altitude the surface area would have been about 14 square miles. If 1,418 feet can be assumed to be approximately the lake level in both 1911 and 1912, the volume of water would have been about 202,000 acre-feet. (See figs. 18 and 19.) The dissolved solids concentration in 1912 has been given by Young (1924) as 19,000 $\mathrm{ppm}$. The indicated quantity of dissolved solids would be 5.2 million tons. This figure may be far from correct if the sounding of 39 feet is not an accurate maximum depth for 1911. Information on the dissolved-solids content of the two parts of Stump Lake during recent years is shown in table 18 . The altitudes of the water surfaces on June 16, 1949, were estimated by comparison of soundings that 


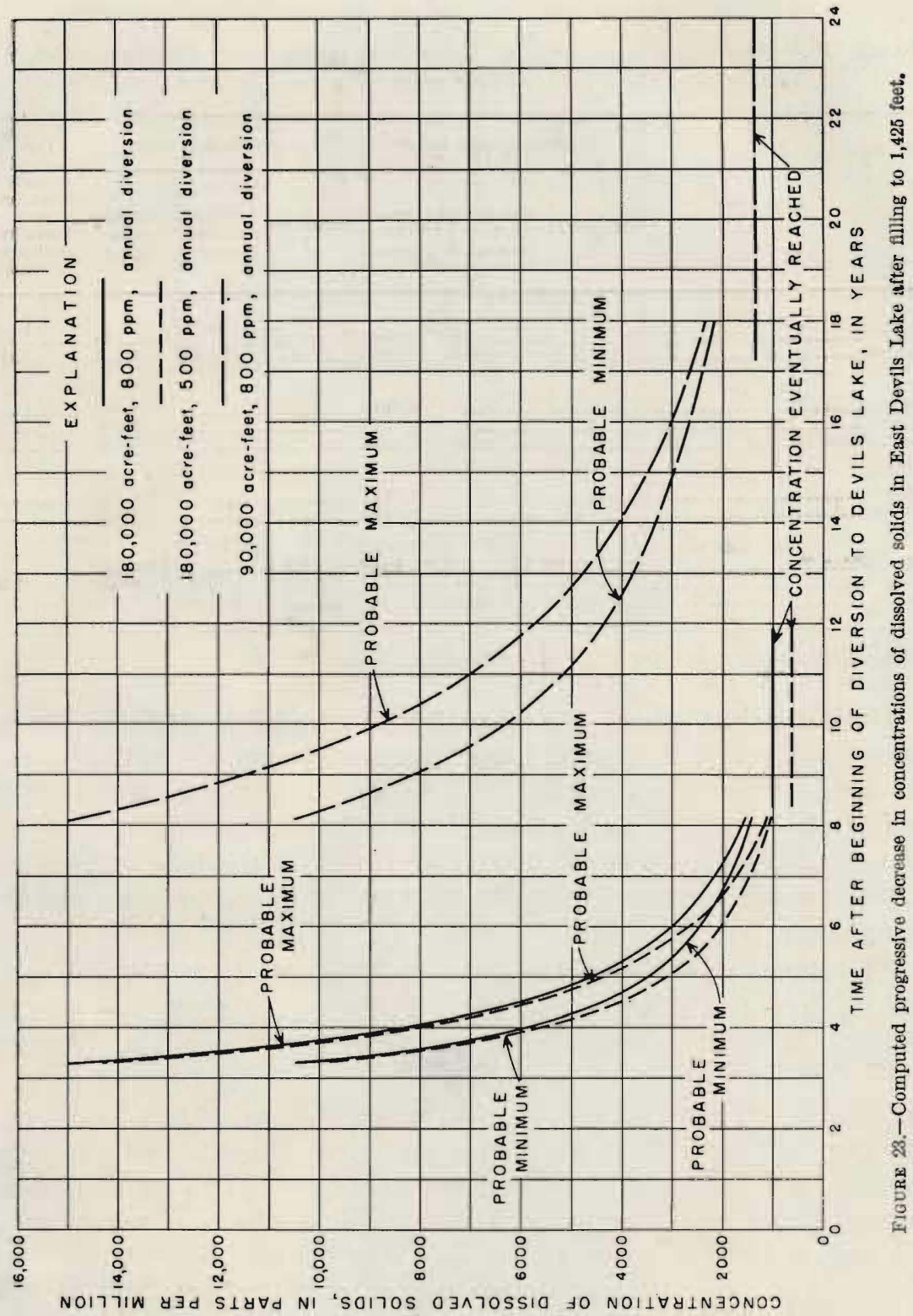


were made then with soundings that were made in May 1952. The lake levels are known for March 29, 1952, but ice on the lake considerably reduced the volume of water that contained dissolved solids at the sampled concentration.

TABLE 18.-Approximate volumes of water and tonnages of dissolved solids in Stump Lake

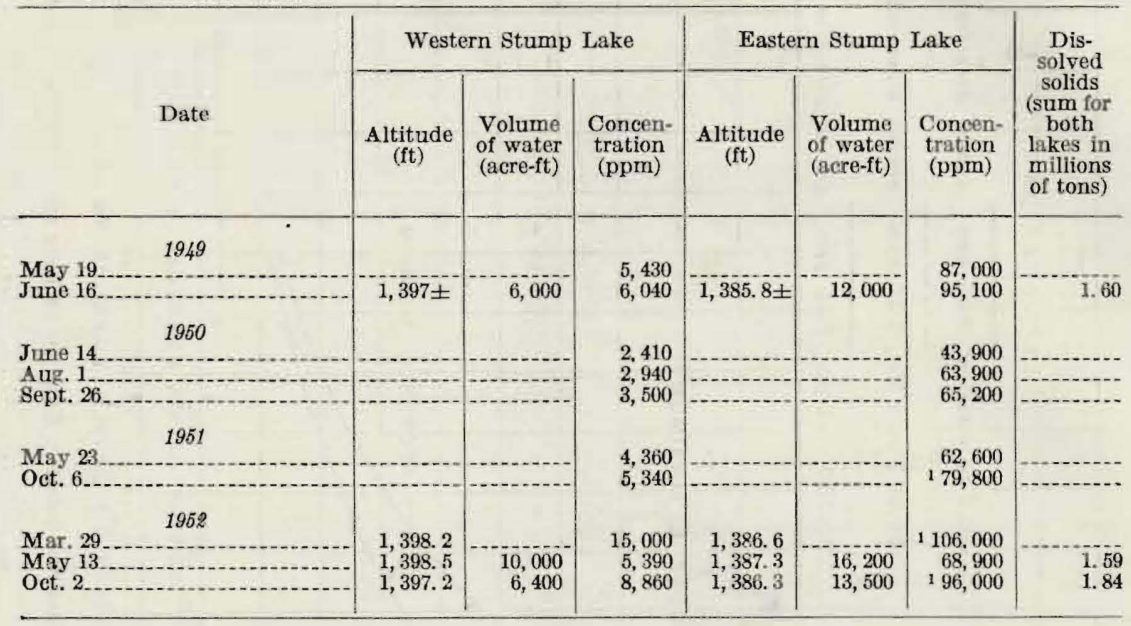

1 Residue on evaporation at $180^{\circ} \mathrm{C}$.

During recent years, the quantity of dissolved solids in the 2 lakes that comprise Stump Lake has been about 1.6 million tons. Available information, which may be inaccurate, indicates that 3 million to 4 million tons of dissolved solids disappeared from the waters of the lake between 1912 and 1949. If the lake is filled to 1,425 feet, an estimated 300,000 to $1,100,000$ tons of salts will be redissolved.

The capacity of Stump Lake at an altitude of 1,425 feet is about 265,000 acre-feet (figs. 18 and 19). At the end of 1952, the volume of water in the 2 separated lakes was about 20,000 acre-feet. As the area of Stump Lake is 15 square miles at an altitude of 1,425 feet, the estimated annual net evaporation when full is 10,000 acre-feet. Average annual inflow from drainage areas directly tributary to Stump Lake is estimated to be 5,000 acre-feet. With an allowance for net losses from Stump Lake during filling, the time required to fill Stump Lake is computed to be 1.8 years and 4.9 years. The shorter time is for the computed rate of outflow from East Devils Lake to Stump Lake of 144,000 acre-feet per year; the longer time is for the computed rate of 54,000 acre-feet per year. These computed rates of flow into Stump Lake correspond to assumed annual 
rates of diversion to Devils Lake of 180,000 acre-feet and 90,000 acre-feet, respectively.

Quantities of dissolved solids in Stump Lake when it is first filled are estimated at a probable minimum of 3.8 million to 4.1 million tons and a probable maximum of 5.4 million to 5.7 million tons. Computed concentrations of dissolved solids in Stump Lake when first filled are 10,500 to $15,800 \mathrm{ppm}$. The estimates and the computed concentrations and tonnages are listed in table 15 . Figure 24 shows the computed decrease in concentrations in the lake with time. The time required for the concentration in the lake to decrease to $5,000 \mathrm{ppm}$, which is the concentration the Fish and Wildlife Service (written communication) has suggested as the probable maximum for fish life, ranges from 2 to 9 years after Stump Lake is filled. The wide range in time is due to differences in the assumptions that were made as the basis for the computations. The effect of rate of inflow to Devils Lake is one of the most significant factors that affect the time for the concentrations to decrease to any particular figure.

\section{DISCHARGE INTO THE SHEYENNE RIVER}

Concentrations in Stump Lake cannot decrease after the lake is filled to a given level unless water can flow from the lake. Although many years ago the overflow from Stump Lake did enter the Sheyenne River near the present town of Tolna, N. Dak., the overflow ended at an altitude of about 1,460 feet. Now an artificial channel would be required to drain Stump Lake into the Sheyenne River.

Overflow to the Sheyenne River is computed to start about 5 years after the beginning of diversion to Devils Lake at a rate of 180,000 acre-feet per year or 13 years after the beginning of diversion at 90,000 acre-feet per year. When overflow begins, the total quantity of dissolved solids in all the lakes from Devils Lake to Stump Lake might be as much as 8 million tons and probably would not be less than 5.4 million tons. These total tonnages are the rounded sums of the tonnages of dissolved solids now in the lakes plus estimated salts redissolved during filling plus dissolved solids in Devils Lake inflow during filling.

The concentration of dissolved solids in Stump Lake should eventually approach about 1,000 to $1,500 \mathrm{ppm}$ according to the assumptions and computations. However, the concentration when overflow first begins is likely to be 10,000 to $16,000 \mathrm{ppm}$. Concentrations would remain high for several years after overflow started (fig. 24). The effect of these relatively large quantities of water with high concentrations of dissolved solids probably would be harmful downstream from their point of entry into the Sheyenne River. 


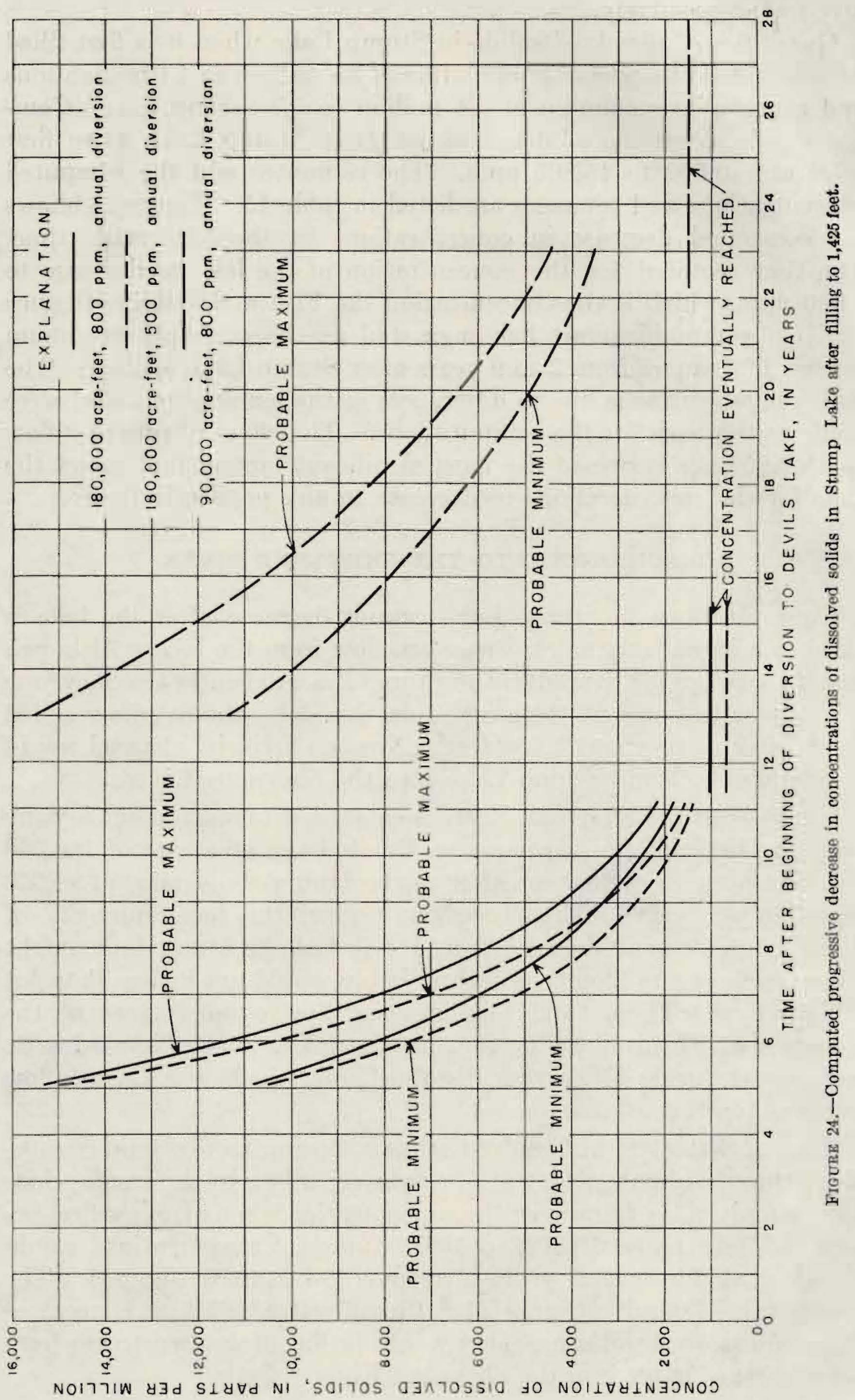




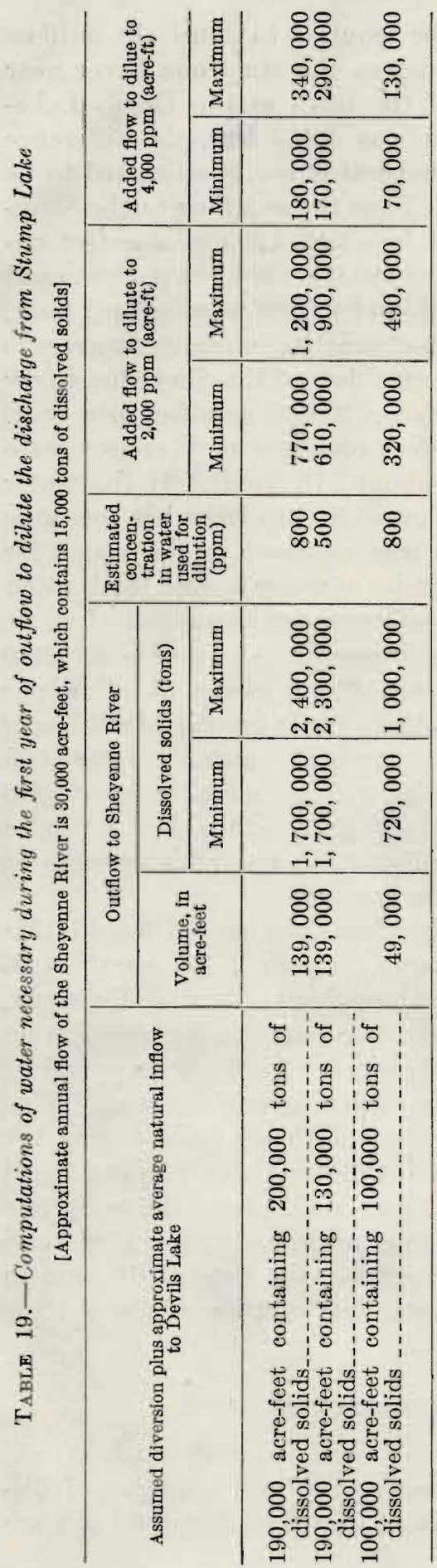


The amount of water that would be required to dilute the outflow of Stump Lake to given concentrations in the Sheyenne River near Tolna can be readily computed. If the lakes of the Devils LakeStump Lake chain were at an altitude of 1,425 feet, the difference between average losses and average natural inflow is estimated to be 41,000 acre-feet per year (table 15). Thus the overflow to the Sheyenne River from Stump Lake should be about 139,000 acre-feet annually for a diversion to Devils Lake of 180,000 acre-feet per year and 49,000 acre-feet annually for a diversion of 90,000 acre-feet per year. These annual rates of outflow to the Sheyenne River represent average rates of flow of 192 and $68 \mathrm{cfs}$. Average flow of the Sheyenne River near Tolna is probably about $40 \mathrm{cfs}$ or 30,000 acre-feet per year. Dissolved solids in this 30,000 acre-feet of water may approximate 15,000 tons (average concentration about $370 \mathrm{ppm}$ ). If the water that is available for diluting the outflow of Stump Lake has the same concentration of dissolved solids as was assumed in the water for filling the lake, the approximate quantities of water needed for dilution would be as shown in table 19 . These computed quantities of water during the first year of outflow from Stump Lake range from 70,000 acre-feet for the probable minimum $(100,000$ acre-feet of inflow per year to Devils Lake and a concentration of $800 \mathrm{ppm}$ in the diluting water) to 1.2 million acre-feet for the probably maximum $(190,000$ acre-feet annual inflow to Devils Lake and a concentration of 800 $\mathrm{ppm}$ ). An assumed concentration of $500 \mathrm{ppm}$ rather than $800 \mathrm{ppm}$ decreased the computed quantities of diluting water by about 5 to 25 percent for the 4 computations that were made.

These computed quantities of water that are required for dilution in the Sheyenne River are very large. (Each 1,000 acre-feet is equivalent to an average rate of $1.38 \mathrm{cfs}$ throughout a year.) Obviously, the only practical way to dilute the outflow from Stump Lake during the first few years to a reasonably satisfactory concentration would be to reduce the quantity of outflow to be diluted in any one year. This could be done by reducing the diversion to Devils Lake during the first years after Stump Lake was filled. The available water not used for diversion to Devils Lake could be released down the Sheyenne River to help dilute the flow. If possible, additional water should also be made available for dilution. Otherwise, the rate of dilution in Stump Lake might be reduced so much that dilution of the outflow would be necessary for many years.

\section{EFFECT OF CHANGES IN ASSUMPTIONS}

In this study, many assumptions have been made on which to base the computations of probable concentrations and tonnages of dissolved solids in the lakes of the Devils Lake chain if these lakes are 
filled by diversions from outside the drainage basin. The computed results should be understood as applicable only insofar as the assumptions may be good approximations of the actual quantities and hydrologic processes when and if the lakes are filled.

The assumed probable minimum and maximum quantities of salts that will be redissolved while the lakes are filling is one of the least certain estimates or assumptions. Initial concentrations in the lakes, that is, the concentrations immediately after the lakes are filled, would depend largely on the amount of salts that are redissolved as the lakes rise. In contrast, the final concentrations and tonnages in the lakes after years of diversion to Devils Lake at some constant rate would depend principally on the concentration of dissolved solids in the diverted water and on the relative quantity of diversion as compared to net losses from the lakes. At an annual rate of diversion of 180,000 acre-feet to Devils Lake, the final concentrations in the lake are about proportional to and not much greater than the concentrations of dissolved solids in the diverted flow to Devils Lake. At half this rate of diversion, the final concentration would not be greatly increased in Devils Lake, but the final concentration in Stump Lake would be increased by 40 percent. (See table 15.)

A decrease from 800 to $500 \mathrm{ppm}$ in the assumed concentration of dissolved solids in the water that is used to fill the lakes increases the rate of dilution only a little. A decrease from 180,000 to 90,000 acrefeet per year in the rate of diversion to Devils Lake more than doubles the time required for the concentration in the lakes to decrease by any given percentage.

Inaccuracies in the estimated net losses from the filled lakes would have little effect on the computed concentrations in the lakes for high rates of diversion to Devils Lake. These inaccuracies would have a rapidly increasing effect on the computed concentrations as the assumed rate of diversion is decreased and the net losses become larger and larger fractions of the diversion.

Computations were made for only one assumed altitude to which the lakes would be filled and maintained. Probably, the tonnages of salts that would redissolve would not be decreased much if the lakes were restored to a level lower than 1,425 feet nor be much increased by restoration to a higher level. The redissolved salts plus the tonnage of dissolved solids now in the lakes are much larger quantities than the dissolved solids in the diverted water that would be used to fill the lakes. Hence the initial concentrations would be greater in each lake for a level of filling lower than the assumed altitude of 1,425 feet. The rate of dilution in each lake for a given rate of diversion to Devils Lake would be somewhat faster for the lower altitudes and smaller capacities. The total quantity of dissolved solids to be flushed 
away by the Sheyenne River probably would be only a little smaller if the lakes were restored to lower levels, but for a given total water supply slightly more water would be available for flushing.

\section{POLLUTION PROBLEMS OF LAKE RESTORATION}

A report issued by the United States Public Health Service (1952, map opposite p. 38) shows that the city of Devils Lake is a major source of pollution. Untreated sewage discharged into Devils Lake by the city introduces a pollution problem in lake restoration. A uniform and adequate inflow of fresh water to the lake would be necessary to offset the oxygen requirements of organic material in the lake. A sample of bed sediment collected in Creel Bay contained 0.52 percent of organic nitrogen and thus indicates pollution of the lake.

The effects of initial discharges of polluted, brackish waters on downstream developments are not fully known. Certainly there will be some adverse effects on fish life in the Sheyenne River. If the lakes are restored, periodic checks of the quality of the water in the lower Sheyenne River would be necessary.

\section{LITERATURE CITED}

Abbott, G. A., 1924, A chemical investigation of the water of Devils Lake, North Dakota: Ind. Acad. Sci., v. 34.

Babcock, E. J., 1903, Water resources of the Devils Lake region: N. Dak. Geol. Survey 2d Bienn. Rept., 2d ed.

Clarke, F. W., 1924, The data of geochemistry: U. S. Geol. Survey Bull. 770, 5th ed.

Congressional Documents, 1944, 78th Cong. 2d sess., S. Doc. 191 (Missouri River Basin).

Daudt, H. W., 1911, N. Dak. Univ. Quart. Jour., v. 1.

Horton, A. H., Chandler, E. F., and Bolster, R. H., 1910, Surface water supply of the United States, 1907-8: U. S. Geol. Survey Water-Supply Paper 245.

Horton, R. E., 1943, Evaporation maps of the United States: Am. Geophys. Union Trans., pt. 2.

Meyer, A. F., 1928, The elements of hydrology: 2d ed. revised, New York, John Wiley \& Sons, Inc.

North Dakota State Engineer, 1944, 4th Bienn. Rept. of State Water Conservation Commission and 21st Bienn. Rept. of State Engineer of North Dakota.

Pope, T. E. B., 1909, Devils Lake, North Dakota, A Study of physical and biological conditions, with a view to the acclimatization of fish, U. S. Bur. of Fisheries Doc. 634, in Bowers, G. M., The commissioner of fisheries for the fiscal year 1907 and special papers.

Rankama, Kalervo, and Sahama, T. G., 1950, Geochemistry: Univ. of Chicago Press. 
Simpson, H. E., 1912, Physiography of the Devils-Stump Lake region of North Dakota: N. Dak. Geol. Survey 6th Bienn. Rept.

1929, Geology and ground-water resources of North Dakota: U. S. Geol. Survey Water-Supply Paper 598.

Upham, Warren, 1895, The glacial Lake Agassiz: U. S. Geol. Survey Mon. 25.

United States Bureau of Reclamation, 1953, Proposed diversion point for North Dakota lands: Missouri-Souris Division.

United States Geological Survey, 1952, Surface water supply of the United States, 1949-50: U. S. Geol. Survey Water-Supply Paper 1175.

United States Public Health Service, 1952, Missouri-Souris development area water pollution investigation: Cooperative State and Federal Rept., Water Pollution Ser. no. 32.

Young, R. T., 1924, The life of Devils Lake, North Dakota: N. Dak. Biol. Sta. 



\section{INDEX}

\begin{tabular}{|c|c|}
\hline Page & 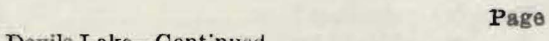 \\
\hline bott, G. A., on solubilities of salts $\ldots \ldots \ldots 3,26$ & Devils Lake - Continued \\
\hline 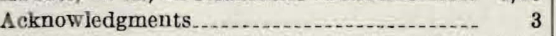 & dissolved solids in ..... \\
\hline Alkalinity & evaporation ................... \\
\hline Altitude of lakes when restored............. 56 & fluctuation of \\
\hline Analyses, chemical, of water in Devils Lake & $4,20-21,62-63$ \\
\hline basin & outflow _._._. 4,63 \\
\hline Cranberry Lake. & 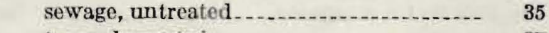 \\
\hline Devils Lake...... & 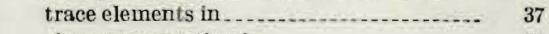 \\
\hline East Devils Lake & zinc concentration in \\
\hline Mauvais Coulee & Dissolved solids in lake waters.............. $27,52-78$ \\
\hline Mission Bay ................ & assumptions, effect of ehanges in \\
\hline Sheyenne River & Devils Lake................................... 60-65 \\
\hline Sixmile Bay........... 42 & evaporation........................ \\
\hline Stump Lake...................... & inflow to ........................... $62-63$ \\
\hline Wood Lake-_............................. & $\begin{array}{rr}\quad & 63 \\
\text { East Bay Devils Lake } & 65-68\end{array}$ \\
\hline bliography... & 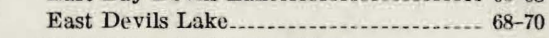 \\
\hline $\begin{array}{l}\text { Chemical and physical properties of lake } \\
\text { waters }\end{array}$ & $\begin{array}{l}\text { loss of to ground-water storage } \ldots . . . . . . . .25 \\
\text { precipitation of }\end{array}$ \\
\hline Devils Lake & Stump Lake \\
\hline $1948-52 \ldots \ldots$ & Dive:sion of water from Garrison Reservoir... 3 \\
\hline analyses of & Missouri River_..................... 2, 58-59 \\
\hline composition of & Drainage basin \\
\hline (n) & climate.......... \\
\hline er discharge & description of \\
\hline fide in & physiography and drainage............. \\
\hline 35 & recreation in \\
\hline 37 & transportation $\ldots \ldots \ldots \ldots \ldots \ldots$ \\
\hline zinc esncentration in ..... & \\
\hline
\end{tabular}

East Bay Devils Lake _.................... 40-43

East Devils Lake............................. 43-45, 46

east Stump Lake .......................... 48-50

Mauvais Coulee 28,31

miscellaneous lakes_...................... $50-52$

Mission Bay ............................... 42, 43

preliminary considerations................ 24-27

Sheyenne River....................... 52, 53-55

Silver Lake_............................... 28

Sixmile Bay _............................... 40

Sweetwater group .............. 27-28

west Stump Lake ........................ 45-48

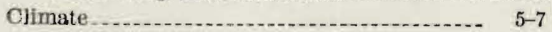

Cramberry Lake_........................ 49,51

Daudt, H. W., quoted. 40

Density of water in Devils Lake............ 34-35

East Devils Lake_........................ 43,45

east Stump Lake............................. 48

west Stump Lake....................... 48

Devils Lake, altitudes of observed........ 9 chemical and physical properties of, 1948-

$52 \ldots \ldots+33-40$

composition of, percent_............... 34, 40

density and size of sediment in ....... $\quad 37$

density of water in ................. 34-35

floor

fluctuation of ................................. 38

ground-water discharge ................ 4, 49

hydrogen sulfide in ................... 35
East Bay Devils Lake, chemical and physical properties of ... _.................. 40-43 dissolved solids in . ........................ 65-68 evaporation from ........................... 67

East Devils Lake, chemical and physical properties of . . .

density and size of sediments in .......... 45

density of water in ........................ 45

dissolved solids in ........................ 68-70

inflow to .................................. 69

outflow from . . .

Eastern Stump Lake, chemical and physical properties of ................... 46, 48-51 density and size of sediments in ........... $\quad 49$ density of water in ........................... 48

Evaporation (see also names of lakes)_12, 15, 23, 57, 63 boiling, results of ........................ 25 encentration of salts through ............. 26 Devils Lake ................ 10-12, 18, 22, 23, 24, 30 East Bay Devils Lake.................... 67

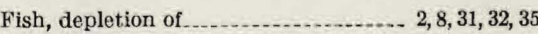

Fluctuations of Devils Lake.................. 8-24 hydrology ................................. 9-24 evaporation ............ 10-12, 18, 22, 23, 24, 30 infow to lakes ......................... 15-24 precipitation _............ 5-7, 10, 18, 23, 24, 37 runoff ....................... 12-15, 17, 22, 24 reasons for, suggested..................... 8-9 


\begin{tabular}{|c|c|}
\hline age & $\mathbf{P a}$ \\
\hline Garrison Reservoir, diversion of water from.- & Recreation . \\
\hline Ground-water discharge, Devils Lake......... & Restoration of lakes .................... \\
\hline Ground-water storage, changes in & $12-17,22,24$ \\
\hline loss of dissolved sollds to & Salts. \\
\hline umidity in drainage bastn & $36,39,40,43,45-46,48$, \\
\hline Hydrogen sulfide in Devils Lake............... & Sediments, density and size of in Devils Lake. \\
\hline ydrology of Devils Lake..................... 9-24 & East Devils Lake.................. \\
\hline evaporation & east Stump Lake.... \\
\hline $15-24$ & , in Devils Lake_............ 36, 78 \\
\hline $\begin{array}{r}19,23 \\
8,23,24,37\end{array}$ & emical and physies \\
\hline ted. & olved solids into \\
\hline $12-15,17,22,24$ & $\begin{array}{l}\text { Silver Lake, chemical and physical properties } \\
\text { of }\end{array}$ \\
\hline $\begin{array}{l}\text { flow to lakes } \\
\text { Devils Lake }\end{array}$ & cal and physical properties \\
\hline ils Lake_...................... 69 & $0,18,23,24,28,37$ \\
\hline Lake_................................. & perties of _ $\quad 39$ \\
\hline 2 & Streamflor \\
\hline $\begin{array}{l}\text { ulee, chemical and physical } \\
\text { coperties of }\end{array}$ & $\begin{array}{l}\text { Stump Lake, dissolved solids in (see also } \\
\text { Eastern and Western Stump } \\
\text { Lake). }\end{array}$ \\
\hline cal and physical properties & to group \\
\hline & roperties of \\
\hline $2 t$ & $5,15,16,21,23$ \\
\hline 63 & in \\
\hline (1) & e \\
\hline $\begin{array}{r}\text { Physical prop } \\
\text { ca } \\
\text { w }\end{array}$ & finition chemical and physical \\
\hline & -48 \\
\hline & 48 \\
\hline (n) & 亦 \\
\hline $4,16,18,23,24,28,3$ & Winds, prevailing, in drainage basin \\
\hline 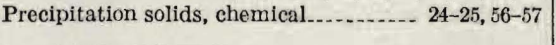 & 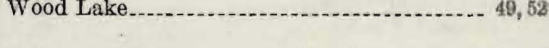 \\
\hline & \\
\hline
\end{tabular}


